\title{
U.S. GEOLOGICAL SURVEY
}

Open-File Report 91-238

Prepared as part of the

TOXIC WASTE--GROUND-WATER

CONTAMINATION PROGRAM,

U.S. GEOLOGICAL SURVEY

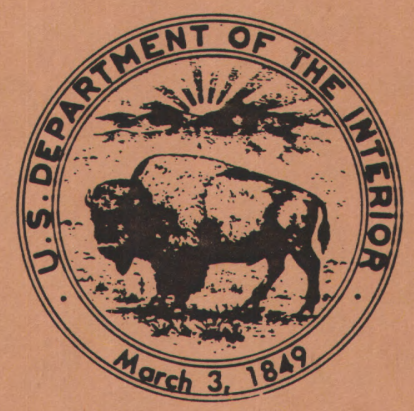




\section{ASSESSMENT OF NONPOINT-SOURCE CONTAMINATION OF THE HIGH PLAINS AQUIFER IN SOUTH-CENTRAL KANSAS, 1987}

By John O. Helgesen, Lloyd E. Stullken, and A.T. Rutledge

U.S. GEOLOGICAL SURVEY

Open-File Report 91-238

Prepared as part of the

TOXIC WASTE--GROUND-WATER

CONTAMINATION PROGRAM, U.S. GEOLOGICAL SURVEY

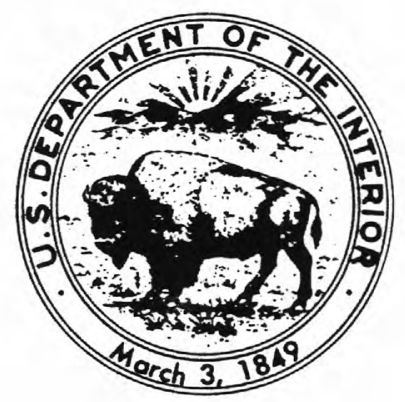


U.S. DEPARTMENT OF THE INTERIOR

MANUEL LUJAN, JR., Secretary

U.S. GEOLOGICAL SURVEY

Dallas L. Peck, Director

For additional information write to:

Copies of this report can be purchased from:

District Chief

U.S. Geological Survey

Water Resources Division

4821 Quail Crest Place

Lawrence, Kansas 66049
U.S. Geological Survey

Books and Open-File Reports

Denver Federal Center

Box 25425

Denver, Colorado 80225 


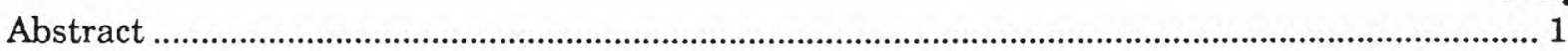

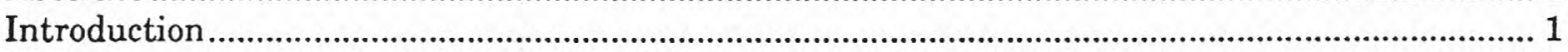

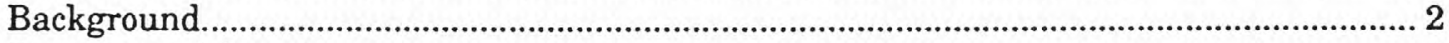

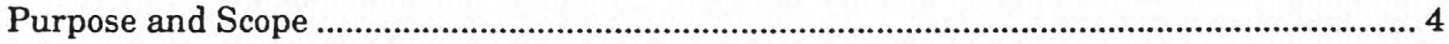

Acknowledgments ........................................................................................................... 4

Description of nonpoint-source contamination problem and related studies .................................... 4

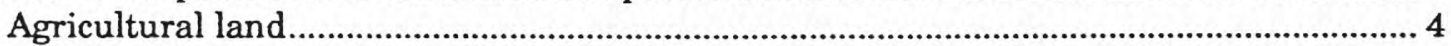

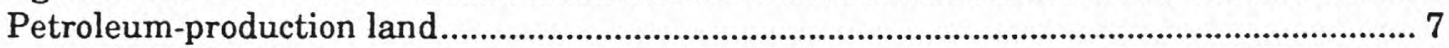

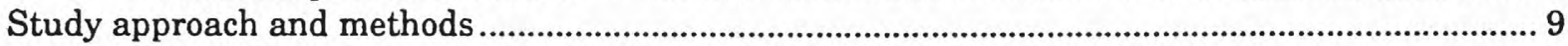

Characterization of contaminant sources ...................................................................... 9

Agricultural land ...................................................................................... 10

Petroleum-production land ...................................................................................... 10

Factors relevant to the development and assessment of contamination ............................ 10

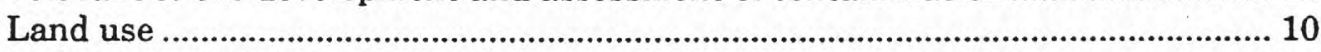

Unsaturated-zone lithology ............................................................................ 12

Type of well sampled......................................................................................... 13

Sampling design and procedures ..................................................................................... 13

Sampling design ...................................................................................................... 13

Sampling procedures.............................................................................................. 16

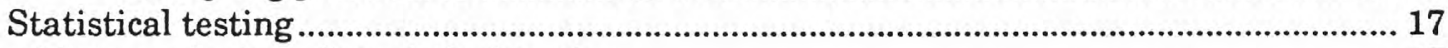

Results of data analysis and statistical testing............................................................................ 17

Inorganic constituents ..................................................................................................... 17

Comparisons by land use .................................................................................. 17

Comparisons by unsaturated-zone lithology ............................................................ 18

Comparisons by type of well sampled .................................................................... 22

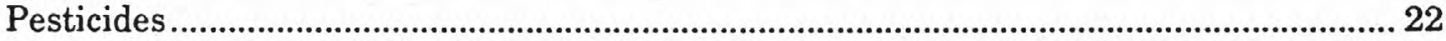

Comparisons by land use .................................................................................... 26

Comparisons by unsaturated-zone lithology ........................................................... 28

Comparisons by type of well sampled ..................................................................... 28

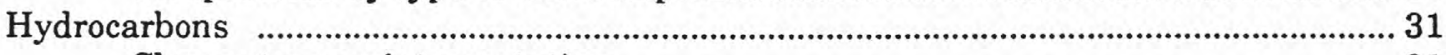

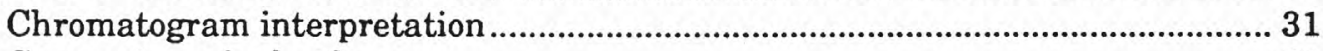

Comparisons by land use ....................................................................................... 31

Comparisons by unsaturated-zone lithology ........................................................ 35

Discussion of results

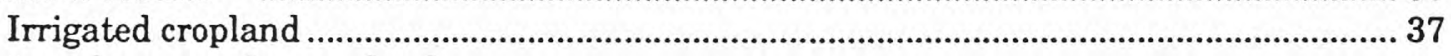

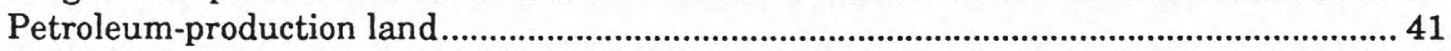

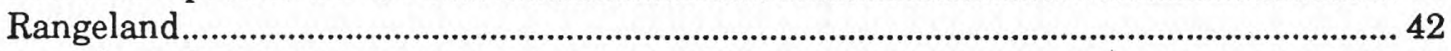

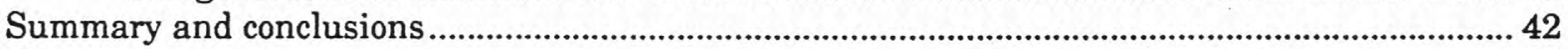

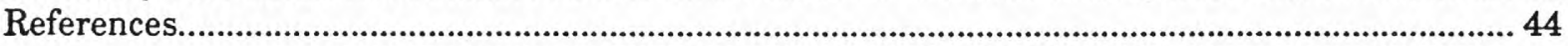

\section{ILLUSTRATIONS}

Figures 1-2. Maps showing:

1. High Plains aquifer and location of study area …........................................................ 3

2. Generalized predominant land use in Kansas......................................................... 5

3. Diagram showing pathways of pesticide degradation and transport............................ 6

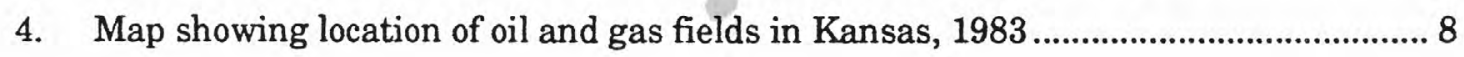




\section{ILLUSTRATIONS--Continued}

Figure 5. Schematic section showing movement of brine from a brine-disposal pond

Figures 6-7. Map showing:

6. Discrete land-use areas delineated as basis for ground-water sampling.

7. Regionalized unsaturated-zone lithology

8. Diagram showing groupings of water samples for statistical comparisons and number of sampled wells in each group

Figures 9-17. Graphs showing:

9. Concentrations of dissolved solids and selected major ions in water samples from small-yield wells grouped according to land-use area

10. Confidence levels of differences between median property values or inorganicconstituent concentrations in water samples from small-yield wells in different land-use areas, based two-tailed Wilcoxon-Mann-Whitney rank-sum tests

11. Concentrations of dissolved solids and selected major ions in water samples from small-yield wells in areas of irrigated cropland, grouped according to unsaturated-zone lithology

12. Confidence levels of differences between median property values or inorganicconstituent concentrations in water samples from small-yield wells in areas of clayey and sandy unsaturated-zone lithology, grouped according to land-use areas and based on two-tailed Wilcoxon-Mann-Whitney rank-sum tests.

13. Confidence levels of differences between median property values or inorganicconstituent concentrations in water samples from irrigation wells in areas of clayey and sandy unsaturated-zone lithology, based on two-tailed WilcoxonMann-Whitney rank-sum tests.

14. Confidence levels of differences between median property values or inorganicconstituent concentrations in water samples from small-yield wells in different land-use areas, grouped according to unsaturated-zone lithology and based on two-tailed Wilcoxon-Mann-Whitney rank-sum tests

15. Confidence levels of differences between median property values or inorganicconstituent concentrations in water samples from small-yield wells in areas of irrigated cropland and petroleum-production land, grouped according to unsaturated-zone lithology and based on two-tailed Wilcoxon-Mann-Whitney rank-sum tests.

16. Concentrations of dissolved solids and selected major ions in water samples from wells in areas of irrigated cropland, grouped according to types of well sampled. 


\section{ILLUSTRATIONS--Continued}

Page

Figure 17. Confidence levels of differences between median property values or inorganicconstituent concentrations in water samples from small-yield wells and irrigation wells in areas of irrigated cropland, based on two-tailed WilcoxonMann-Whitney rank-sum tests.

18. Map showing location of detections and nondetections of atrazine in groundwater samples.

19. Example of chromatogram produced from analysis of ground-water sample by gas chromatography with flame-ionization detection

20. Chromatograms for a collected sample and a laboratory blank that were compared to identify peaks representing organic compounds present in ground water

21. Chromatogram for a collected sample and method of measuring peak height to represent relative concentration of organic compound

Figures 22-23.--Graphs showing:

22. Estimated total concentrations of organic compounds in ground-water samples from areas of petroleum-production land and rangeland

23. Frequencies of occurrence of individual organic compounds in areas of petroleum-production land and rangeland, based on gas-chromatograph retention time

\section{TABLES}

Table 1. Summary of selected water-quality data grouped according to land-use areas 18

2. Frequency of detections of pesticides in ground-water samples grouped according to land-use areas, unsaturated-zone lithology, and type of well sampled

3. Summary of statistical comparisons of median property values and inorganicconstituent concentrations in ground-water samples, group according to landuse areas, unsaturated-zone lithology, and type of well sampled

4. Summary of statistical comparisons of atrazine detections in ground-water samples, grouped according to land-use areas, unsaturated-zone lithology, and type of well sampled.

5. Summary of statistical comparisons of hydrocarbon-compound detections and relative concentrations in ground-water samples, grouped according to ianduse areas and unsaturated-zone lithology

6. Results of water-quality analyses, grouped according to land-use areas, unsaturated-zone lithology, and type of well sampled. 


\section{CONVERSION FACTORS AND VERTICAL DATUM}

Multiply

foot (ft)

mile (mi)

acre

square mile $\left(\mathrm{mi}^{2}\right)$

foot per day (ft/d)

gallon per minute (gal/min)

pound (lb)

barrel (bbl)

degree Fahrenheit $\left({ }^{\circ} \mathrm{F}\right)$

$1{ }^{\circ} \mathrm{C}=\left({ }^{\circ} \mathrm{F}-32\right) / 1.8$.
By

To obtain

0.3048

1.609

0.4047

2.590

0.3048

0.06309

0.4536

0.1590

(1) meter

kilometer

square hectometer

square kilometer

meter per day

liter per second

kilogram

cubic meter

degree Celsius $\left({ }^{\circ} \mathrm{C}\right)$

Sea level: In this report, "sea level" refers to the National Geodetic Vertical Datum of 1929--a geodetic datum derived from a general adjustment of the first-order level nets of the United States and Canada, formerly called Sea Level Datum of 1929. 
by

\author{
John O. Helgesen, Lloyd E. Stullken, and A.T. Rutledge
}

\title{
ABSTRACT
}

Ground-water quality was assessed in a 5,000-square-mile area of the High Plains aquifer in south-central Kansas that is susceptible to nonpoint-source contamination from agricultural and petroleum-production activities. Of particular interest were agricultural chemicals, mainly atrazine, and oil-derived hydrocarbons, which might occur in association with brines that formerly were disposed into unlined ponds.

Random sampling of ground water was done within a framework of discrete land-use areas (irrigated cropland, petroleum-production land containing former brine-disposal ponds, and undeveloped rangeland) of 3 to 10 square miles. Although true baseline water-quality conditions probably are rare, these baseline conditions are represented most closely by ground water beneath the areas of undeveloped rangeland. The sampling design enabled statistical hypothesis testing of the effects of land use, unsaturated-zone lithology, and type of well sampled. Statistical testing was based on nonparametric procedures.

Results indicate that regional ground-water quality has been affected by prevailing land-use activities, as shown mainly by increased concentrations of several inorganic constituents. Ground water beneath irrigated cropland is characterized by significantly (95-percent confidence level) larger concentrations of hardness, alkalinity, calcium, magnesium, potassium, fluoride, and nitrite plus nitrate than is water beneath undeveloped rangeland. Nondegraded pesticides generally were not detected in the aquifer, probably because of degradation and sorption. Atrazine is present locally in ground water in small concentrations.

Ground water beneath petroleum-production land is characterized by significantly (95-percent confidence level) larger concentrations of hardness, alkalinity, dissolved solids, sodium, and chloride than is water beneath undeveloped rangeland. Nonpoint-source ground-water contamination by oil-derived hydrocarbons was not discernible. The occurrences of trace-organic compounds were similar between petroleum-production land and undeveloped rangeland, which indicates a natural origin for these compounds.

The unsaturated zone in the study area is lithologically heterogeneous and contains substantial amounts of clay that inhibit the downward movement of water and solutes. Within the aquifer, the rate of regional lateral flow and solute transport is sufficiently slow so that the ground-water quality reflects overlying land use in discrete areas of several square miles. Regional flow, however, is sufficiently rapid so that the type of well sampled is not important in regional characterization of water quality beneath irrigated cropland; the seasonal pumping of irrigation wells does not appear to divert regional flow enough to cause substantial local anomalies of more mineralized ground water.

\section{INTRODUCTION}

Increased public concern has directed attention toward the varied and complex aspects of ground-water contamination. Assessing and understanding the effects of human activities on ground-water quality to address effectively the scope of and response to contamination problems has become a matter of national importance.

Study of nonpoint-source contamination is a part of the U.S. Geological Survey's Toxic Waste--Ground-Water Contamination Program. The general objective of the program is to assess the 
current quality of the Nation's ground-water reserves and the nature and extent of the ground-water contamination problem (Helsel and Ragone, 1984). As part of this effort, seven areas for the study of nonpoint-source contamination were selected to include representative environments in terms of climate, geohydrology, and human activity. The studies were designed to be regional in scope and statistical in approach, and to allow for subsequent work directed toward the extrapolation of results or the focusing on particular aspects important to understanding nonpoint-source ground-water contamination. Three of the seven study areas are in the midwestern United States, and one of these study areas, part of the High Plains aquifer in Kansas, is the subject of this report.

\section{Background}

Ground water is a vital resource to the midwestern United States. The most common sources of water supply are shallow, unconfined, unconsolidated aquifers that might be extremely transmissive and have a large storage capacity. The High Plains aquifer is the most areally extensive of these aquifers, but smaller alluvial or glacial-outwash aquifers are present throughout much of the Midwest. These aquifers are readily available sources of water that is needed for public-supply, agricultural, industrial, domestic, and stock purposes. Although contamination of any water resource might have substantial health-related and economic consequences, ground-water contamination can be a particularly serious problem because movement of ground water is slow and does not favor dispersal of contaminants; cleanup of contaminated ground water usually is difficult or impossible.

Surficial aquifers with substantial permeability and a shallow water table are especially susceptible to contamination by human activities located at or near the land surface. Possible sources of contamination range from local (point-source) to widespread (nonpoint-source) activities. This study addresses nonpoint-source organic contaminants associated with two activities practiced extensively across much of the Midwest. These activities, agricultural-chemical application and brine disposal associated with petroleum production, pose potential ground-water contamination problems as a result of their widespread practice. Application of agricultural chemicals involves a spreading of the chemicals over the land. These chemicals then have the potential to move down to the water table. Brines produced with oil and oil-derived hydrocarbons, which can occur in association with brines, also might be a problem, particularly as a result of brine-disposal practices prior to regulation. This study also addresses relations among contaminant concentration or detection and two variables--unsaturated-zone lithology and the type of well sampled.

Delineation of contaminant distributions, in conjunction with improved understanding of the major factors affecting these distributions, will help in assessing the current problem and contribute toward effective monitoring, predictive capability, and ultimate protection of water resources. The contamination problem is complex. The direction and velocity of regional ground-water flow potentially are major factors affecting the regional distribution of contaminants in an aquifer. Superimposed on the regional hydrology are local factors, such as natural hydrogeologic variations or local flow-pattern distortions caused by pumping. Many other processes that affect contaminant distribution, such as rate and timing of recharge, degradation, and sorption, also need to be considered in evaluating the contamination problem.

The area selected for this study (fig. 1) is a small part of the High Plains aquifer, yet sufficiently large to address the regional scale of the problem. The $5,000-\mathrm{mi}^{2}$ area is within the Great Bend Prairie and Equus beds areas of south-central Kansas. The study area is a logical unit for investigation of nonpoint-source contaminant distribution in ground water because the area is characterized by permeable soils and a shallow water table (typically less than $30 \mathrm{ft}$ below the land surface). The potential for contamination of ground water in the area apparently is reflected in large nitrate concentrations in ground water relative to other areas of Kansas (Spruill, 1983).

Aquifer hydrology of this area is well defined (Williams and Lohman, 1949; Stramel, 1956, 1967; Fader and Stullken, 1978; Hathaway and others, 1978, 1981; Cobb and others, 1983; Sophocleous, 1983; Spinazola and others, 1985; Stullken and others, 1985). The aquifer consists of a 


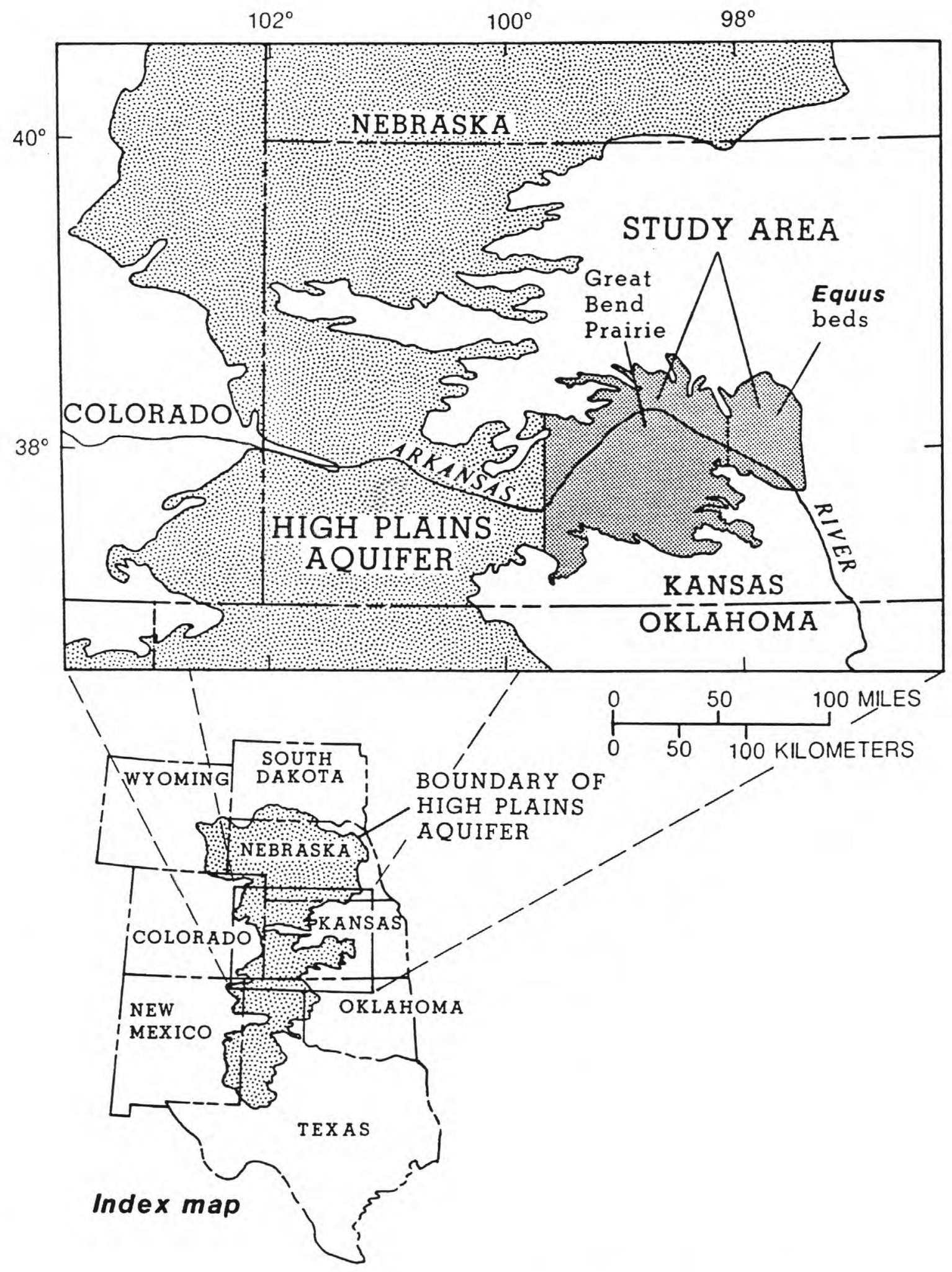

Figure 1. High Plains aquifer and location of study area. 
heterogeneous sequence of clay, silt, sand, and gravel that is principally of alluvial origin. The aquifer contains and transmits water derived mainly from local precipitation that percolates downward to the water table. Unconfined conditions predominate, and regional ground-water flow generally is from west to east.

\section{Purpose and Scope}

This report characterizes the occurrences of nonpoint-source contaminants in the High Plains aquifer in south-central Kansas and evaluates these occurrences in relation to land use, unsaturated-zone lithology, and type of well sampled. Although his report addresses overall ground-water quality, it focuses particularly on the occurrence of organic contaminants (pesticides and oil-derived hydrocarbons) associated with agriculture and petroleum production. Certain pesticides, such as atrazine and 2,4-D, are of particular concern because of extensive use and relative persistence or mobility. Specific hydrocarbons are not targeted, however, because potential petroleum-related contaminants include a variety of compounds.

\section{Acknowledgments}

The cooperation of many individuals and agencies was essential for the completion of this study. The authors appreciate the permission granted by well owners for collection of water samples. Also acknowledged are: the Kansas Department of Health and Environment (Topeka) for providing water-well records; the Kansas Geological Survey (Lawrence) for sharing gamma-log and water-well data; the Kansas Corporation Commission (Topeka) for information concerning brine-disposal ponds; and Kansas Groundwater Management Districts Nos. 2 (Halstead) and 5 (Stafford) for sharing their information and experience pertaining to the study area.

\section{DESCRIPTION OF NONPOINT-SOURCE CONTAMINATION PROBLEM AND RELATED STUDIES}

\section{Agricultural Land}

Land use in Kansas (fig. 2) is typical of much of the Midwest and is largely agricultural. Pesticides (synthetic organic chemicals used principally for weed and insect control) are applied extensively to enhance crop productivity. The distribution of an agricultural chemical in ground water is a result of numerous factors, including source, movement, and fate of the chemical. Applications of pesticides are widespread and many different pesticides are applied, but in most instances application histories are not documented. In addition, timing of applications with respect to natural recharge and irrigation are important factors that affect pesticide infiltration. Other factors include properties of soils and the underlying unsaturated zone, properties of the chemical that relate to contamination potential (such as solubility, degradability, and sorption characteristics), and lithologic and hydraulic properties that affect the distribution of the compound in the saturated zone.

The multiple pathways available to a pesticide (Cheng and Koskinen, 1986; Severn, 1987) make its tracking through the natural environment difficult. This complexity is illustrated schematically in figure 3. After application, the pesticide can be discharged with surface runoff, lost to volatilization, or infiltrated into the soil. Within the root zone, part of the pesticide can undergo chemical or biological degradation, part goes to plant uptake, and part might continue percolating through the unsaturated zone. A substantial proportion also may be sorbed onto organic or clay materials. If the pesticide reaches the saturated zone, degradation normally is slowed considerably (Severn, 1987), and subsequent distribution probably is determined largely by flow patterns prevailing within the aquifer. The great number of possible combinations of pesticides, their characteristics, and hydrologic conditions result in serious shortcomings in the ability to predict the effects of pesticides on ground-water quality. 


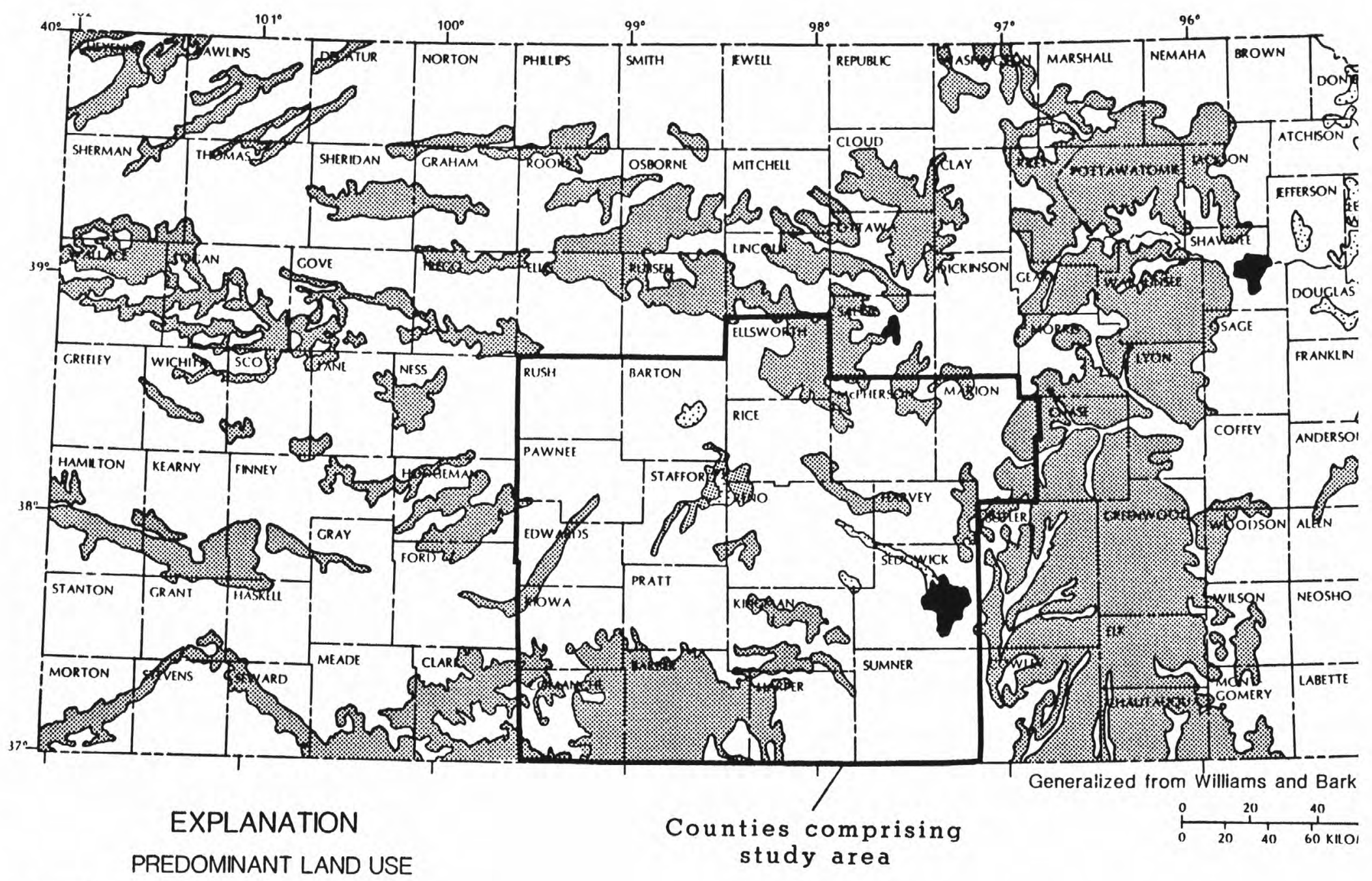

$\square$ Cropland Woodland, water,

Rangeland

Urban land

Figure 2. Generalized predominant land use in Kansas. 


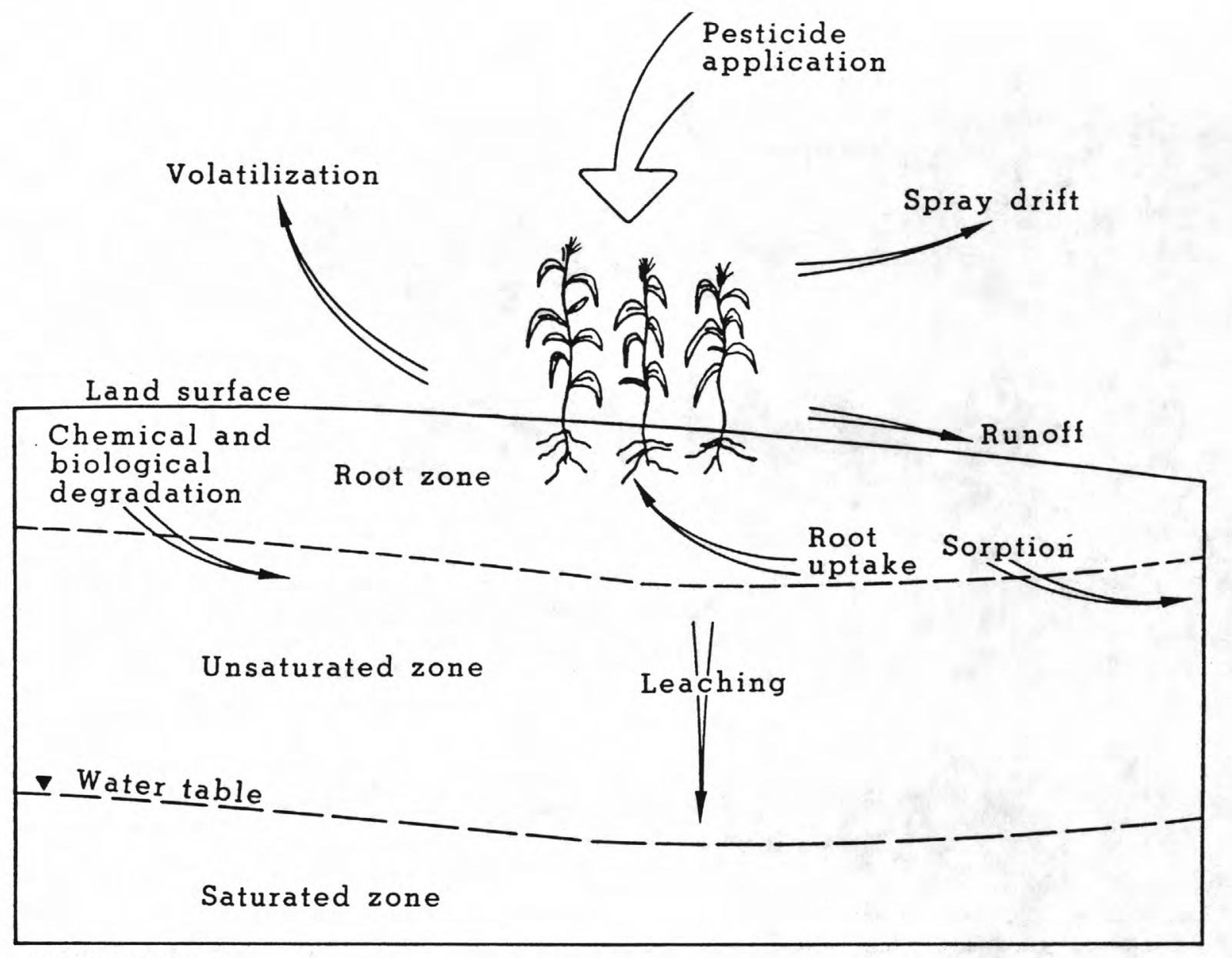

NOT TO SCALE

Modified from Severn (1987)

Figure 3. Pathways of pesticide degradation and transport.

Awareness of ground-water contamination by pesticides in the Midwest has increased considerably during the last few years, and several Midwestern States have conducted surveys to begin defining and monitoring the problem. Most of the data from these surveys are available but unpublished. Pesticides targeted for study vary from State to State depending on the pesticides in common use. Some of the pesticides typically of concern include alachlor, aldicarb, atrazine, carbofuran, cyanazine, metolachlor, metribuzin, and 2,4-D. The pesticide surveys generally have not systematically evaluated the nonpoint-source contamination problem, but have provided initial indications of pesticide occurrences in ground-water supplies. Some of the largest concentrations detected probably represent localized point-source problems.

The Kansas Department of Health and Environment (Topeka) retrieved U.S. Environmental Protection Agency data in 1984 showing that 58 out of 1,736 samples (3 percent) collected from water wells across Kansas between 1972 and 1984 had detectable pesticide concentrations. The most common pesticides detected were 2,4-D, aldrin, dieldrin, and dacthal. A 1985-86 random sampling of 103 farmstead wells in 48 counties in Kansas determined that 9 percent had detectable pesticides (Koelliker and others, 1987). Atrazine was the most frequently detected pesticide, with concentrations as large as $7.4 \mu \mathrm{g} / \mathrm{L}$ (micrograms per liter). Other pesticides, detected only once, were alachlor, chlordane, heptachlor epoxide, picloram, 2,4-D, and 2,4,5-T. Picloram was detected at a concentration of $5.6 \mu \mathrm{g} / \mathrm{L}$, and concentrations of other compounds were less than $1.3 \mu \mathrm{g} / \mathrm{L}$. Perry and others (1988) summarized agricultural-chemical use, factors affecting leaching, and ground-water quality assessments in Kansas. Those authors reported that 56 wells in areas of permeable soils and shallow 
water table were sampled and analyzed for triazine herbicides during 1985-86 and that these herbicides were detected in 20 percent of the samples, with atrazine the most frequently detected.

The common practice of irrigation introduces water, supplemental to precipitation, for the leaching of pesticides and thus might be an important factor affecting pesticide migration. Luckey and others (1986) estimated that return flows to the water table from irrigation on the High Plains are substantial and might be as much as 30 to 50 percent of pumpage withdrawal.

Concern has developed regarding the practice of chemigation (application of agricultural chemicals by injection into irrigation water and distribution through the irrigation system) in intensively irrigated areas such as in many parts of Kansas (Genna Ott, Kansas Department of Health and Environment, written commun., 1984). Direct potential for contamination exists through back-siphoning of chemicals into the supply well if it is not properly equipped with a backflow-prevention device. Also, chemicals could contaminate the aquifer as a result of defective well construction. Analyses of water from 138 chemigation wells in 1988 showed detectable pesticides in 4 percent of the samples; the chemigation process itself does not appear to result in greater incidence of contamination (Perry and Anderson, 1991).

Pesticide compounds vary considerably in their persistence characteristics in the subsurface environment. Half-lives in soil are on the order of weeks or months for many pesticides, but might be much longer in the saturated zone. Study of a point-source contamination problem near Hesston, Kansas (Perry, 1990), permitted determinations of half-lives in the saturated zone on the order of years for atrazine and other herbicides. The potential for long-term persistence also is demonstrated by results of stream-water analyses; for example, H. E. Bevans (U.S. Geological Survey, written commun., 1989) reports atrazine in base flow of northeastern Kansas streams, reflecting transport through the ground-water system that probably took years.

An initial reconnaissance sampling of part of the study area described in this report was done in August and September 1984 (Stullken and others, 1987). Thirteen samples were collected from wells in areas of irrigated cropland, and 14 samples were collected from areas of rangeland. Analyses were performed for several classes of pesticides--triazine and other nitrogen-containing herbicides, chlorophenoxy-acid herbicides, and carbamate, organochlorine, and organophosphate insecticides. The only pesticides detected were 2,4-D, atrazine, and propazine. The herbicide 2,4-D was reported in 23 of the 27 samples. Atrazine was detected in two samples, and propazine was detected in one sample. All concentrations were small, with the largest being $0.20 \mu \mathrm{g} / \mathrm{L}$ for atrazine.

\section{Petroleum-Production Land}

Hydrocarbons, a large group of organic compounds consisting of hydrogen and carbon, typically are associated with petroleum and petroleum-related activities. This group includes a variety of compounds with widely varying properties. Virtually no documentation of nonpoint-source hydrocarbon contamination of ground water exists. Recognition of the potential for hydrocarbon contamination on a regional scale is based mainly on conceptual inference in combination with a few instances of reported hydrocarbon occurrence.

The extent of petroleum-production activity in Kansas (fig. 4) is indicative of the potential regional effect of this activity on water quality of the High Plains aquifer. Surface areas affected by petroleum production range from about 0.1 acre of land containing a single well to large tracts devoted exclusively to petroleum-related operations, such as refining and storage. Brine produced in conjunction with oil is the major potential ground-water contaminant in Kansas in terms of volume generated (Power, 1982). According to the Kansas Department of Health and Environment (1982), an average of $23 \mathrm{bbl}$ of brine accompanies each barrel of oil produced. Most of the brine currently produced is reinjected into the producing zone or other saltwater-bearing formations. Prior to the 1960's, it was not an uncommon practice to dispose of oil-field wastes (mostly brine) into shallow, unlined pits. The attendant potential contamination problem has been long recognized (Frye and Brazil, 1943). 


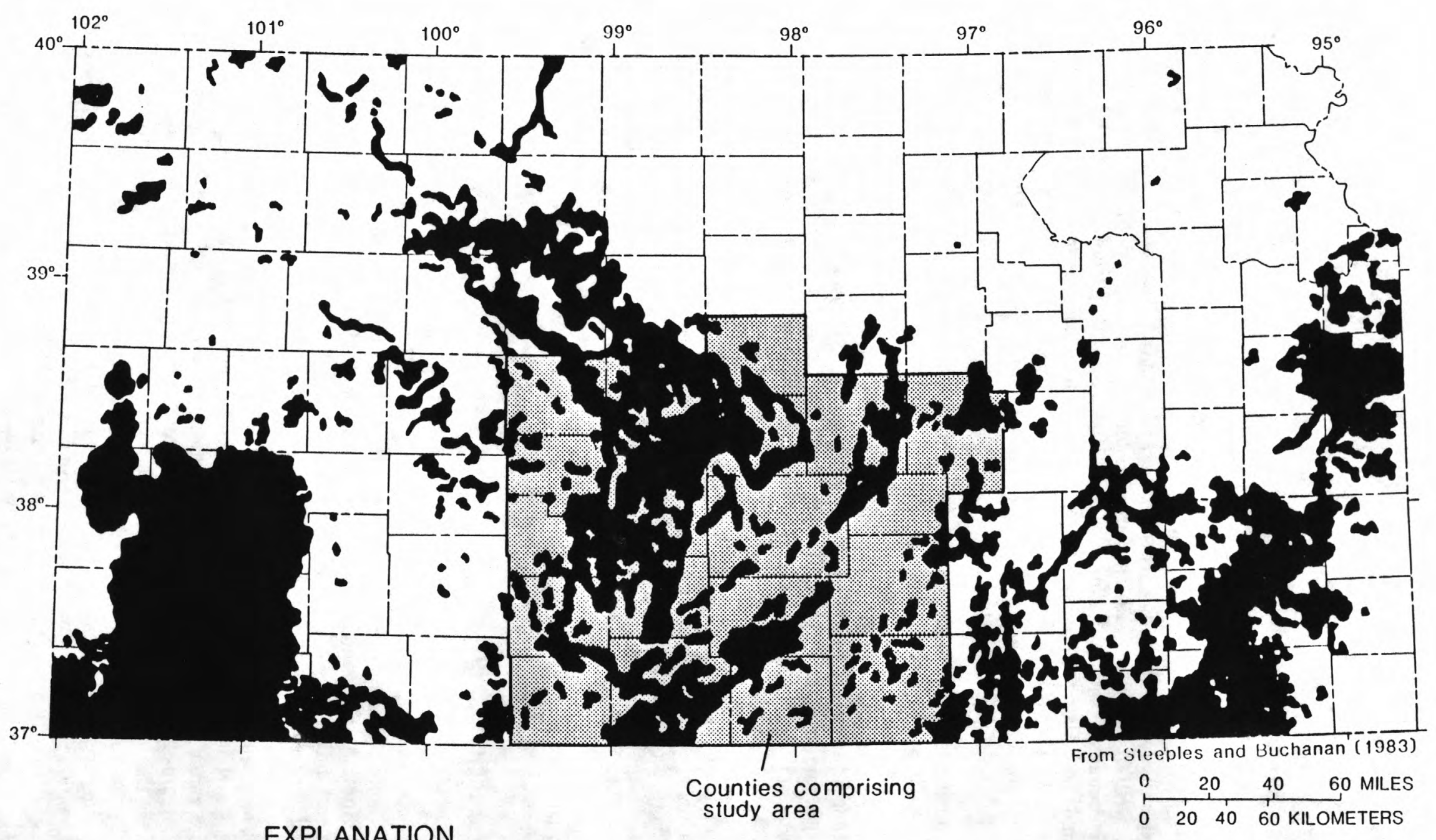

EXPLANATION

- OIL OR GAS fIELD

Figure 4. Location of oil and gas fields in Kansas, 1983. 
Infiltration of the wastes through the soil and into the freshwater of the underlying aquifer (illustrated schematically in fig. 5) has been documented. Leonard and Berry (1961), for example, described such a contamination problem northwest of the study area in Ellis County. In western Harvey and eastern Reno Counties (within the study area), brine contamination of ground water originated from former disposal pits, a leaky pipeline collection system, and possibly in response to increased hydraulic pressure from below the aquifer caused by brine injection (Burrton Task Force, 1984).

Because brine is produced with petroleum and is in direct contact with petroleum during production, some hydrocarbons also are associated with the brine during disposal. Thus, where ground water has been affected by improper disposal of oil-field brine, hydrocarbons from the associated petroleum also might constitute contaminants.

Volatile organic compounds occasionally have been detected in ground-water samples collected in Kansas. In the previously mentioned 1985-86 sampling of 103 farmstead wells, 2 percent had detectable volatile organic compounds (Koelliker and others, 1987). Many sources for such compounds are possible, but one possibility can be related to oil-production activities. The existence and extent of any such problem currently (1990) is unknown.

\section{STUDY APPROACH AND METHODS}

Study of nonpoint-source contamination entails: (1) characterization of the contaminant sources; (2) consideration of factors relevant to the development and assessment of contamination; (3) formulation of an appropriate sampling design and sampling procedures for collection of pertinent and representative data; and (4) application of statistical methods to evaluate the importance of relevant factors. Each of these aspects is discussed in the following sections.

\section{Characterization of Contaminant Sources}

The two types of organic contaminants of concern in this study have different origins that can be characterized basically in terms of land use. Attention to land use is primary to the study for

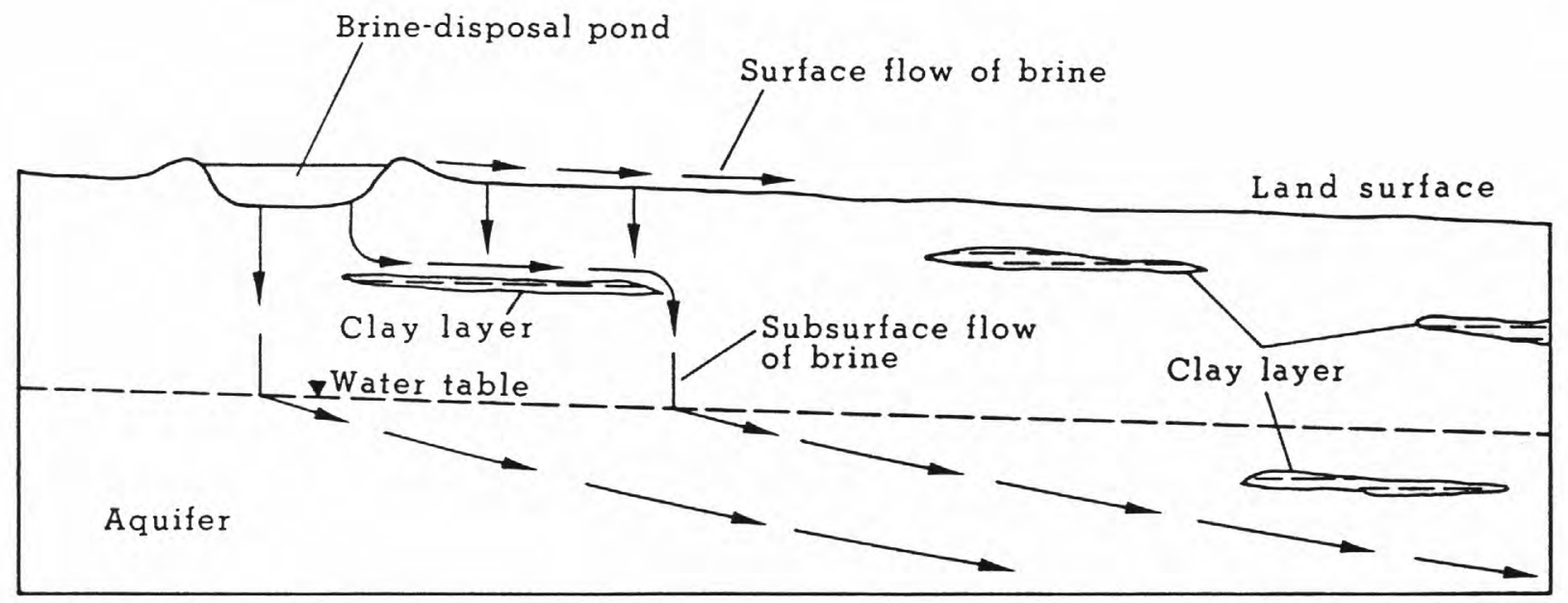

NOT TO SCALE

Modified from Leonard and Berry (1961)

Figure 5. Movement of brine from a brine-disposal pond. 
consistency with the overall program emphasis of defining felations between ground-water quality and prevailing human activities (Helsel and Ragone, 1984). Quantification of contaminant sources probably would be done best on the basis of chemical-application volumes (of pesticides on agricultural land) and disposal volumes (of oil-derived hydrocarbons on petroleum-production land). However, such data are limited, precluding a quantitative system appraisal of contamination in the study area.

\section{Agricultural Land}

The regional occurrence of pesticides in ground water was defined in reference to agricultural land use in the study area. Nearly the entire area is cropland or rangeland; the largest nonagricultural areas are a wildlife refuge and principal communities. Attention was directed to areas of irrigated cropland and rangeland. Although both types of land receive pesticide applications, irrigated cropland receives much more and also receives applications of water, which increase the potential for downward leaching of chemicals.

Some general information about pesticide applications was available. Nilson and Johnson (1980) assembled 1978 pesticide-use data for multicounty areas within Kansas; Perry and others (1988) also summarized these data. During 1978, 28.1 million pounds of active pesticide ingredients were applied statewide. Herbicides accounted for 85 percent of the total, and atrazine was the most intensively used (21 percent of the total). In terms of acreage, 2,4-D was the most extensively applied.

Atrazine and 2,4-D were the two most intensively used pesticides in south-central Kansas (Perry and others, 1988), an area that approximately coincides with the study area. During 1978 in south-central Kansas, application of atrazine exceeded 370,000 lb (mostly on sorghum or corn), and application of 2,4-D exceeded $400,000 \mathrm{lb}$ (mostly on pasture and rangeland). These herbicides have seen detected in ground-water samples from the area (Stullken and others, 1987; Bevans, 1989) and are the principal pesticides of concern in this study.

\section{Petroleum-Production Land}

The regional occurrence of hydrocarbons in ground water was defined in reference to petroleum-production land use in the study area. Oil-derived hydrocarbons might have accompanied brines as they percolated downward from former brine-disposal ponds, as discussed in "Description of Nonpoint-Source Problem and Related Studies." Most oil-production activity is located within designated oil fields ranging in size from a fraction of a square mile to several square miles or larger. Virtually all disposal ponds also are situated within the boundaries of the oil fields; therefore, these oil fields form a logical frame of reference for studying water quality that might be related to this activity.

Amounts of organic contaminants that might be associated with the oil-production brines are unknown. Reported rates of brine disposal at pond locations are available and could indicate relative potential for hydrocarbon contamination. Concentrations of oil-derived hydrocarbons in the brines, however, could vary considerably depending on the brine-oil ratio and effectiveness of the separation process.

\section{Factors Relevant to the Development and Assessment of Contamination}

Many factors might affect the development of and, thus, the assessment of, nonpoint-source contamination. Factors considered particularly important in this study were land use, unsaturated-zone lithology, and type of well sampled.

\section{Land Use}

Regional ground-water quality was characterized in relation to associated predominant land-use areas. Contiguous areas of 3 to $10 \mathrm{mi}^{2}$ were identified for irrigated cropland, petroleum-production land, and virtually undeveloped rangeland (fig. 6). Such a size was considered 


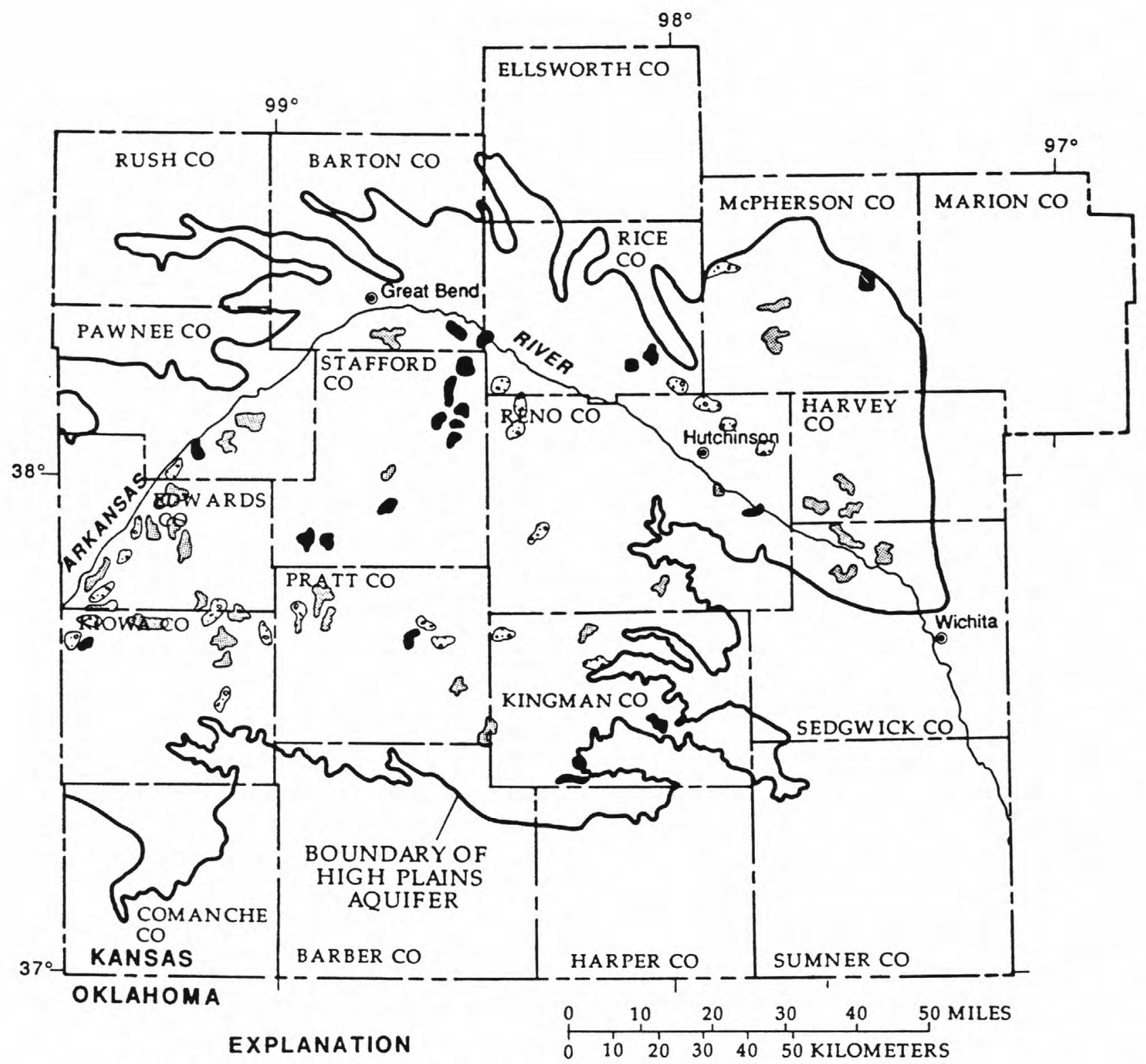

DISCRETE LAND-USE AREAS WITHIN

BOUNDARY OF HIGH PLAINS AQUIFER

2. Irrigated cropland

Petroleum-production land

Rangeland

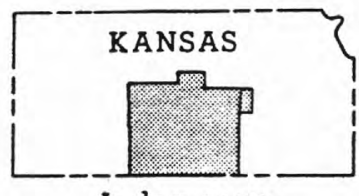

Index map

Figure 6. Discrete land-use areas delineated as basis for ground-water sampling. 
appropriate for establishing relations between contaminant occurrence and prevailing land use, in view of the slow movement of ground water. Regional lateral-flow velocity generally is less than $1 \mathrm{ft} / \mathrm{d}$ (Stullken and others, 1987). Consequently, during the last few decades, when most contamination has occurred, ground water would not have moved much beyond the discrete areas of several square miles; therefore, ground-water quality can be related to general areas of overlying land use. Delineation of areas in narrow, elongate shapes was avoided to decrease the possibility that sampled ground-water quality does not reflect the overlying land use because of displacement by regional flow.

The discrete land-use areas were outlined so as not to overlap and to be as mutually exclusive as possible because spatial independence is important for distinguishing overall ground-water quality. Accordingly, areas of irrigated cropland were chosen that do not overlap with oil fields; areas of petroleum-production land were delineated to contain as little irrigated cropland as possible (that is, rangeland predominates except for the sites containing oil wells and associated structures); and areas of undeveloped rangeland were outlined to exclude irrigated cropland and oil fields.

Although pesticides are applied to some rangeland, 1978 data from Nilson and Johnson (1980) showed that only about 7 percent of pasture and rangeland received applications. Fertilizer use on rangeland also is limited (P.D. Ohlenbusch, Kansas State University, written commun., 1990). Therefore, the rangeland is mostly undeveloped and serves as a useful "control" category. "Baseline" conditions might be most closely represented by the areas of rangeland.

Landsat-satellite imagery for late July and early August of 1984 was selected as the primary basis for delineating agricultural land-use areas. Imagery for this period had virtually no cloud-cover interference and provided sufficiently recent land-use information. Coverage was obtained from black-and-white band-2 images containing tonal contrasts useful for identifying irrigated crops at mid-summer development stages. Rangeland was mapped on the basis of textural and tonal qualities of the imagery, with reference to older (1974) land-use maps prepared by the U.S. Geological Survey (1979a, 1979b, 1979c, 1979d). Minor changes in rangeland distribution in the study area between 1974 and 1984 permitted the older information to be used as an effective guide. Use of the older maps for identifying areas of irrigated cropland was not possible, however, because irrigated nd nonirrigated cropland are not differentiated on those maps.

For purposes of this study, areas of petroleum production were defined as areas of collective occurrences of inactive brine ponds. For practical purposes, "inactive" ponds might be considered as those generally of pre-1957 construction from which leakage could be a residual problem and, thus, of concern in this study. "Active" ponds mostly are those installed after regulations requiring proper construction were imposed (1957) and are unlikely to be sources of contamination; active ponds are much fewer, and most are used for temporary storage of brine before subsurface disposal through deep wells. Information was obtained from the Kansas Corporation Commission describing the location of inactive brine-disposal ponds. This information was helpful for this study because pond-disposal methods were not used uniformly across oil-field areas; some production companies injected brine through deep wells. The compilation of brine-pond locations is incomplete, but sections of land containing inactive ponds were noted, and coverage was sufficient to define numerous areas of pond aggregations. Several sections of rangeland containing inactive brine ponds and forming a contiguous 3 - to $10-\mathrm{mi}^{2}$ area defined an area of petroleum-production land.

\section{Unsaturated-Zone Lithology}

Another factor affecting the occurrence and distribution of contaminants in the ground-water system is the presence of fine-grained materials in the unsaturated zone, which can inhibit downward movement of water and chemicals. Differences in ground-water quality associated with lithologic variations in the unsaturated zone could demonstrate the significance of this factor on downward movement of contaminants to the aquifer.

Clay deposits reportedly are common at shallow depths within the study area, according to 
Stullken and Fader (1976), Sophocleous and Perry (1987), and other workers familiar with the area; however, the lithology has not been mapped. Lithologic mapping for this study was based on existing information for the top $20 \mathrm{ft}$ of the unsaturated zone below the soil (this interval comprises most of the unsaturated zone throughout the study area). The interpretation is based on about 80 gamma-ray logs and about 350 descriptive logs available for much of the area. Although reported lithologies were obtained from several different sources, generalized regional patterns of comparative clay thickness were mapped (fig. 7). Because of the scarcity of definitive log data in parts of the area and considerable local lithologic variability, the interpretation is shown as only two categories--"clayey" areas defined arbitrarily as containing at least 25 percent clay in the unsaturated zone, and "sandy" areas containing less than 25 percent clay. All delineated land-use areas then were identified as occurring in either a "clayey" or "sandy" area for the purpose of evaluating results in terms of unsaturated-zone lithology.

\section{Type of Well Sampled}

A further consideration in evaluating ground-water contamination is the source of samples on which the description of water quality is based. Results might be dependent on the location and yield of the sampled well to the extent that: (1) the introduction of contaminants to the ground-water system is nonuniform within the specified land-use area of concern, and (2) the distribution of contaminants within the aquifer is modified by the natural or stressed hydraulic conditions of the system. Nonuniform introduction of contaminants to the system can result from nonuniform source distribution or spatial variations of factors that affect the movement or persistence of constituents in the subsurface. Variations in constituent concentrations with depth have been reported within the study area (Huntzinger and Stullken, 1988) and in the High Plains aquifer in Nebraska (Chen and Druliner, 1987; Druliner, 1989). Local conditions might have a substantial effect on ground-water quality at any given location. Site-specific definition of these complexities, however, is not practical for this regional assessment, and a statistical sampling approach is used, as discussed in the "Sampling Design and Procedures" section.

The type of well sampled could be particularly important in areas of irrigated cropland where irrigation water is withdrawn from large-yield wells (generally greater than $500 \mathrm{gal} / \mathrm{min}$ ). Samples from irrigation wells, which typically are located within the irrigated fields, potentially contain larger concentrations of an agricultural contaminant than do samples from small-yield wells (normally those that are drilled for domestic or stock use and yield less than $30 \mathrm{gal} / \mathrm{min}$ ) located away from the fields. irrigation wells develop cones of depression directly beneath the areas of chemical application and potentially cause local recirculation of water and contaminants. In the initial reconnaissance of Stullken and others (1987), the only irrigation well sampled yielded water containing the largest pesticide concentration. Well yield generally is not relevant to characterization of ground-water quality beneath rangeland because of a lack of large-yield wells. Nonpoint-source contaminants beneath rangeland, whether agriculture- or petroleum-related, are less likely to be diverted from natural regional ground-water flow patterns.

\section{Sampling Design and Procedures}

Characterization and evaluation of nonpoint-source contamination in the study area primarily is based on regional sampling of ground water to allow the evaluation of the significance of the selected factors previously discussed. Details of the sampling are described in the following sections.

\section{Sampling Design}

The basic framework for sampling consists of the discrete land-use areas shown in figure 6 . These areas consist of 30 areas of irrigated cropland, 22 areas of petroleum-production land, and 22 areas of undeveloped rangeland.

The sampling plan was developed to enable several modes of statistical comparison in terms of ground-water quality (fig. 8). The primary comparison was among the three categories of land use. 


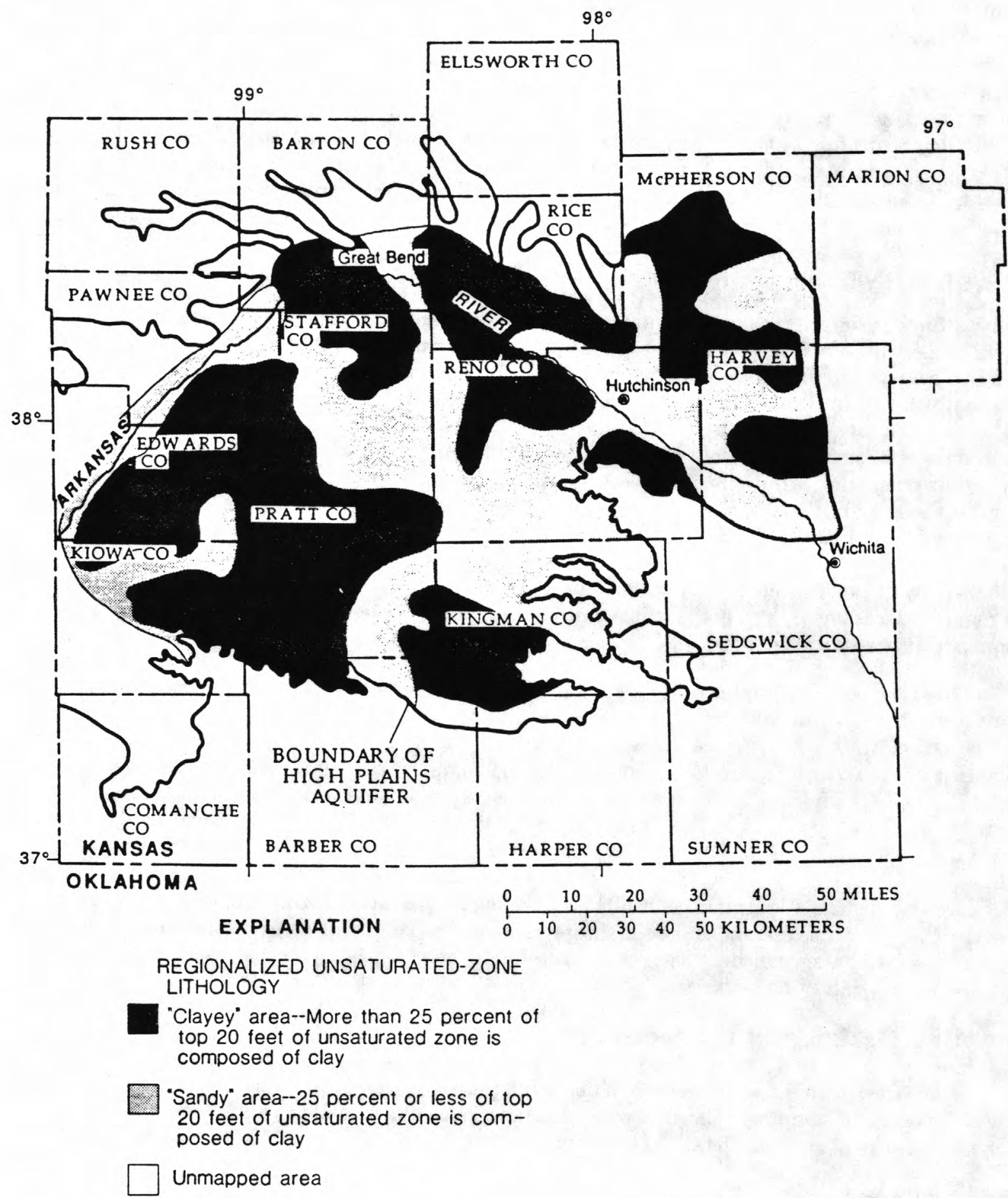

Figure 7. Regionalized unsaturated-zone lithology. 
IRRIGATED CROPLAND

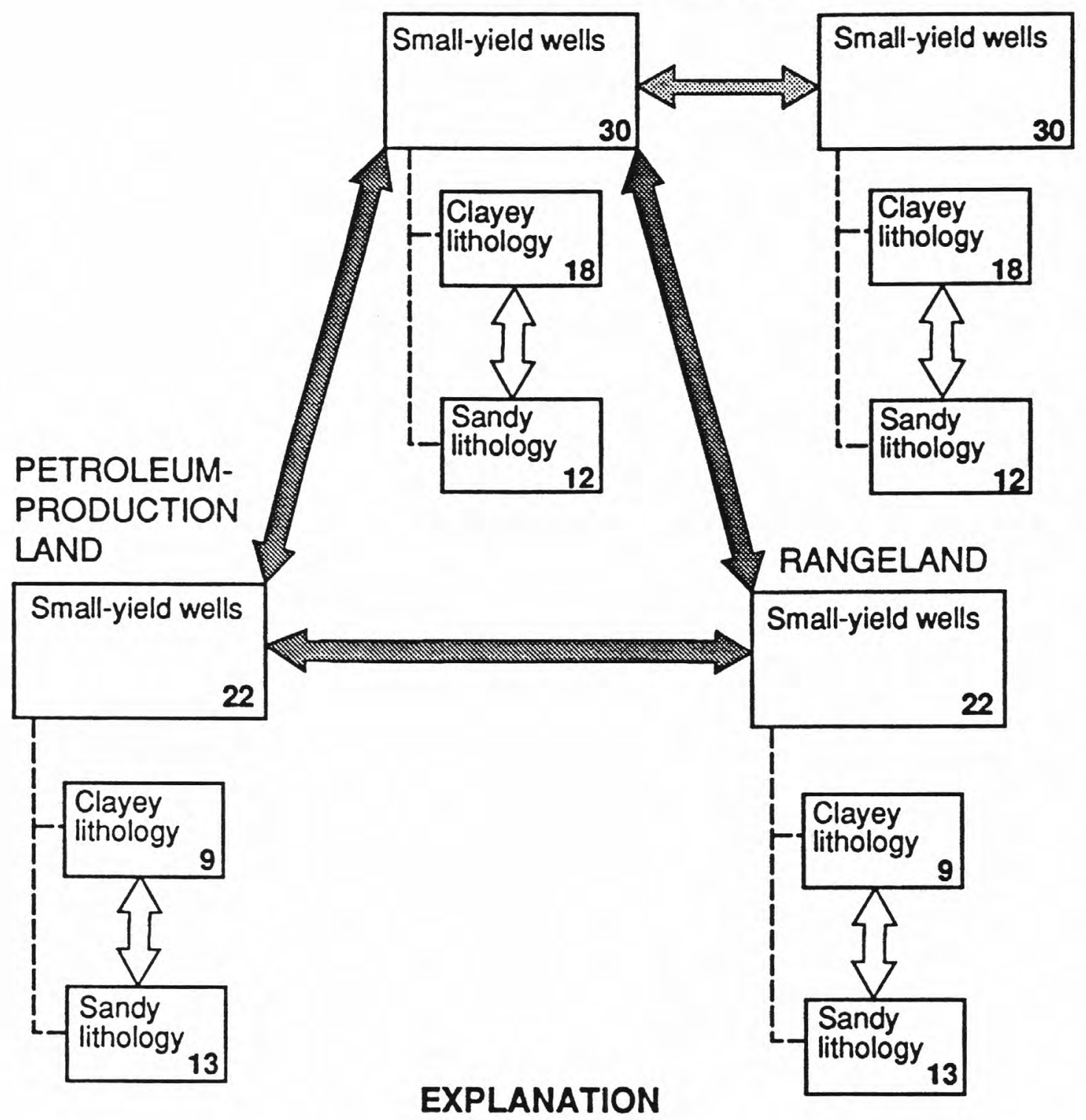

30 GROUPED WATER SAMPLES-

Numeral is number of sampled

wells

PRIMARY STATISTICAL

COMPARISONS AMONG OR

BETWEEN GROUPS

Land use

IV Unsaturated-zone lithology

Type of well sampled

Figure 8. Groupings of water samples for statistical comparisons and number of sampled wells in each group. 
With regard to organic compounds, samples from irrigated cropland were compared with those from undeveloped rangeland for pesticide presence or concentrations, and samples from petroleum-production land were compared with those from undeveloped rangeland for hydrocarbon presence or concentrations. Additionally, comparisons based on unsaturated-zone lithology were included to help recognize its effect on regional ground-water quality. These comparisons, based on land use and unsaturated-zone lithology, were made using samples only from corresponding well types to minimize the effects of well location and yield. The effect of the type of well sampled was evaluated by comparing results from small-yield wells with those from irrigation wells in the areas of irrigated cropland.

In accordance with the rationale just described, one small-yield well in each of the discrete land-use areas (for all categories of land use) was selected randomly for sampling, and one irrigation well in each area of irrigated cropland was selected randomly for sampling. Statistically, the population from which each well was selected in each discrete land-use area consisted of all wells (small-yield or irrigation, as appropriate) in that area for which information is available. This information consists of driller-submitted records for wells constructed after 1975 . The record typically includes location, well depth, construction data, and driller's log. This record enabled verification that a given well was completed in the High Plains aquifer and provided information that could be pertinent to interpreting water-quality results. Although water-quality characteristics could vary with depth of well sampled, well depths in an area tend to be similar, and results are assumed to be representative.

Random-number generation was used to select wells for sampling. If, for a particular land-use area, the well could not be located or could not be sampled for some other reason, a different well was selected according to the random-number assignment. In some areas having only a few wells with recorded information, inability to sample any of the candidate wells necessitated selecting a well arbitrarily in the field for sampling. This entailed recording as much information about the well as possible based on an interview with the well user.

\section{Sampling Procedures}

Sampling was conducted during July 1987 , and began a few weeks after the irrigation season (normally, June-August) had begun. Each well was sampled once. Samples were collected only from wells that could be pumped long enough to ensure that untreated water was being obtained directly from the aquifer. Samples were collected and prepared according to standard procedures developed by Skougstad and others (1979) and sent to the U.S. Geological Survey water-quality laboratory in Arvada, Colorado, for analysis.

At all sampled wells, onsite determinations were made for specific conductance, $\mathrm{pH}$, water temperature, and alkalinity. Also in all cases, samples were collected for laboratory analyses of the major inorganic ions and other inorganic constituents of interest.

Requested laboratory analyses for organic constituents depended on the land-use area in which the sample was collected. In areas of irrigated cropland and rangeland, samples also were collected for analysis of triazine and other nitrogen-containing herbicides, and chlorophenoxy-acid herbicides. These classes of pesticides contain the chemicals most commonly applied and were the only pesticides detected during the 1984 reconnaissance sampling (Stullken and others, 1987). In areas of petroleum-production land and rangeland, samples were collected for analysis by gas chromatography with flame-ionization detection (GC/FID scan). Descriptions of this procedure are given by Feltz and others (1986) and Stullken and others (1987). Without targeting specific organic compounds, the GC/FID scan is used as a screening procedure capable of detecting a variety of organic compounds and is particularly suitable for detection of hydrocarbons. Results provided by the GC/FID scans are only semiquantitative and nonspecific (specific compounds are not identified). Subsequently, gas chromatography with mass spectrometry (GC/MS) was performed on selected samples to attempt identification of the organic compounds detected by the GC/FID scan. 
Data were analyzed by statistical hypothesis tests to identify relations between ground-water quality and land use or other selected factors. Statistical distributions for most chemical constituents were non-normal and positively skewed, and nonparametric procedures were used for statistical testing. The tests applied are described in the following paragraphs.

The two-tailed Wilcoxon-Mann-Whitney rank-sum test (Iman and Conover, 1983) allows statistical comparison of two groups of data. For a given property or constituent, the null hypothesis can be stated that the median values or concentrations of the two groups are equal at a specified confidence level. The alternative hypothesis can be stated that they are not equal. Rank-sum test results, in addition to acceptance or rejection of the null hypothesis at the specified confidence level, indicate at what confidence level the null hypothesis would be rejected. This confidence level provides a measure of similarity or dissimilarity between the two groups. In cases of strong dissimilarity, the group with the larger median value or concentration can be identified by the statistics of the distributions.

Contingency-table analysis is used to help evaluate data that are classified by two criteria (Iman and Conover, 1983). This method is applicable for trace organic constituents in this study because these data are presented in terms of presence or absence. The null hypothesis for this test can be stated that there is no association between a particular factor of interest and the presence or absence of a particular constituent in the ground water at a specified confidence level. The alternative hypothesis can be stated that there is an association.

\section{RESULTS OF DATA ANALYSIS AND STATISTICAL TESTING}

Results of water-quality analyses are given in table 6 at the end of this report and are grouped according to the factors considered--land use, unsaturated-zone lithology, and type of well sampled. Data analyses for inorganic constituents, pesticides, and hydrocarbons are considered separately according to the appropriate statistical-testing procedures. Interpretations of the results are presented in "Discussion of Results."

\section{Inorganic Constituents}

Results of the water-quality analyses show that most ground water in the sampled areas contains dissolved solids of about 100 to $600 \mathrm{mg} / \mathrm{L}$ (milligrams per liter) and that the water is generally hard to very hard (greater than $120 \mathrm{mg} / \mathrm{L}$ as $\mathrm{CaCO}_{3}$ ). The water is commonly a calcium bicarbonate type, but sodium and chloride are predominant ions in some areas.

\section{Comparisons by Land Use}

Examination of some of the statistical data, by land-use area (table 1), indicates that some variation in general ground-water quality might be related to prevailing land use. Boxplots arranged according to land-use area (fig. 9) allow clearer, visual comparisons between medians and overall data distributions. For example, it is apparent that ground-water samples from petroleum-production land exhibit larger median concentrations of dissolved solids, calcium, sodium, and chloride than do samples from irrigated cropland or rangeland. Samples from rangeland exhibit smaller median concentrations of dissolved solids, calcium, sodium, and chloride than do samples from the other two land-use areas.

The rank-sum test (Wilcoxon-Mann-Whitney) was used to compare each pair of the three land-use areas, in terms of median property values ( $\mathrm{pH}$, water temperature, hardness, and alkalinity) and median inorganic-constituent concentrations. The results are illustrated by plotting test confidence levels that exceed 80 percent (fig. 10). For several properties or constituents, these confidence levels exceeded 95 percent, a commonly cited level of confidence that is used in this report 
Table 1. Summary of selected water-quality data grouped according to land-use areas

[Based on data from small-yield wells; units are in milligram per liter; <, less than]

\begin{tabular}{|c|c|c|c|c|c|c|c|c|c|}
\hline \multirow[b]{2}{*}{$\begin{array}{l}\text { Property or } \\
\text { constituent }\end{array}$} & \multicolumn{3}{|c|}{ Irrigated cropland } & \multicolumn{3}{|c|}{ Petroleum-production land } & \multicolumn{3}{|c|}{ Rangeland } \\
\hline & $\begin{array}{l}\text { Maxi- } \\
\text { mum }\end{array}$ & $\begin{array}{l}\text { Mini- } \\
\text { mum }\end{array}$ & Median & $\begin{array}{l}\text { Maxi- } \\
\text { mum }\end{array}$ & $\begin{array}{l}\text { Mini- } \\
\text { mum }\end{array}$ & Median & $\begin{array}{l}\text { Maxi- } \\
\text { mum }\end{array}$ & $\begin{array}{l}\text { Mini- } \\
\text { mum }\end{array}$ & Median \\
\hline $\begin{array}{l}\text { Hardness, as } \\
\mathrm{CaCO}_{\mathrm{g}}\end{array}$ & 520 & 110 & 180 & 570 & 90 & 190 & 710 & 31 & 130 \\
\hline $\begin{array}{l}\text { Alkalinity, total } \\
\text { as } \mathrm{CaCO}_{3}\end{array}$ & 300 & 40 & 150 & 420 & 77 & 160 & 420 & 28 & 100 \\
\hline Dissolved solids & 900 & 140 & 240 & 1,120 & 149 & 335 & 1,300 & 88 & 180 \\
\hline Calcium & 160 & 34 & 60 & 180 & 31 & 64 & 140 & 9.5 & 44 \\
\hline Magnesium & 30 & 3.2 & 7.1 & 35 & 2.5 & 6.6 & 88 & 1.8 & 4.0 \\
\hline Sodium & 100 & 5.8 & 23 & 200 & 8.5 & 32 & 440 & 6.8 & 13 \\
\hline Potassium & 5 & 1 & 3 & 9 & 1 & 2 & 6 & .9 & 2 \\
\hline Sulfate & 440 & 7.8 & 22 & 150 & 9.1 & 16 & 380 & 10 & 15 \\
\hline Chloride & 140 & 2.9 & 14 & 460 & 3.2 & 50 & 620 & 2.7 & 7.9 \\
\hline $\begin{array}{l}\text { Nitrite plus } \\
\text { nitrate }\end{array}$ & 18 & $<.10$ & 6.8 & 23 & .46 & 3.6 & 36 & 1.1 & 3.4 \\
\hline Orthophosphorus & .13 & .01 & .05 & .14 & .01 & .06 & .49 & .01 & .07 \\
\hline
\end{tabular}

to define statistically "significant" differences between groups. At that confidence level, concentrations of hardness, alkalinity, calcium, magnesium, potassium, fluoride, and nitrite plus nitrate are significantly larger beneath areas of irrigated cropland than beneath areas of rangeland. Iron concentrations are significantly larger beneath rangeland than beneath irrigated cropland. Values of $\mathrm{pH}$, and concentrations of hardness, alkalinity, dissolved solids, sodium, and chloride are significantly larger beneath petroleum-production land than beneath rangeland. Concentrations of nitrite plus nitrate are larger beneath irrigated cropland than beneath petroleum-production land. Concentrations of iron are significantly larger beneath petroleum-production land than beneath irrigated cropland.

\section{Comparisons by Unsaturated-Zone Lithology}

Separate comparisons based on unsaturated-zone lithology were made for each land-use category. Because each land-use area is located within a regionally delineated area of either "clayey" or "sandy" unsaturated-zone lithology (as described previously in the "Study Approach and Methods" section), samples from each land-use area were grouped further on this basis. Boxplots of concentrations of major constituents in clayey and sandy areas generally appeared to be similar within any given land-use category. An example set of boxplots is shown for irrigated-cropland data in figure 11. 
EXPLANATION

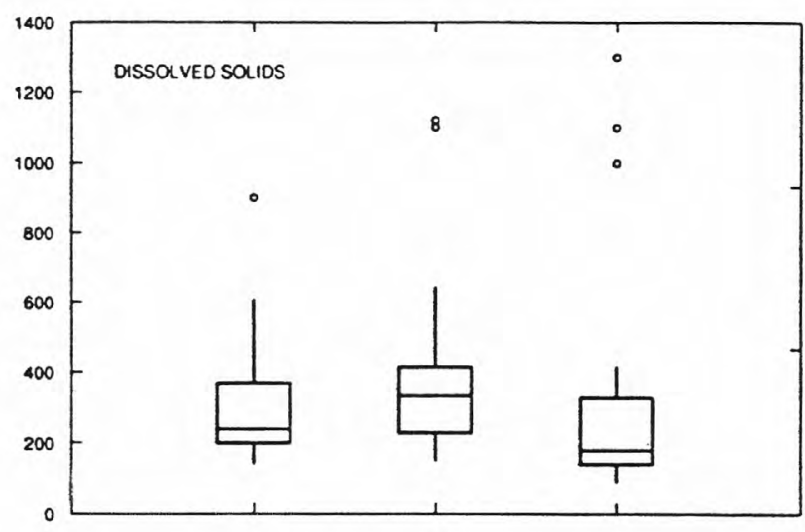

CONCENTRATION FARTHER FROM BOX THAN $3.0 \times$ INTERQUARTILE RANGE

CONCENTRATION FARTHER FROM BOX THAN $1.5 \times$ INTERQUARTILE RANGE
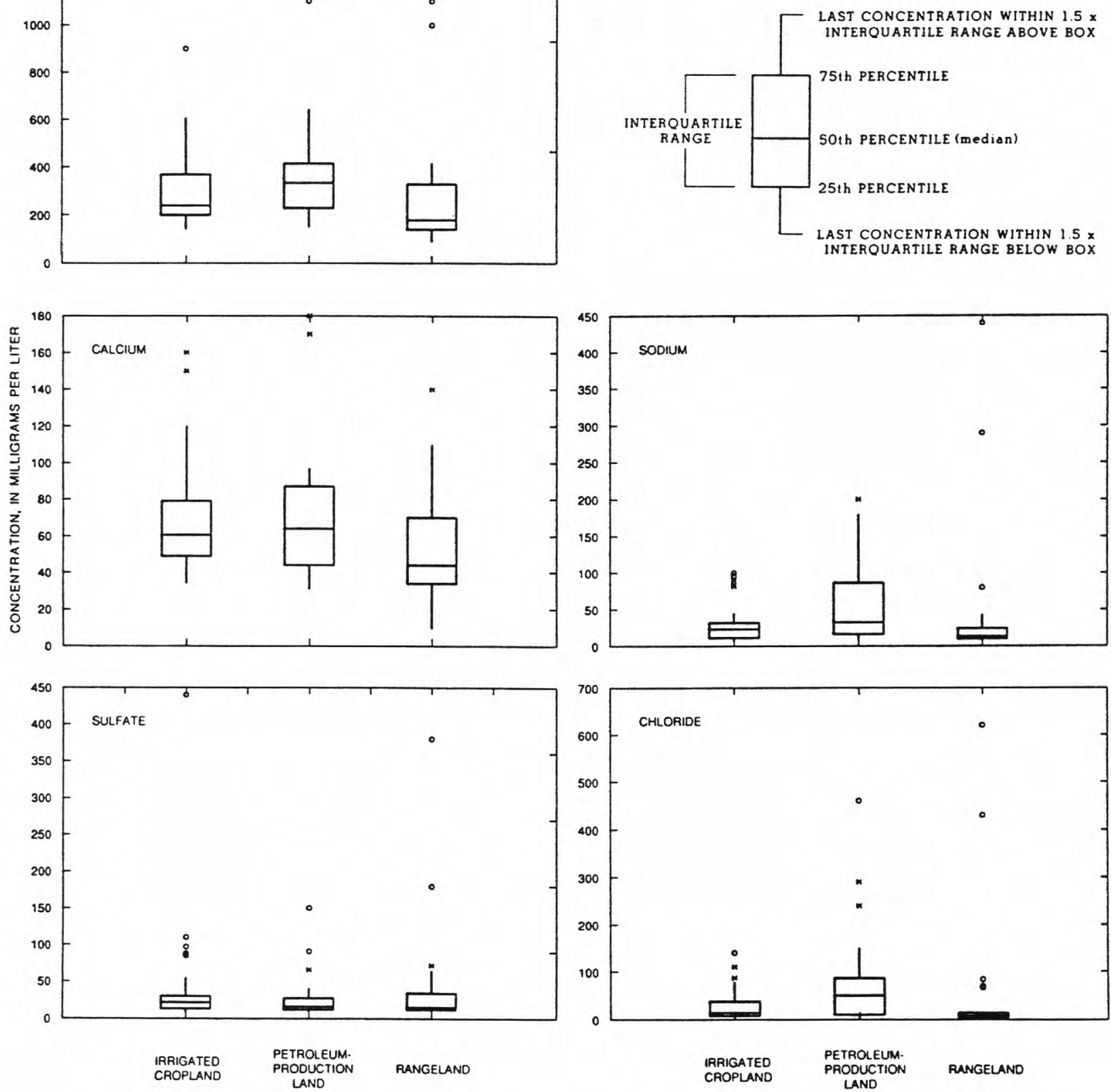

Figure 9. Concentrations of dissolved solids and selected major ions in water samples from small-yield wells grouped according to land-use area (based on 30 irrigated-cropland samples, 22 petroleum-production-land samples, and 22 rangeland samples). 


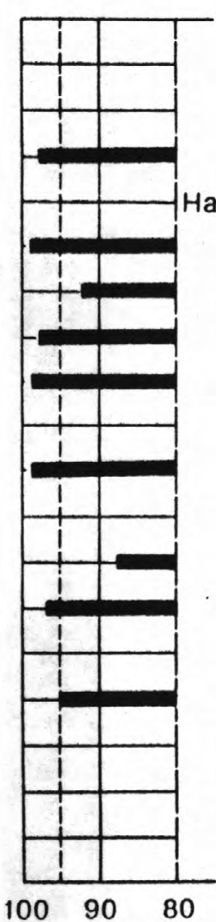

$\mathrm{pH}$

Temperature

Hardness ardness (noncarbonate)

Alkalinity

Dissolved solids

Calcium

Magnesium

Sodium

Potassium

Sulfate

Chloride

Fluoride

Silica

Nitrite plus nitrate

Orthophosphorus

Iron

Manganese

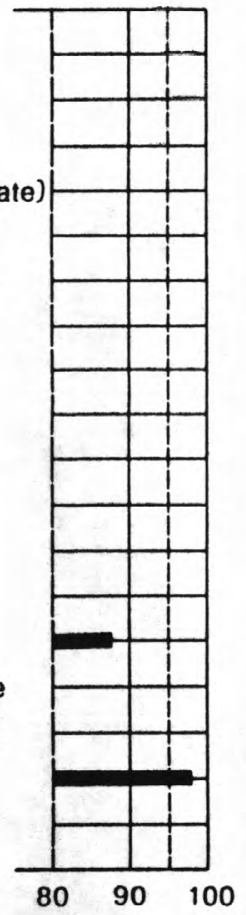

CONFIDENCE LEVEL, IN PERCENT

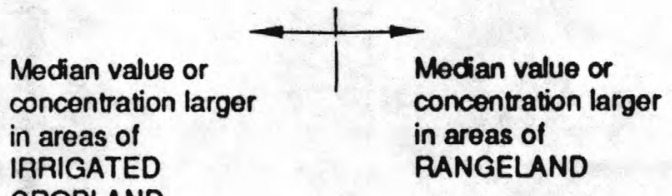

IPRIGAT

CROPLAND

in areas of

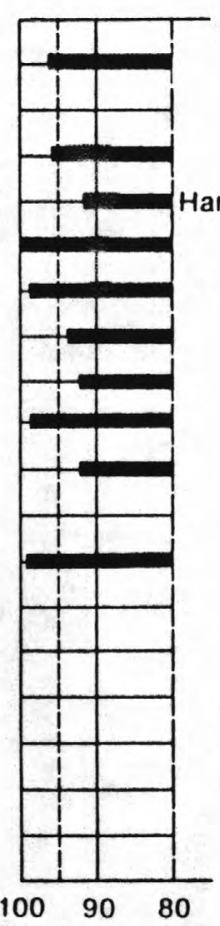

$\mathrm{pH}$

Temperature

Hardness ardness (noncarbonate)

Alkalinity

Dissolved solids

Calcium

Magnesium

Sodium

Potassium

Sulfate

Chloride

Fluoride

Silica

Nitrite plus nitrate

Orthophosphorus

Iron

Manganese

CONFIDENCE LEVEL, IN PERCENT

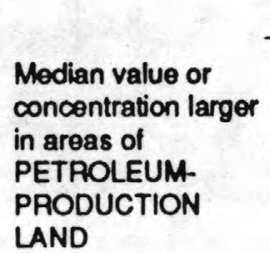

Median value or

concentration larger

in areas of

RANGELAND

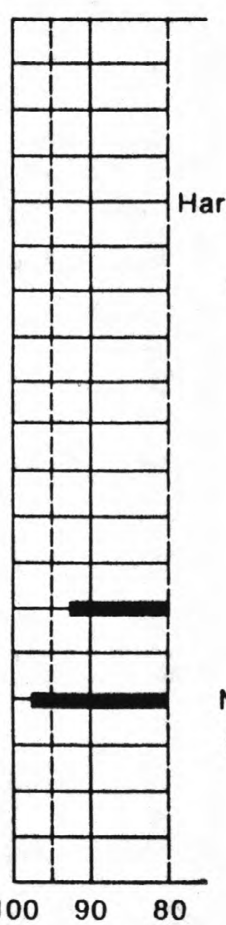

$\mathrm{pH}$

Temperature

Hardness ardness (noncarbonate)

Alkalinity

Dissolved solids

Calcium

Magnesium

Sodium

Potassium

Sulfate

Chloride

Fluoride

Silica

Nitrite plus nitrate

Orthophosphorus

Iron

Manganese

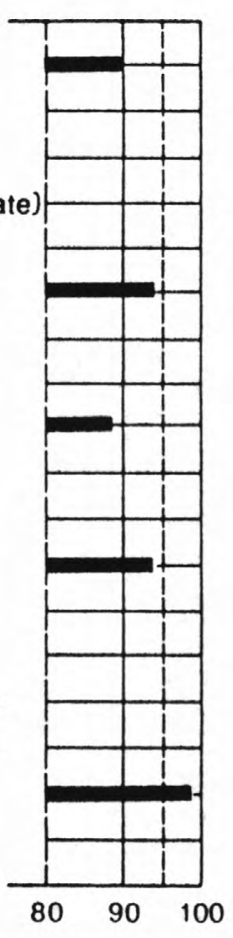

CONFIDENCE LEVEL, IN PERCENT

Median value or concentration larger

in areas of

IRRIGATED

CROPLAND

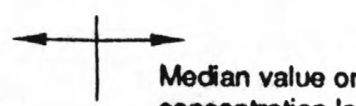
concentration larger in areas of

PETROLEUMPRODUCTION LAND

Figure 10. Confidence levels of differences between median property values or inorganic-constituent concentrations in water samples from small-yield wells in different land-use areas, based two-tailed Wilcoxon-Mann-Whithey rank-sum tests. 


\section{EXPLANATION}

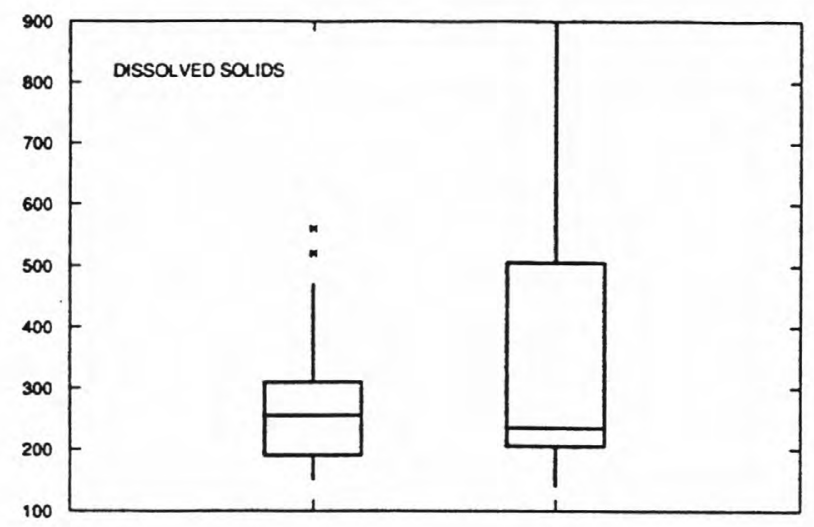

CONCENTRATION FARTHER FROM BOX THAN $3.0 \times$ INTERQUARTILE RANGE

CONCENTRATION FARTHER FROM BOX THAN $1.5 \times$ INTERQUARTILE RANGE
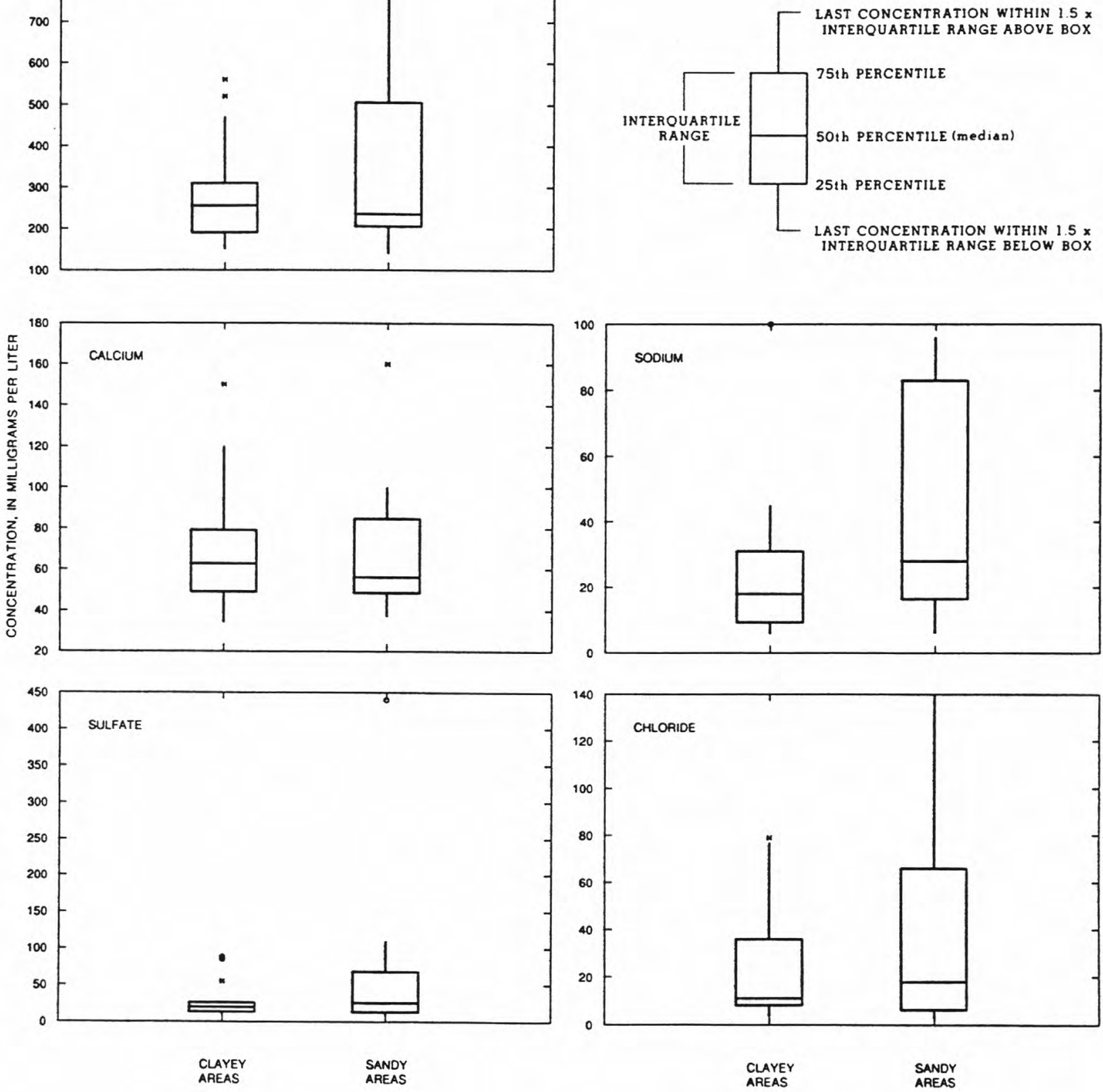

Figure 11. Concentrations of dissolved solids and selected major ions in water samples from small-yield wells in areas of irrigated cropland, grouped according to unsaturated-zone lithology (based on 18 clayey-area samples and 12 sandy-area samples). 
The rank-sum test was used to test for equality of individual water-quality characteristics between clayey and sandy unsaturated-zone areas. Results indicated few statistically significant differences (fig. 12), none of those being major constituents. In areas of irrigated cropland, concentrations of silica and orthophosphorus were significantly larger in clayey areas than in sandy areas. In areas of petroleum-production land, no significant differences were evident between clayey and sandy areas. In areas of rangeland, iron concentrations were indicated to be larger in clayey areas than in sandy areas at the 94-percent confidence level.

Testing of the data representing only irrigation wells in the areas of irrigated cropland revealed two significant differences (fig. 13): (1) $\mathrm{pH}$ was greater in samples from the areas of clayey unsaturated-zone lithology, and (2) noncarbonate hardness was greater in samples from areas of sandy unsaturated-zone lithology.

The lithology factor also was assessed by repeating comparisons between land-use areas according to subdivisions of unsaturated-zone lithology. For the comparison of irrigated-cropland samples with rangeland samples (fig. 10), it was previously noted that concentrations of several major constituents were significantly larger in the irrigated-cropland samples. Rank-sum tests applied only to the data from areas of clayey unsaturated-zone lithology indicate significant differences only for concentrations of nitrite plus nitrate (larger in areas of irrigated cropland) and iron (larger in areas of rangeland) (fig. 14A). Most of the previously noted significant differences, however, remained significant when tests were applied to the data from areas of sandy unsaturated-zone lithology (fig. 14A).

The same procedure was applied for the other two comparisons between land-use areas, petroleum-production land with rangeland, and irrigated cropland with petroleum-production land. As with the comparisons of irrigated cropland with rangeland, most significant differences in the comparisons of petroleum-production land with rangeland were in the areas of sandy unsaturated-zone lithology (fig. 14B). The contrast between areas of clayey and sandy unsaturated-zone lithologies was not evident in the comparisons of irrigated cropland with petroleum-production land (fig. 15). The comparisons of these two land-use areas not divided according to unsaturated-zone lithology (fig. 10) indicated significantly larger concentrations of nitrite plus nitrate in areas of irrigated cropland and significantly larger concentrations of iron in the areas of petroleum-production land.

\section{Comparisons by Type of Well Sampled}

Testing for differences in inorganic ground-water quality according to type of well sampled was limited to the areas of irrigated cropland. Boxplots of concentrations of major constituents, grouped according to type of well sampled, show no obvious contrasts between data from small-yield wells and data from irrigation wells (fig. 16).

The rank-sum test was used to compare values and concentrations in samples from small-yield wells to values and concentrations in samples from irrigation wells within the areas of irrigated cropland (fig. 17). Two significant differences are indicated; values for temperature and concentrations of orthophosphorus are significantly larger in the samples from small-yield wells. Significant differences were not indicated for any other constituents.

\section{Pesticides}

All samples except those from areas of petroleum-production land were analyzed for pesticides (triazine and other nitrogen-containing herbicides and chlorophenoxy-acid herbicides). Of the 82 samples for which these pesticides were analyzed, 12 samples contained at least one detectable pesticide. The number of detections for each pesticide is shown in table 2, grouped according to land-use area, unsaturated-zone lithology, and type of well sampled. It is apparent from this tabulation that frequency of pesticide detection shows a relation to land use; only one detection is noted for 

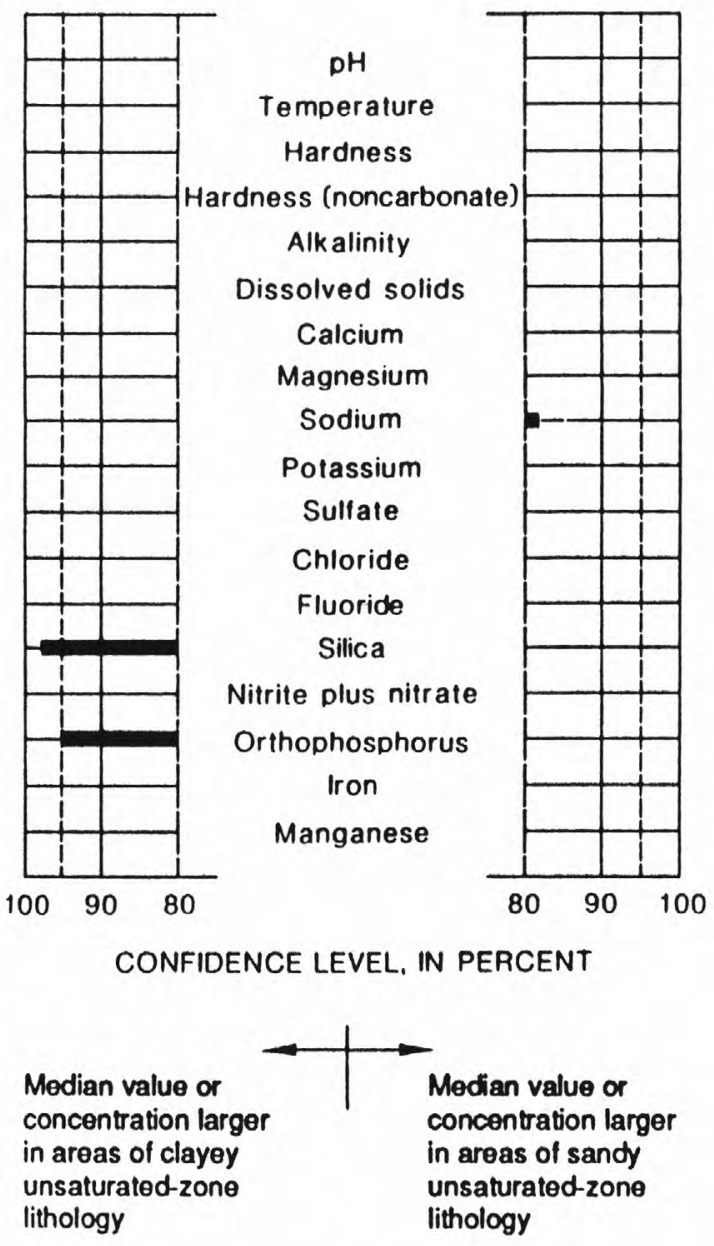

IRRIGATED CROPLAND
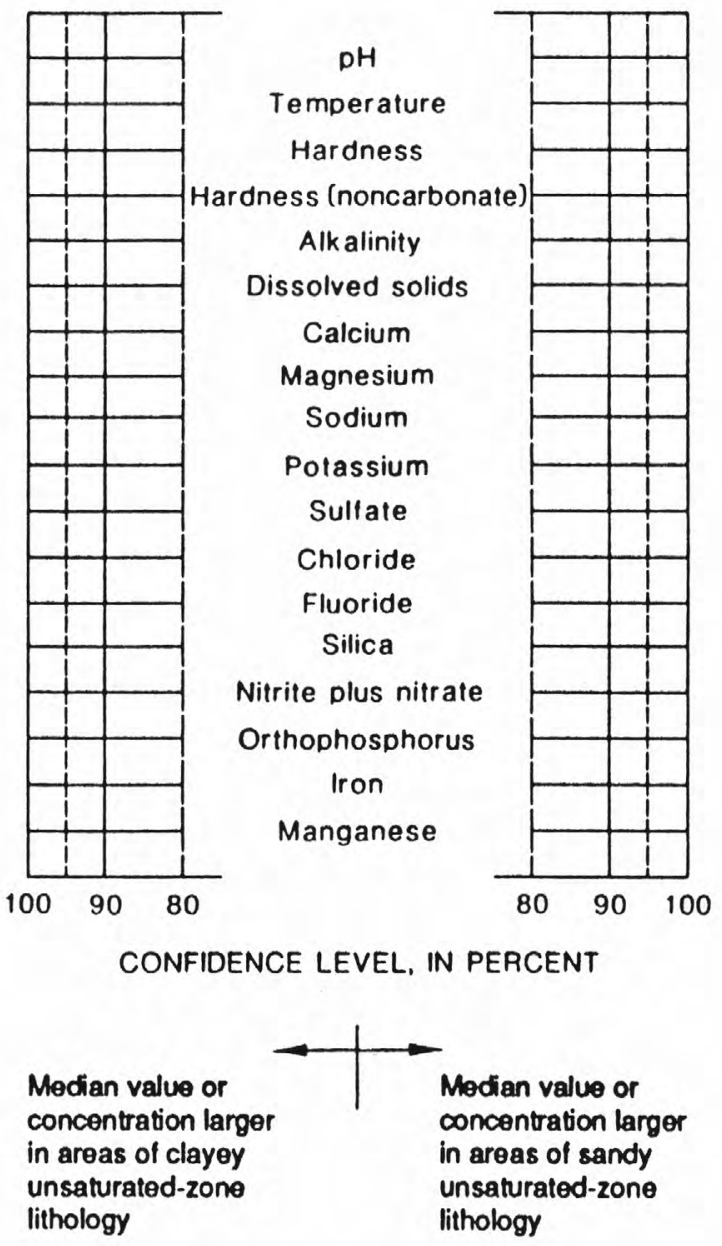

PETROLEUM-PRODUCTION LAND
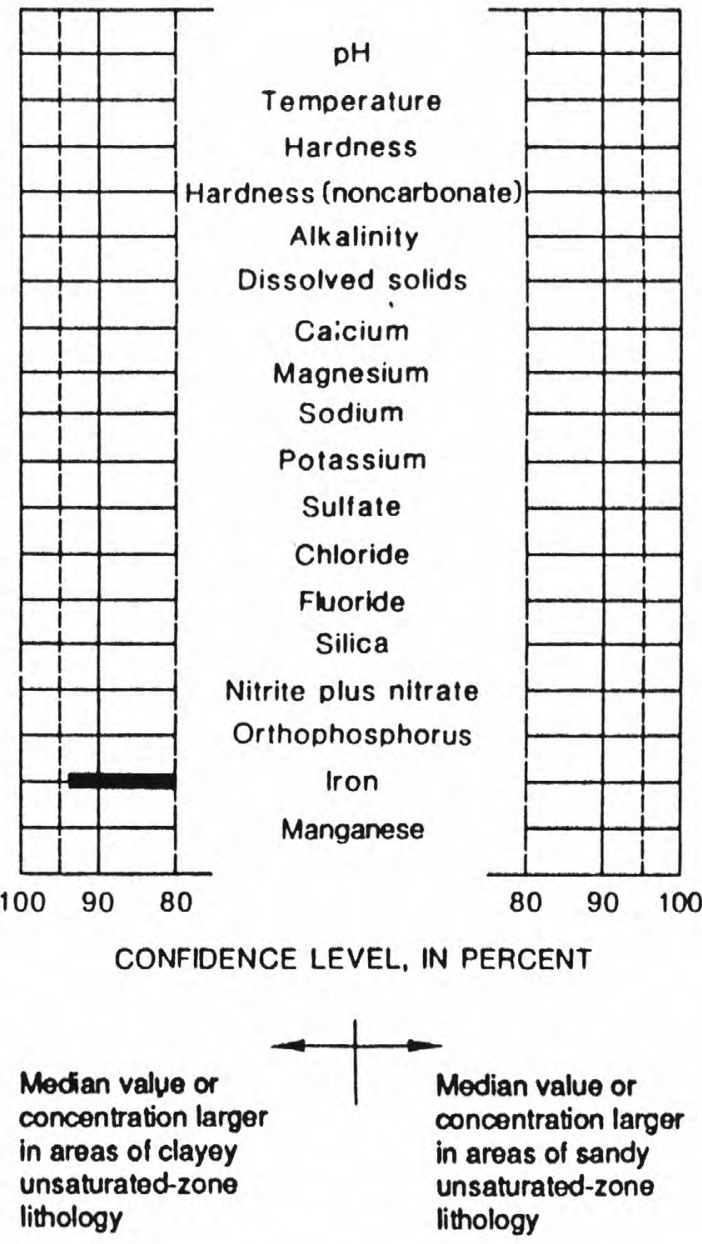

RANGELAND

Figure 12. Confidence levels of differences between median property values or inorganic-constituent concentrations in water samples from small-yield wells in areas of clayey and sandy unsaturated-zone lithology, grouped according to land-use areas and based on two-tailed Wilcoxon-Mann-Whitney rank-sum tests. 


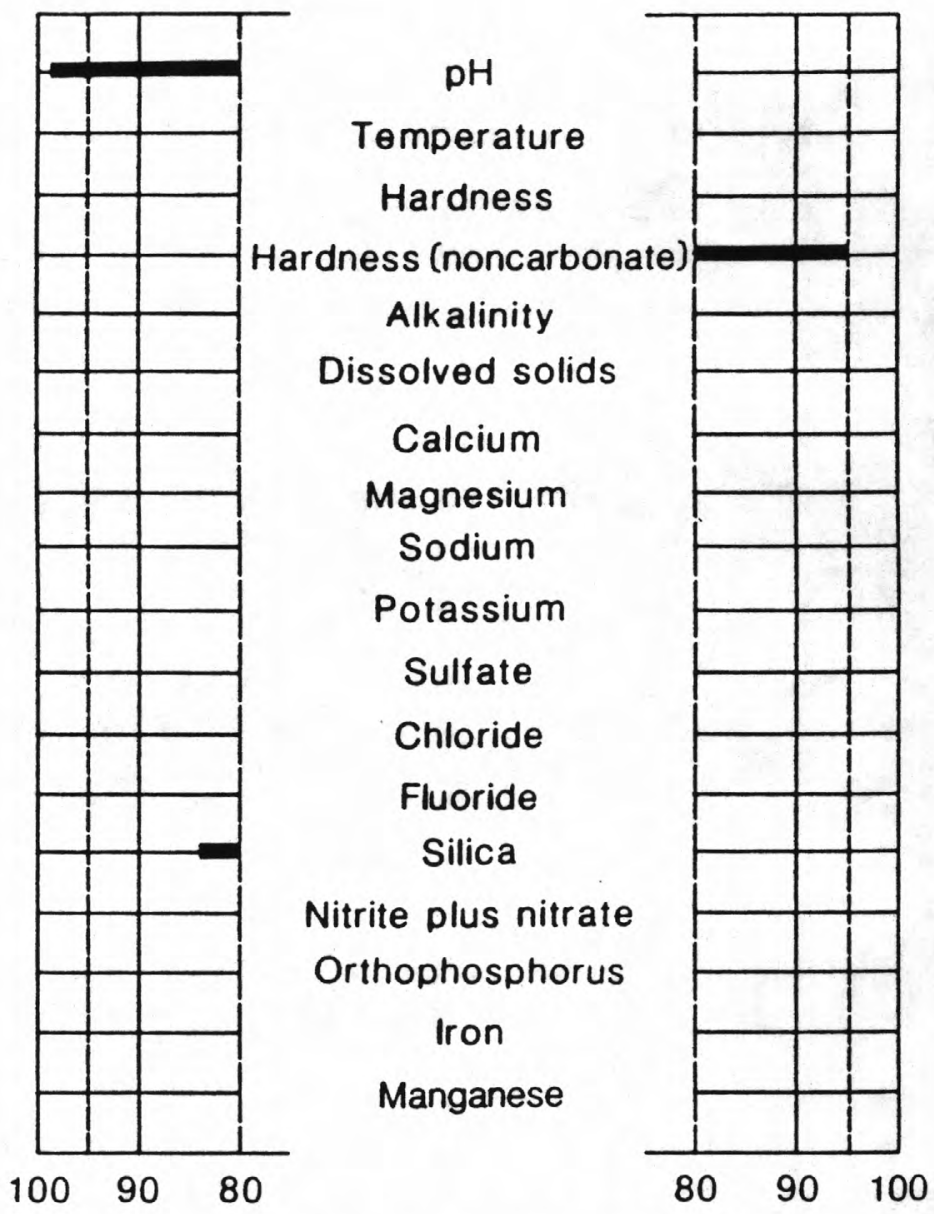

CONFIDENCE LEVEL, IN PERCENT

\author{
Median value or \\ concentration larger \\ in areas of \\ CLAYEY \\ UNSATURATED- \\ ZONE LITHOLOGY
}

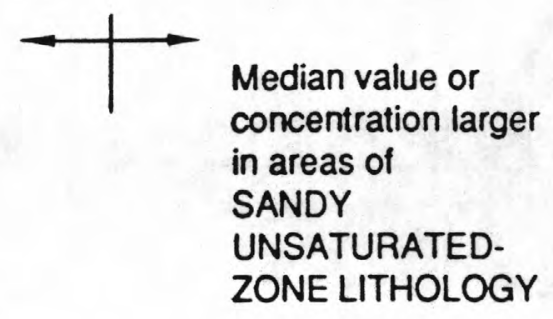

Figure 13. Confidence levels of differences between median property values or inorganic-constituent concentrations in water samples from irrigation wells in areas of clayey and sandy unsaturated-zone lithology, based on two-tailed Wilcoxon-Mann-Whitney rank-sum tests.

rangeland samples. However, any association between pesticide detections and either the unsaturated-zone lithology or the type of well sampled is not evident.

The few numbers of detections made value-based statistical comparisons of pesticides meaningless. Therefore, contingency-table analysis was used for statistical testing. Even when detected, pesticides were present only in trace amounts. Atrazine is the only pesticide that was detected more than twice ( 8 detections) and was present in the largest concentration $(3.8 \mu \mathrm{g} / \mathrm{L})$. The remainder of the "Pesticides" section will be limited to an analysis of atrazine occurrence. The areal distribution of detections and nondetections of atrazine are shown in figure 18. 

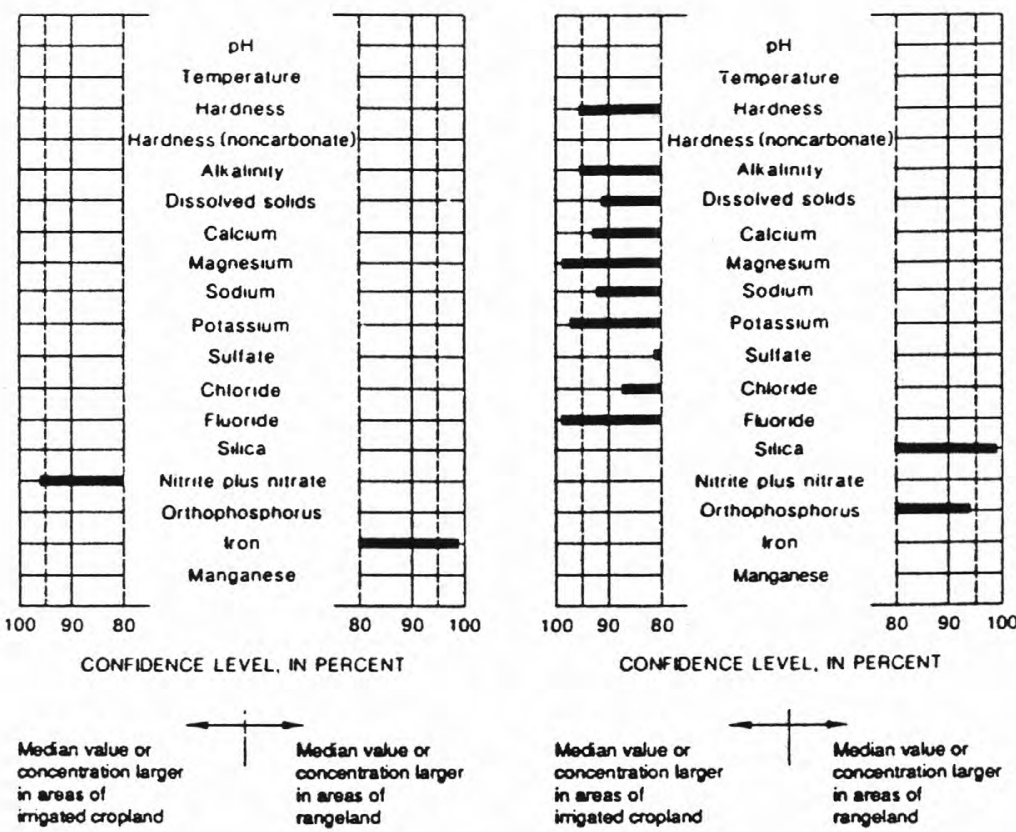

CLAYEY UNSATURATED-ZONE UTHOLOGY

SANDY UNSATURATED-ZONE UTHOLLOY

B. Petroleum-production land and rangeland
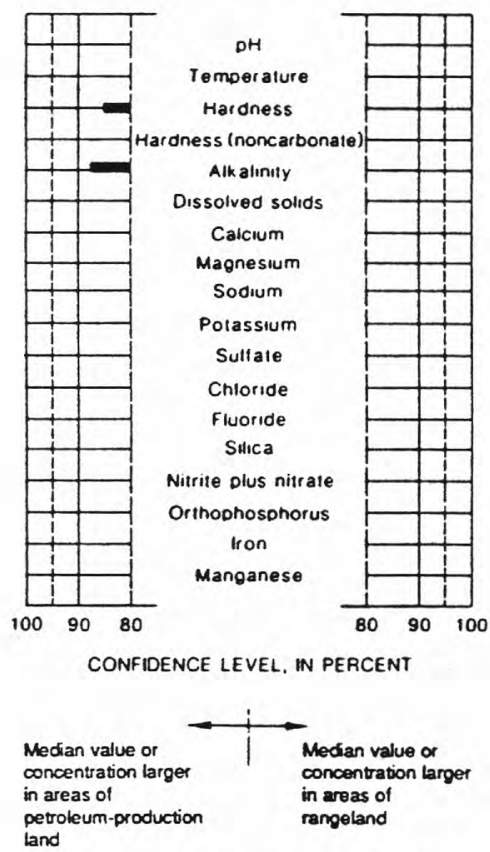

CLAYEY UNSATURATED-ZONE LITHOLOGY

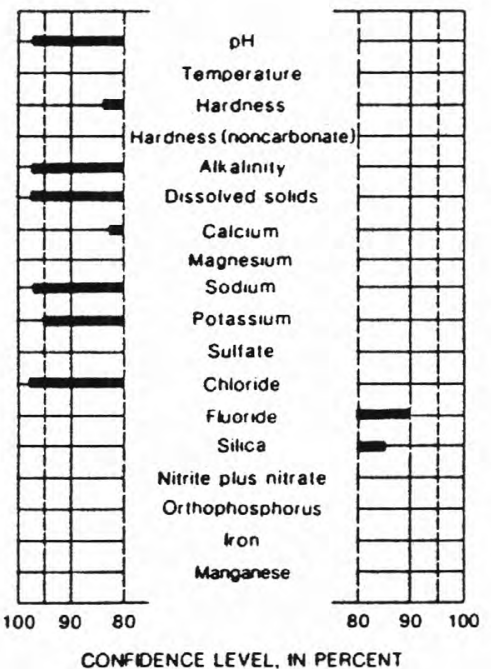

CONFIOENCE LEVEL, IN PERCENT

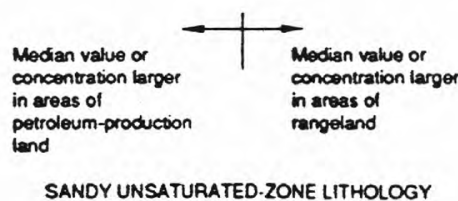

Figure 14. Confidence levels of differences between median property values or inorganic-constituent concentrations in water samples from small-yield wells in different land-use areas, grouped according to unsaturated-zone lithology and based on two-tailed Wilcoxon-Mann-Whitney rank-sum tests. 


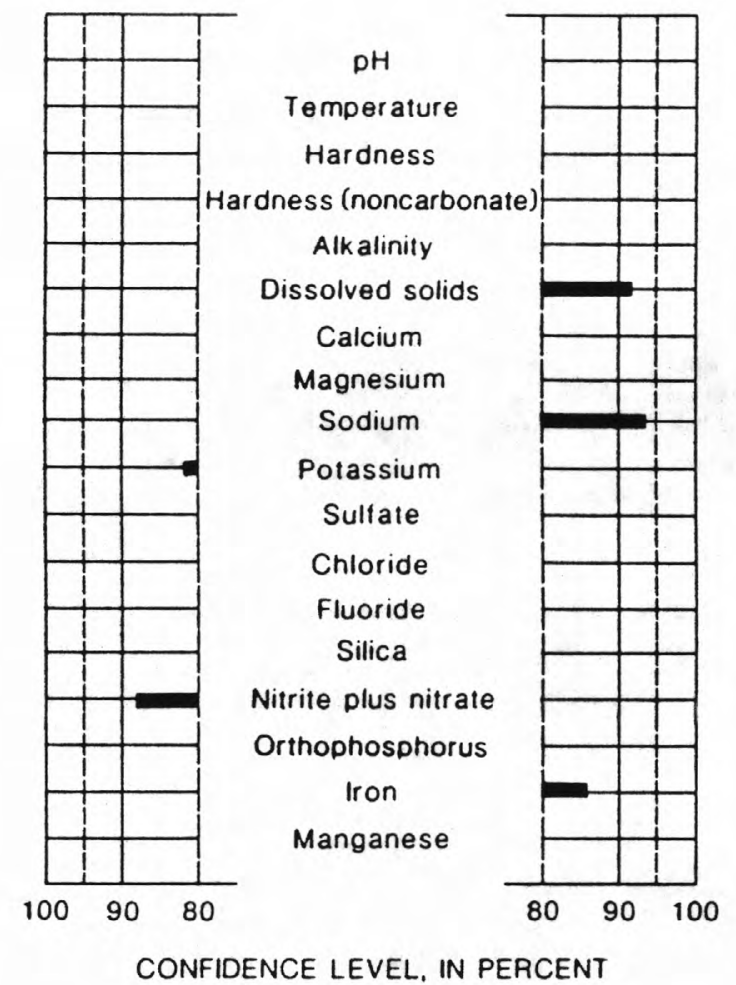

CONFIDENCE LEVEL, IN PERCENT

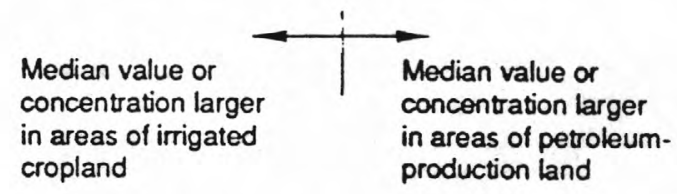

CLAYEY UNSATURATED-ZONE LITHOLOGY

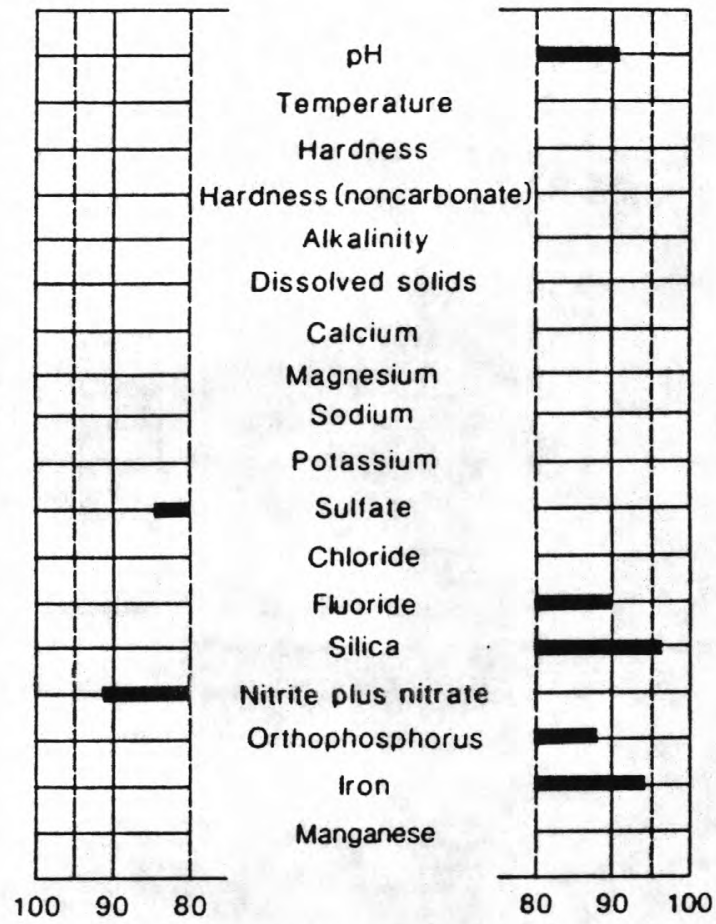

CONFIDENCE LEVEL, IN PERCENT

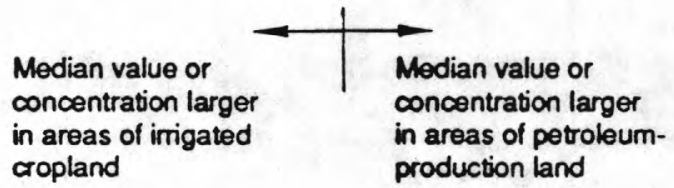

SANDY UNSATURATED-ZONE LITHOLOGY

Figure 15. Confidence levels of differences between median property values or inorganic-constituent concentrations in water samples from small-yield wells in areas of irrigated cropland and

petroleum-production land, grouped according to unsaturated-zone lithology and based on two-tailed Wilcoxon-Mann-Whitney rank-sum tests.

\section{Comparisons by Land Use}

The contingency-table test was used to compare the frequency of atrazine detection beneath irrigated cropland (4 out of 30 samples, according to table 2) to the frequency of detection beneath rangeland (1 out of 22 samples). In accordance with the statistical-comparison framework (fig. 8), data from only small-yield wells but from both types of unsaturated-zone lithology were used. The test concluded a 71-percent confidence level, demonstrating no significant association between atrazine occurrence and use.

Comparisons between land-use areas also were made on the same information divided by unsaturated-zone lithology. No significant difference was indicated between land-use areas with a clayey unsaturated-zone lithology. However, a significant difference (95-percent confidence level) was indicated for areas with a sandy unsaturated-zone lithology; atrazine was detected with greater frequency beneath irrigated cropland ( 3 out of 12 samples) than beneath rangeland ( 0 out of 13 samples). 


\section{EXPLANATION}

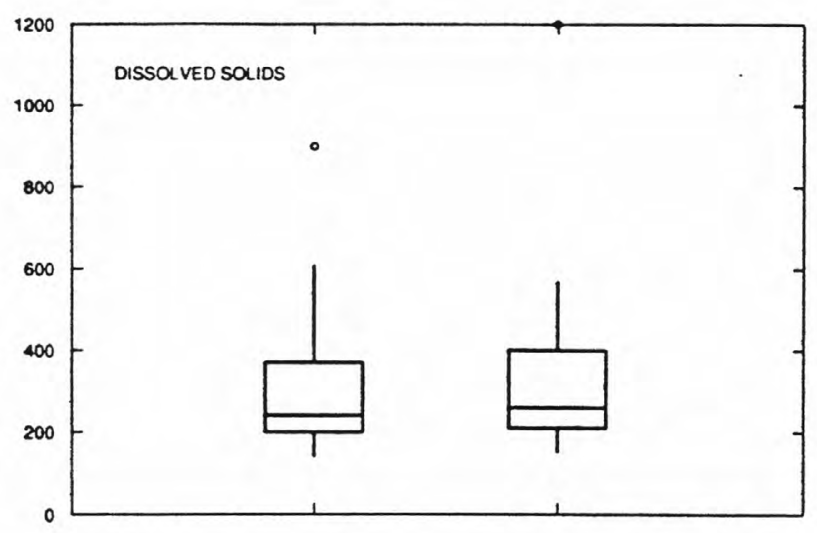

CONCENTRATION FARTHER FROM BOX THAN $3.0 \times$ INTERQUARTILE RANGE

CONCENTRATION FARTHER FROM BOX THAN $1.5 \times$ INTEROUARTILE RANGE
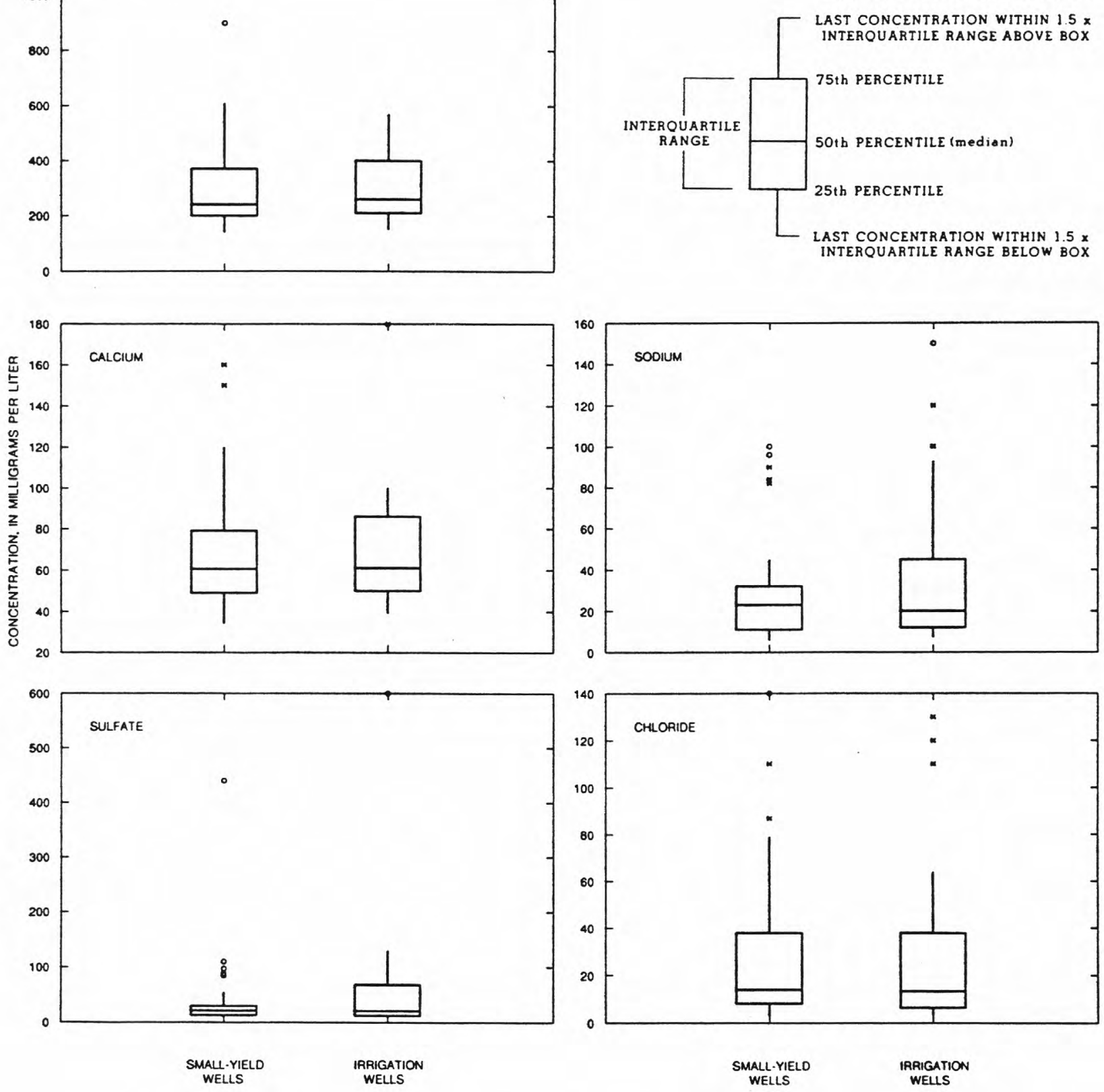

Figure 16. Concentrations of dissolved solids and selected major ions in water samples from wells in areas of irrigated cropland, grouped according to types of well sampled (based on 30 small-yield well samples and 30 irrigation-well samples). 


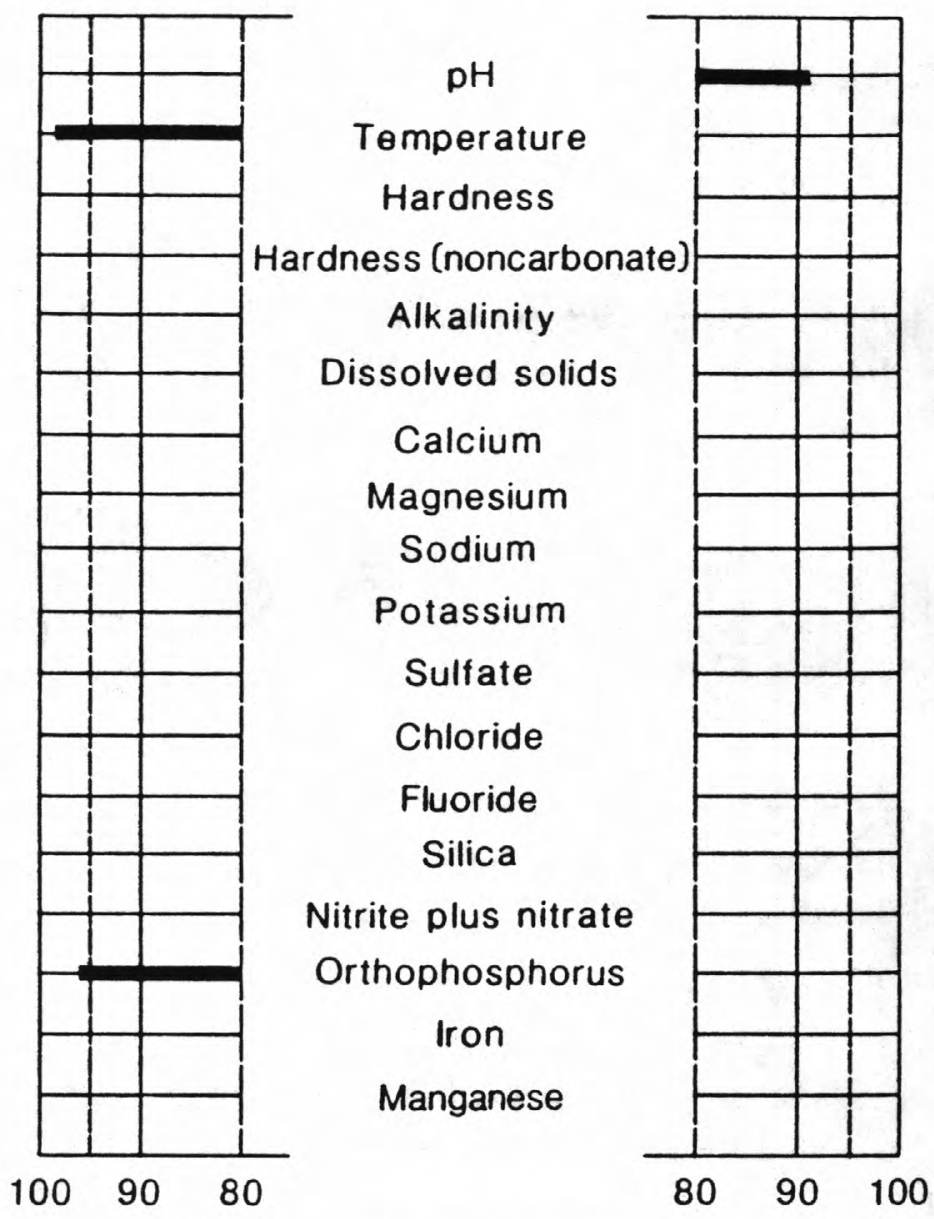

CONFIDENCE LEVEL, IN PERCENT

Median value or concentration larger

in SMALL-YIELD

WELLS

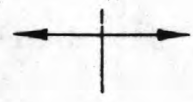

Median value or concentration larger in IRRIGATION WELLS

Figure 17. Confidence levels of differences between median property values or inorganic-constituent concentrations in water samples from small-yield wells and irrigation wells in areas of irrigated cropland, based on two-tailed Wilcoxon-Mann-Whitney rank-sum tests.

\section{Comparisons by Unsaturated-Zone Lithology}

Contingency-table tests were used to make comparisons of the frequencies of atrazine detection in areas of irrigated cropland according to unsaturated-zone lithology. Comparisons indicated no significant associations with this factor. Testing of the results from rangeland for this factor was not appropriate because of an insufficient number of atrazine detections.

\section{Comparisons by Type of Well Sampled}

The contingency-table test was used to compare the frequency of atrazine detection in samples from small-yield wells to the frequency of detection in samples from irrigation wells (using results from areas of irrigated cropland). The test concluded a 69-percent confidence level, demonstrating no significant association between atrazine occurrence and type of well sampled. Testing of the data 
Table 2. Frequency of detections of pesticides in ground-water samples grouped according to land-use areas, unsaturated-zone lithology, and type of well sampled

\begin{tabular}{|c|c|c|c|c|c|c|c|c|}
\hline $\begin{array}{l}\text { Land-use area } \\
\text { (type of well sampled) }\end{array}$ & $\begin{array}{l}\text { Number } \\
\text { of } \\
\text { samples }\end{array}$ & Alachlor & Atrazine & $\begin{array}{l}\text { Meto- } \\
\text { lachlor }\end{array}$ & $\begin{array}{l}\text { Propa- } \\
\text { zine }\end{array}$ & $\begin{array}{l}\text { Triflu- } \\
\text { ralin }\end{array}$ & 2,4-D & $\begin{array}{l}\text { Other triazine } \\
\text { and } \\
\text { chlorophenoxy- } \\
\text { acid herbicides }\end{array}$ \\
\hline \multicolumn{9}{|l|}{ All data } \\
\hline \multicolumn{9}{|l|}{ Irrigated cropland } \\
\hline (small-yield wells) & 30 & 0 & 4 & 0 & 1 & 1 & 1 & 0 \\
\hline (irrigation wells) & 30 & 1 & 3 & 2 & 1 & 1 & 0 & 0 \\
\hline Rangeland & 22 & 0 & 1 & 0 & 0 & 0 & 0 & 0 \\
\hline \multicolumn{9}{|l|}{$\begin{array}{l}\text { Clayey unsaturated-zone } \\
\text { lithology }\end{array}$} \\
\hline \multicolumn{9}{|l|}{ Irrigated cropland } \\
\hline (small-yield wells) & 18 & 0 & 1 & 0 & 1 & 0 & 1 & 0 \\
\hline (irrigation wells) & 18 & 0 & 2 & 1 & 1 & 1 & $\mathbf{0}$ & 0 \\
\hline Rangeland & 9 & 0 & 1 & 0 & 0 & 0 & 0 & 0 \\
\hline \multicolumn{9}{|l|}{$\begin{array}{l}\text { Sandy unsaturated-zone } \\
\text { lithology }\end{array}$} \\
\hline \multicolumn{9}{|l|}{ Irrigated cropland } \\
\hline (small-yield wells) & 12 & 0 & 3 & 0 & 0 & 1 & 0 & 0 \\
\hline (irrigation wells) & 12 & 1 & 1 & 1 & 0 & 0 & 0 & 0 \\
\hline Rangeland & 13 & 0 & 0 & 0 & 0 & 0 & 0 & 0 \\
\hline
\end{tabular}




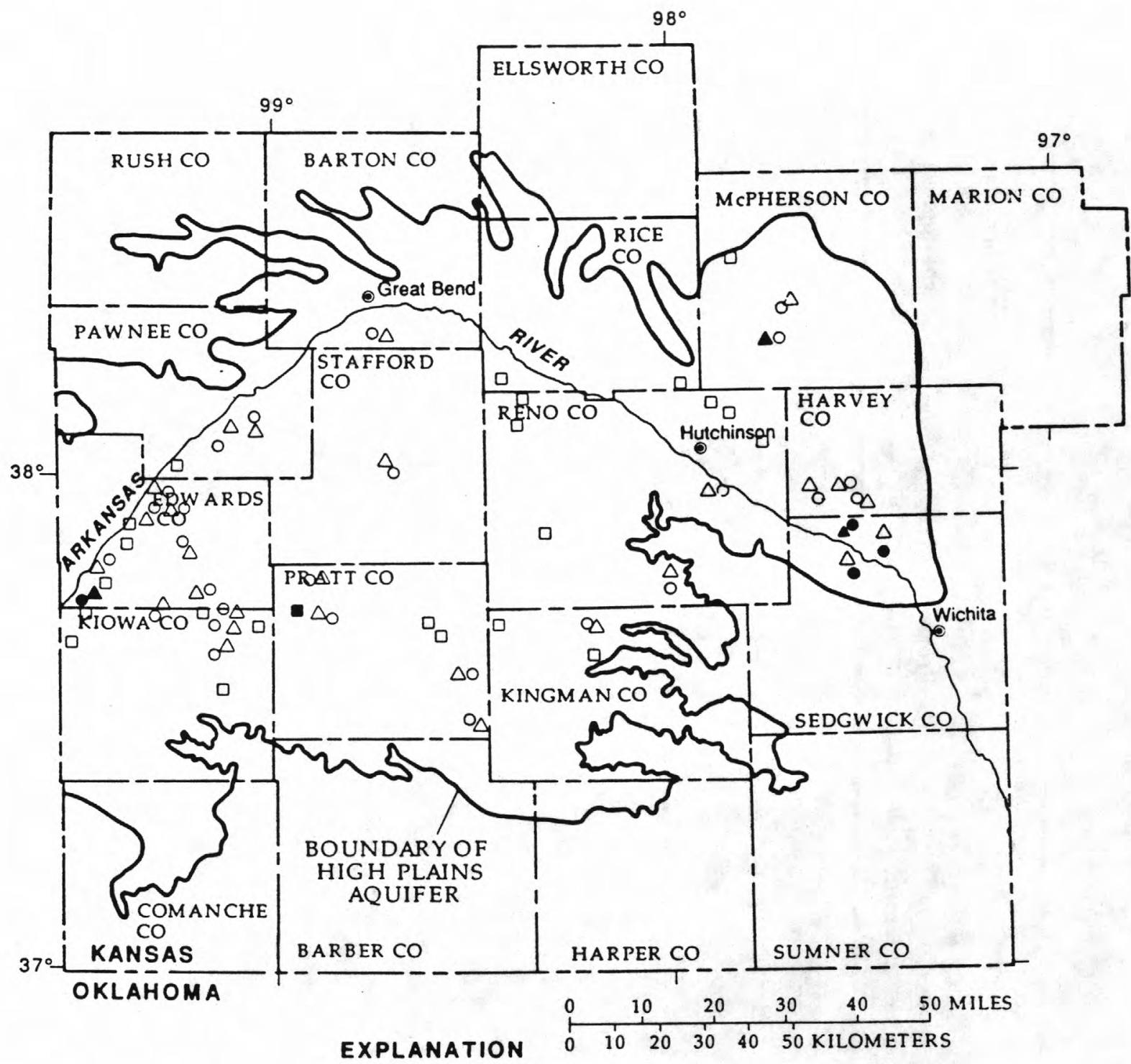

- O SAMPLE FROM IRRIGATED CROPLAND-.Small-yield (domestic or stock) well. Solid circle indicates concentration greater than atrazine detection level; open circle indicates concentration less than atrazine detection-level

$\Delta \triangle$ SAMPLE FROM IRRIGATED CROPLAND--Large-yield (irrigation) well. Solid triangle indicates concentration greater than atrazine detection level; open triangle indicates concentration less than atrazine detection level

- $\quad$ SAMPLE FROM RANGELAND--Small-yield (domestic or stock) well. Solid square indicates sample concentration greater than atrazine detection level; open square indicates concentration less than atrazine detection level

(NOTE: Atrazine detection level is 0.10 microgram per liter)

Figure 18. Location of detections and nondetections of atrazine in ground-water samples. 
divided according to unsaturated-zone lithology likewise indicated no significant association with type of well sampled for areas of either clayey or sandy unsaturated-zone lithology.

\section{Hydrocarbons}

GC/FID scans were made on methylene-chloride extracts of the 22 samples from areas of petroleum-production land and of 23 samples from areas of rangeland (one additional rangeland sample was analyzed by GC/FID, as compared with analyses for inorganic constituents and pesticides). Selected samples were analyzed by GC/MS; however, the very small concentrations prevented specification of compounds. Therefore, this effort focused on the output from the GC/FID method, mainly GC/FID chromatograms, which were analyzed in several ways to evaluate hydrocarbon occurrence in ground water in the study area.

\section{Chromatogram Interpretation}

An example chromatogram for one of the samples is shown in figure 19. The horizontal axis represents retention time of elution (heavier compounds, those with greater molecular weight, generally elute later than lighter compounds). Each peak represents an individual compound. The area under a peak (and, for practical purposes, vertical height of the peak) is proportional to the concentration of the compound represented by the peak.

Interpretation of GC/FID scan results was based on analysis of the chromatograms themselves and information from the laboratory report. Descriptions of this information are given in the following paragraphs, and comparisons based on the information are discussed in succeeding sections.

Total concentrations of methylene-chloride-extractable compounds in a sample were estimated from the total area under the peaks on a chromatogram (excluding surrogate and internal-standard compounds added to the sample at the laboratory). These estimates (concentrations as perdeuteronaphthalene) were reported by the laboratory and ranged from 3.3 to $14 \mathrm{\mu g} / \mathrm{L}$ in samples from areas of petroleum-production land and from 1.2 to $15 \mu \mathrm{g} / \mathrm{L}$ in samples from areas of rangeland.

Frequencies of occurrence of individual compounds also were studied by assuming that each peak at a particular retention time represented the same compound. Presence of a specific compound in a collected sample was defined by whether its peak height was at least three times the height of corresponding peaks, if they existed, in the chromatograms of the laboratory-blank samples (fig. 20). Although arbitrary, this approach was presumed to identify compounds truly present in the collected sample.

Data describing relative heights of individual peaks on chromatograms also were compiled and analyzed as being representative of relative concentrations in the water. Peak heights were measured above the baseline of the chromatogram with the use of an arbitrary, but consistent scale (fig. 21).

\section{Comparisons by Land Use}

The occurrence of hydrocarbons in relation to land use was evaluated first in terms of total concentrations of organic compounds as estimated based on total area under the peaks of the chromatograms. Boxplots (fig. 22) illustrate very similar distributions between total concentrations of organic compounds in samples from areas of petroleum-production land and samples from areas of rangeland, although median and quartile concentrations are larger in the petroleum-production-land samples than in the rangeland samples. The distributions were non-normal and positively skewed; the rank-sum test was applied for statistical testing. The conclusion of equality was accepted at the 95-percent confidence level, the difference being concluded at the 84-percent confidence level.

The frequency of occurrence of individual peaks (specific compounds) also was compared between two land-use areas (fig. 23), and the descriptions reveal only minor differences. The samples 
焉

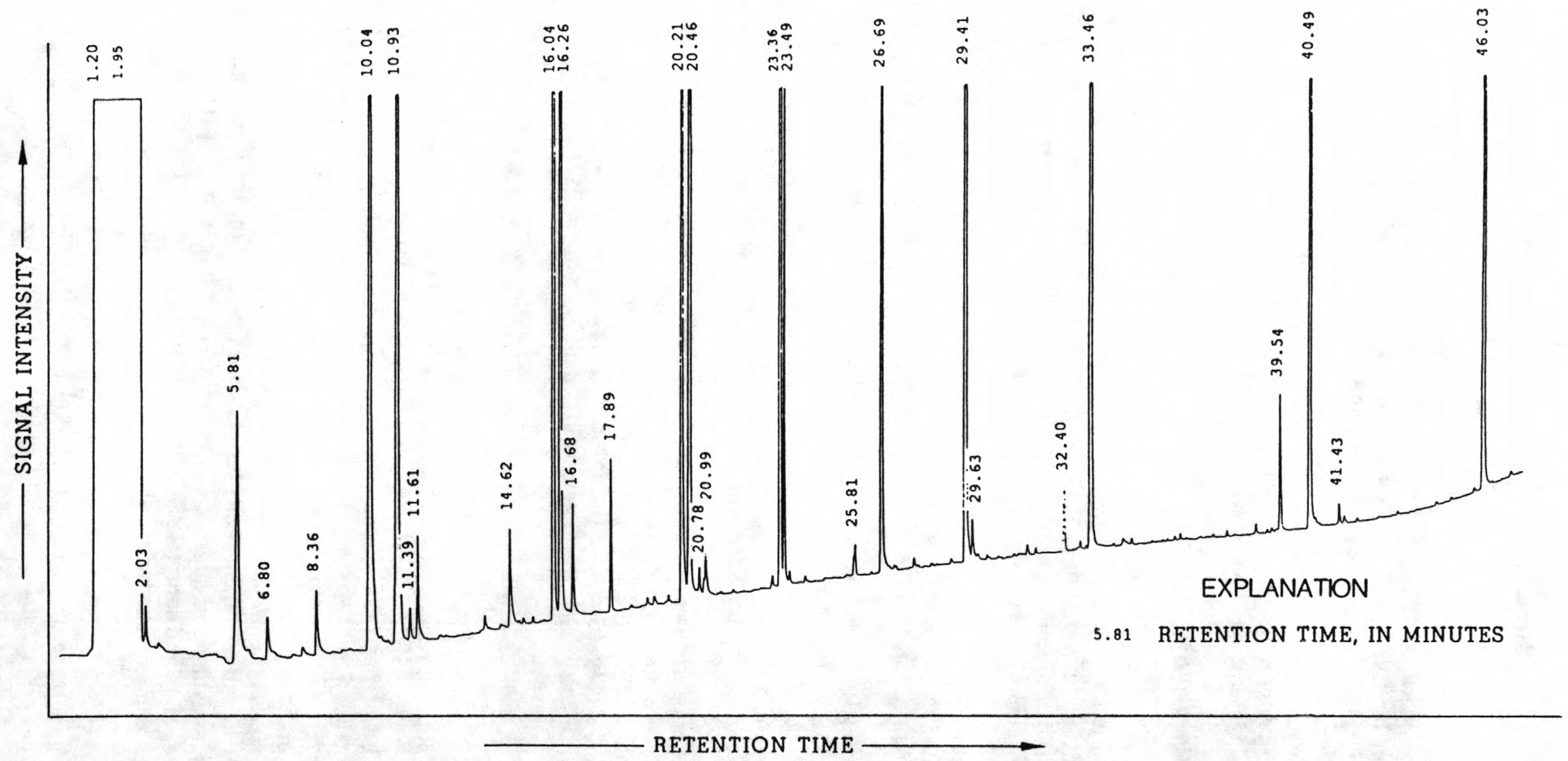

Figure 19. Example of chromatogram produced from analysis of ground-water sample by gas chromatography with flame-ionization detection (GC/FID). 


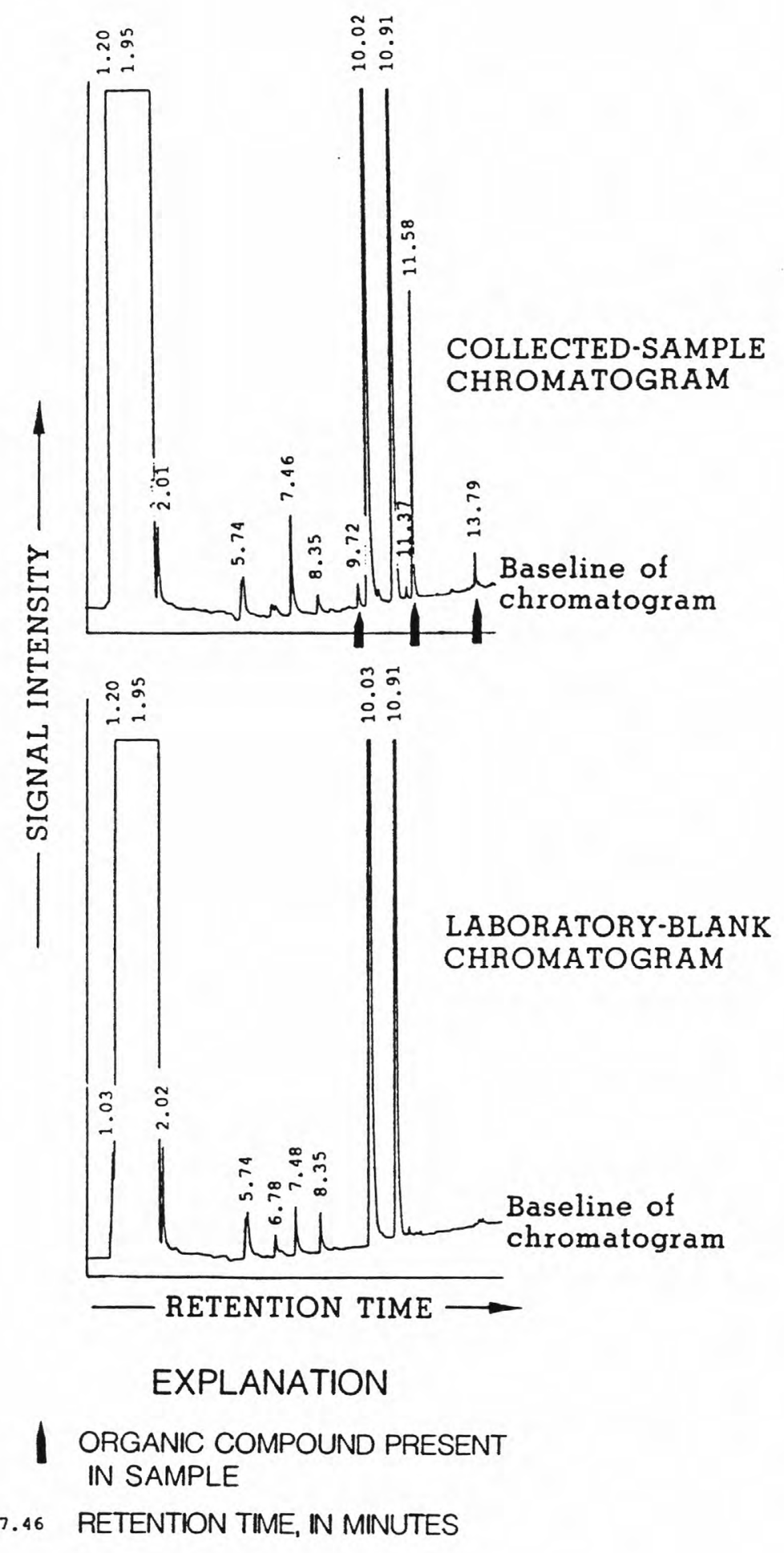

Figure 20. Chromatograms for a collected sample and a laboratory blank that were compared to identify peaks representing organic compounds present in ground water. 


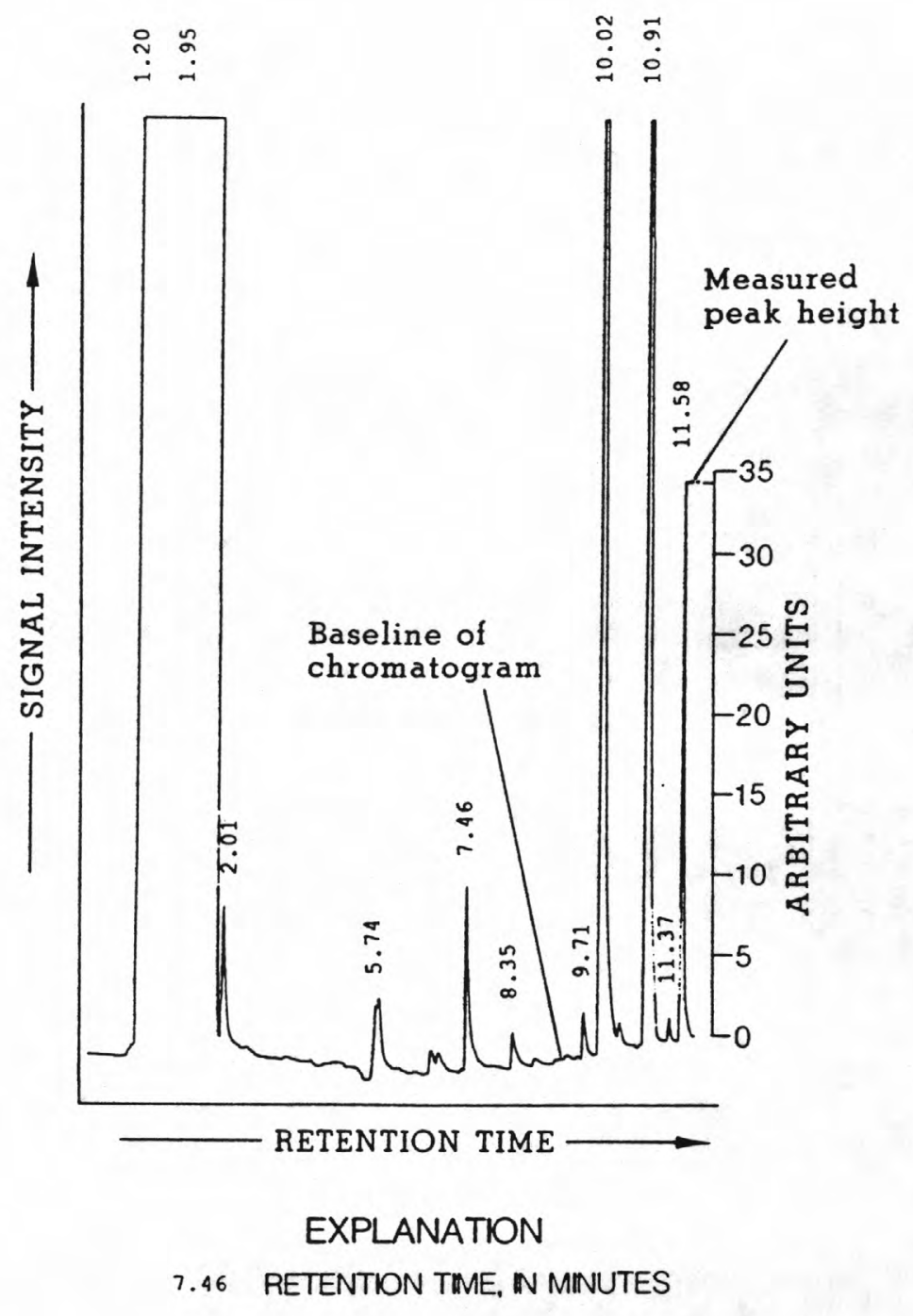

Figure 21. Chromatogram for a collected sample and method of measuring peak height to represent relative concentration of organic compound.

from areas of petroleum-production land showed a slightly smaller range of retention times and perhaps more of a tendency toward the presence of lighter compounds (smaller retention times) than the samples from areas of rangeland. Contingency-table analyses were used to test for association between land use and presence or absence of individual compounds. Significant associations (95-percent confidence level) were indicated for two specific compounds. The compounds with retention times of 13.79 and 16.68 minutes occurred more frequently in samples from areas of petroleum-production land than in those from areas of rangeland (fig. 23). At the 92-percent confidence level, the compounds with retention times of $19.23,21.83$, and 30.93 minutes occurred more frequently in samples from areas of rangeland than in those from areas of petroleum-production land (fig. 23).

Relative peak heights for specific compounds also provided a means of comparison between land-use areas by using the rank-sum test. Although a large number of nondetections of most compounds limits the strength of the tests, a significant difference in peak height was indicated for one compound. This compound, with a retention time of 16.68 minutes, had higher peak heights (larger concentrations) in samples from the areas of petroleum-production land than in samples from the areas of rangeland. This compound is one of the two compounds detected with a significantly greater 


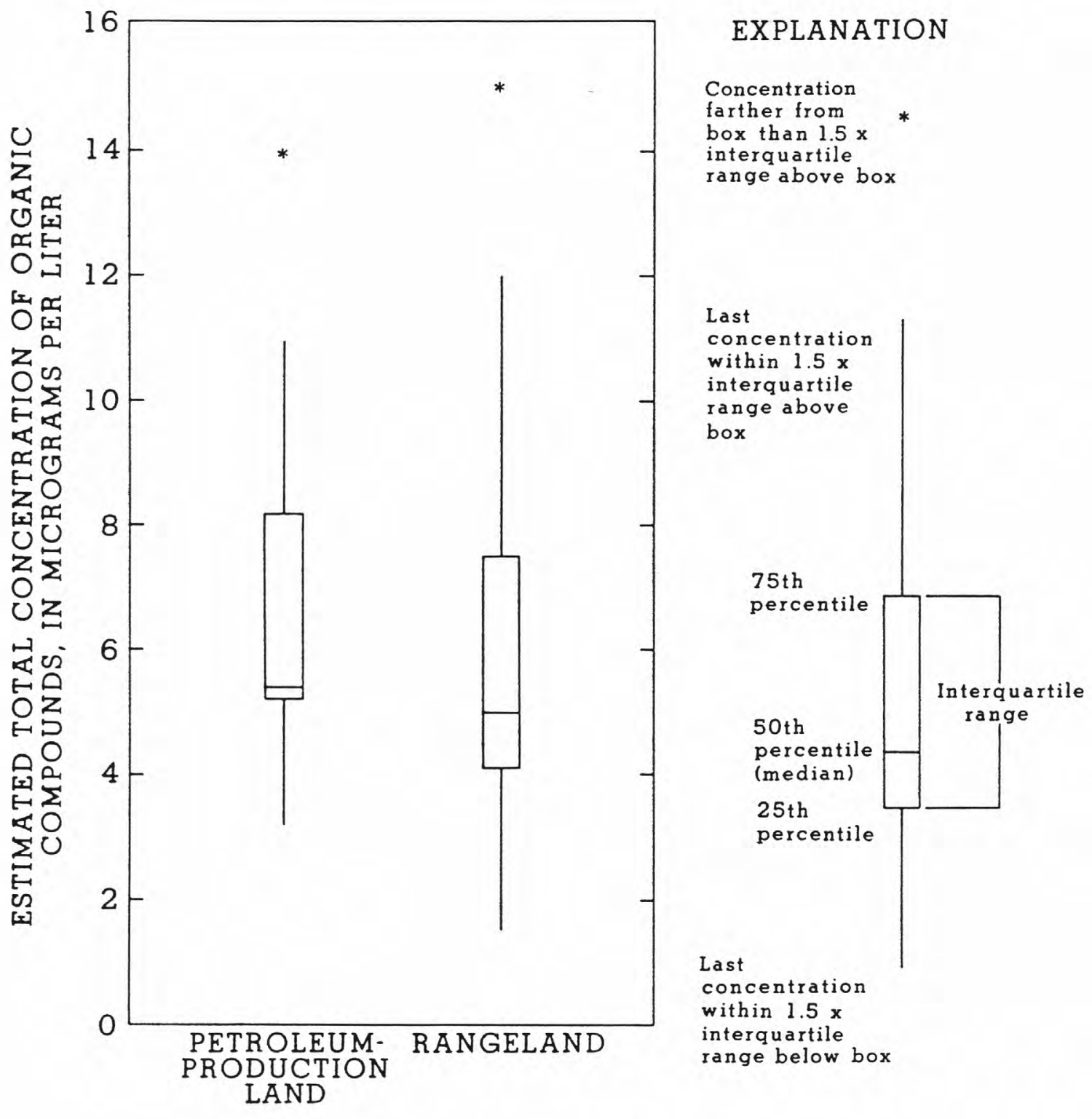

Figure 22. Estimated total concentrations of organic compounds in ground-water samples from areas of petroleum-production land and rangeland (based on 22 petroleum-production-land samples and 23 rangeland samples).

frequency in areas of petroleum-production land according to the contingency-table analysis just described.

\section{Comparisons by Unsaturated-Zone Lithology}

Possible relations between hydrocarbon occurrence and unsaturated-zone lithology were considered by dividing data previously compared only by land use. Total organic-compound concentrations (as estimated from total area under peaks) were compared by the rank-sum test between areas of clayey and sandy unsaturated-zone lithologies. Differences were not significant within areas of either petroleum-production land or rangeland. When the land-use comparison (between petroleum-production land and rangeland) was repeated as separate tests for areas of clayey 


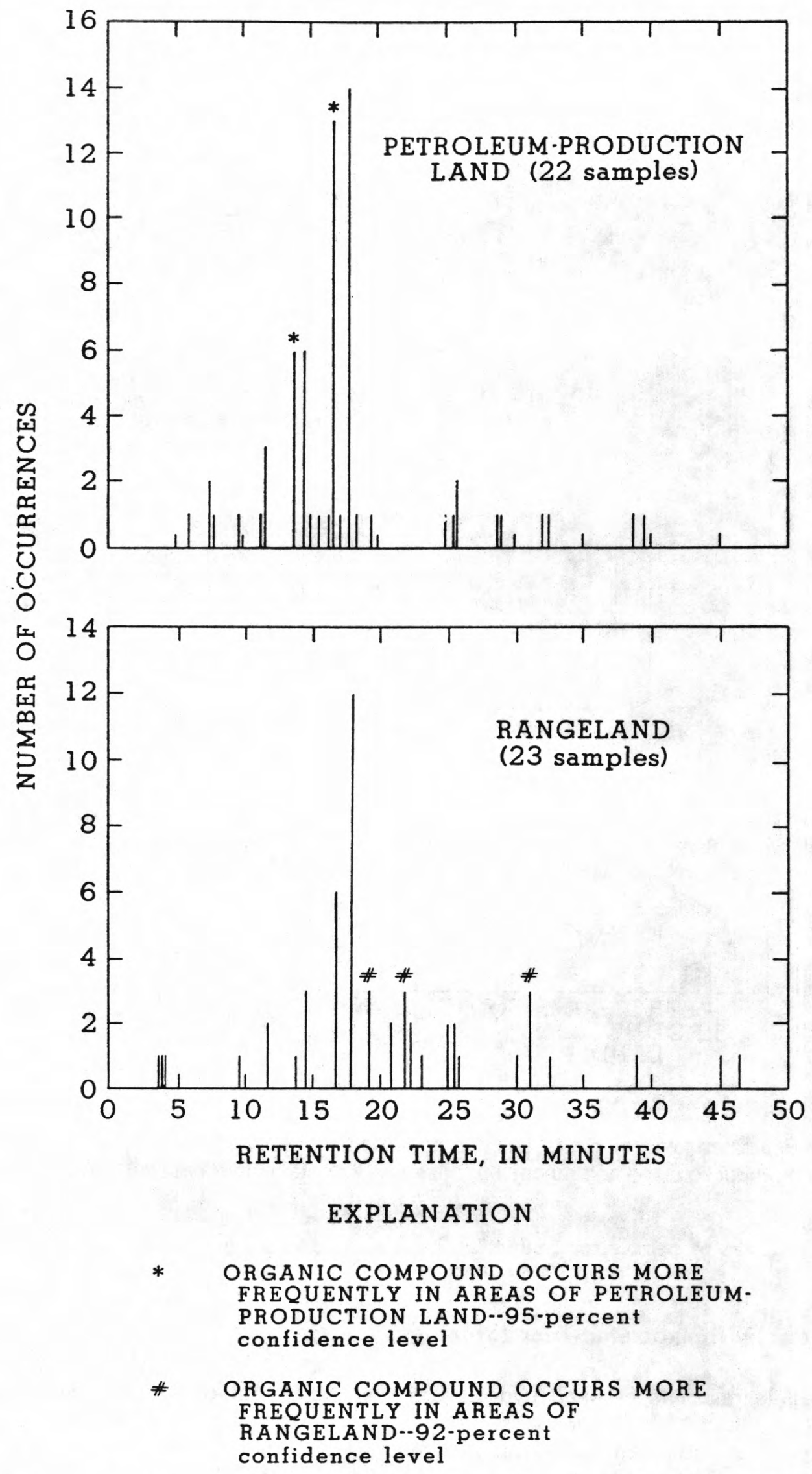

Figure 23. Frequencies of occurrence of individual organic compounds in areas of petroleum-production land and rangeland, based on gas-chromatograph retention time. 
and sandy unsaturated-zone lithologies, notably different results were produced. The test for equality was rejected at only the 14-percent confidence level for clayey lithology, but at the 92-percent confidence level for sandy lithology, with larger concentrations occurring in the areas of petroleum-production land.

The frequency of occurrence of individual peaks was compared by contingency-table testing in cases where the number of occurrences remained sufficient for valid results after dividing the data for each land-use category into unsaturated-zone lithology groups. The testing was possible for five peaks on chromatograms for petroleum-production-land samples and one peak on chromatograms for rangeland samples. A significant association was indicated for one peak on chromatograms for petroleum-production-land samples; the compound with an 11.60-minute retention time occurred more frequently in clayey unsaturated-zone lithology. When data were divided into unsaturated-zone lithology groups and then compared by land use, a significant association was indicated for one compound; in the sandy unsaturated-zone lithology, the compound with a 16.68-minute detention time occurred more frequently in areas of petroleum-production land.

Comparisons of individual peak heights, grouped according to unsaturated-zone lithology, were done using the rank-sum test; large numbers of nondetections again weaken the tests. Results indicated no significant differences within a given land-use category. However, land-use comparison tests again were repeated as separate tests for clayey and sandy unsaturated-zone lithology. Results for the compound with a 17.89-minute retention time showed only a 24-percent confidence level for rejection of equality in clayey lithology, but a 94-percent confidence level in sandy lithology, with larger concentrations in areas of petroleum-production land.

\section{DISCUSSION OF RESULTS}

Evaluation of the water-quality data and statistical comparisons from this study allowed some inferences with regard to the effects of prevailing land use on ground-water quality, the extent or scale of the effects, and the importance of unsaturated-zone lithology and type of well sampled as related to the occurrence of contaminants. Results are discussed in the following paragraphs according to land-use category. Selected results also have been presented by Helgesen and Thurman (1988) and Helgesen and Rutledge (1989). Summaries of statistical comparisons for inorganic constituents, atrazine, and hydrocarbons are shown in tables 3-5.

\section{Irrigated Cropland}

The quality of ground water beneath areas of irrigated cropland showed discernable effects of this land use. Relative to rangeland, larger concentrations of hardness, alkalinity, calcium, magnesium, potassium, fluoride, and nitrite plus nitrate (table 3 ) reflect the movement of water and solutes downward from the land surface to the saturated zone. Infiltration and percolation may be expected to be greater on tilled land than on natural rangeland. Furthermore, on irrigated cropland the natural precipitation available for infiltration is supplemented by irrigation, which uses more mineralized water pumped from the High Plains aquifer. Evapotranspiration at the land surface and in the root zone further concentrates solutes in the water that leaches through the soil.

Larger concentrations of nitrite plus nitrate beneath irrigated cropland than beneath petroleum-production land or rangeland (table 3) probably result from use of fertilizers. The relatively large fluoride concentrations beneath irrigated cropland might reflect the association of that constituent with a common phosphate-mineral component of fertilizer.

Pesticides were not detected frequently in ground water of the area, even beneath irrigated cropland, where they are commonly applied. The pesticides that were detected, especially atrazine, are relatively soluble and persistent. Although atrazine, where found in this study, was nearly always beneath areas of irrigated cropland, differences in occurrence between land-use areas were not statistically significant except when data from areas of sandy unsaturated-zone lithology were tested 
Table 3. Summary of statistical comparisons of median property values and inorganic-constituent concentrations in ground-water samples, grouped according to land-use areas, unsaturated-zone lithology, and type of well sampled

[I, areas of irrigated cropland; P, areas of petroleum-production land; R, areas of rangeland; C, clayey unsaturated-zone lithology; S, sandy unsaturated-zone lithology; SW, small-yield wells; IW, irrigation wells; --, median values or concentrations not significantly different at 95-percent confidence level]

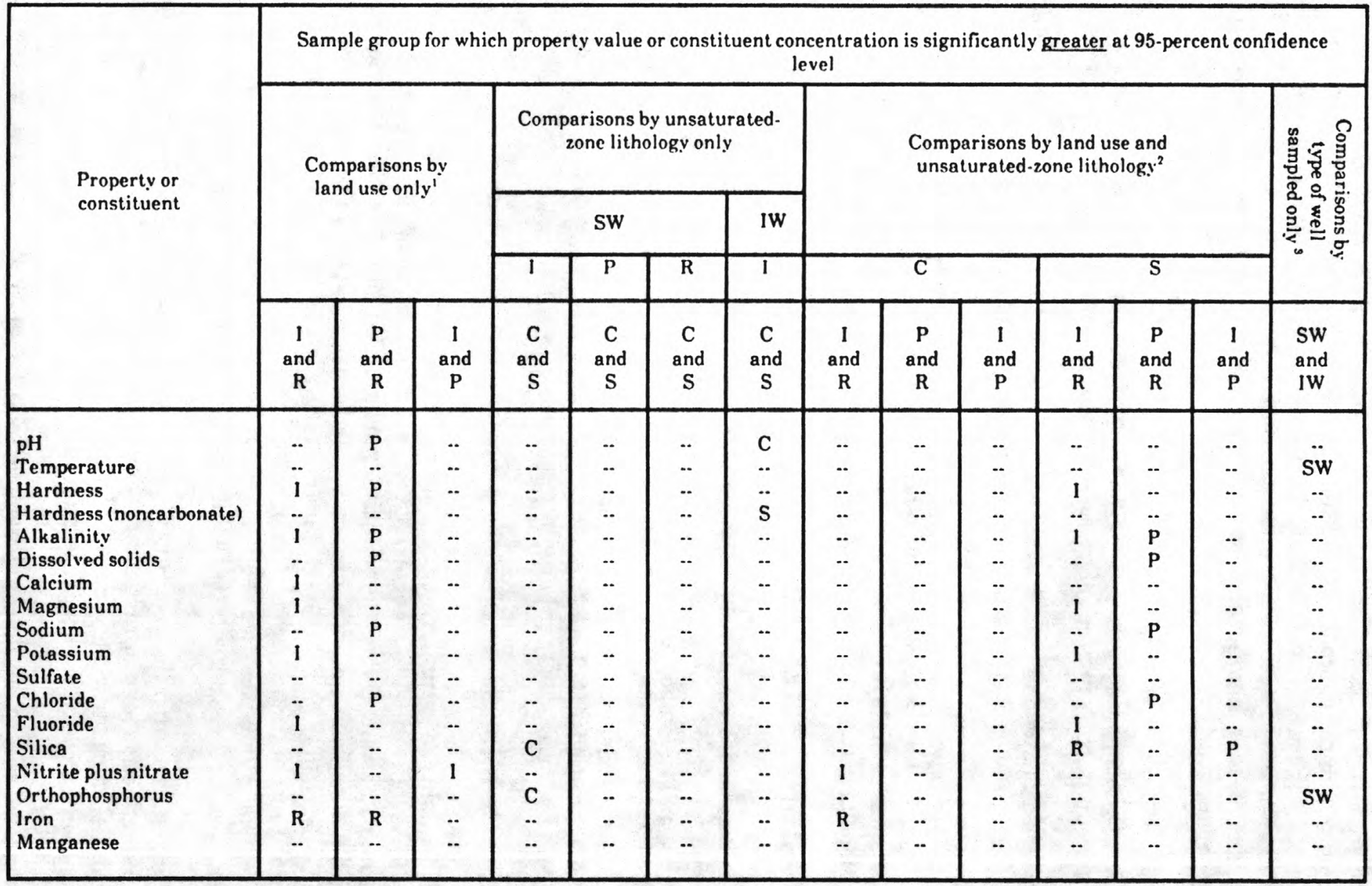

1 Small-yield wells; clayey and sandy unsaturated-zone lithologies.

2 Small-yield wells.

3 Areas of irrigated cropland; clayey and sandy unsaturated-zone lithologies. 
Table 4. Summary of statistical comparisons of atrazine detections in ground-water samples, grouped according to land-use areas, unsaturated-zone lithology, and type of well sampled

[--, frequencies of detection not significantly different at 95-percent confidence level]

Sample group for which atrazine was detected with significantly greater frequency at the 95 -percent

Comparison basis confidence level

By land use only

(Irrigated cropland and rangeland; small-yield wells; clayey and sandy unsaturated-zone lithologies)

By unsaturated-zone lithology only

(Clayey and sandy lithologies; smallyield wells; areas of irrigated cropland) ${ }^{1}$

By unsaturated-zone lithology only

(Clayey and sandy lithologies; irrigation wells; areas of irrigated cropland)

By land use and unsaturated-zone lithology

(Irrigated cropland and rangeland;

clayey unsaturated-zone lithology)

By land use and unsaturated-zone lithology

(Irrigated cropland and rangeland; sandy

Irrigated cropland

unsaturated-zone lithology)

By type of well sampled only

(Small-yield wells and irrigation wells;

areas of irrigated cropland; clayey and

sandy unsaturated-zone lithologies)

1 Statistical test for areas of rangeland not possible because of insufficient number of atrazine detections.

separately as discussed later in this section.

Concentrations of most inorganic constituents beneath areas of irrigated cropland showed no significant association with regionally delineated unsaturated-zone lithology. Concentrations of silica and orthophosphorus were significantly larger in areas of clayey as compared to sandy unsaturated-zone lithology; explanations for those differences are not evident. Although no other differences can be related directly to unsaturated-zone lithology, some significant differences between areas of irrigated cropland and rangeland are indicated if only the samples from sandy unsaturated-zone lithology in each land-use area are compared. These significant differences exist for several properties and inorganic constituents (hardness, alkalinity, magnesium, potassium, and fluoride) and for atrazine (table 4).

Conclusions regarding the effects of unsaturated-zone lithology thus appear to depend on whether the lithology groups within areas of irrigated cropland are being compared or irrigated cropland is being compared with rangeland using only sandy lithology. Reasons for these mixed results are unclear but could relate to the smaller sample size for the single land-use test and to the arbitrary nature of defining regional areas of "clayey" and "sandy" unsaturated-zone lithology. These considerations also may be factors relevant to nitrite-plus-nitrate and iron results from the clayey 
Table 5. Summary of statistical comparisons of hydrocarbon-compound detections and relative concentrations in ground-water samples, grouped according to land-use areas and unsaturated-zone lithology

[--, frequencies of detection not significantly different at 95-percent confidence level]

\begin{tabular}{|c|c|c|c|c|c|}
\hline \multirow[b]{3}{*}{ Comparison } & \multicolumn{5}{|c|}{$\begin{array}{l}\text { Sample group for which hydrocarbon-compound detection frequency } \\
\text { or concentration }{ }^{2} \text { is significantly greater at the } 95 \text {-percent confidence } \\
\text { level }\end{array}$} \\
\hline & \multirow{2}{*}{$\begin{array}{l}\text { Comparisons by } \\
\text { land use only } \\
\text { (petroleum- } \\
\text { production land } \\
\text { and rangeland) }\end{array}$} & \multicolumn{2}{|c|}{$\begin{array}{l}\text { Comparisons by } \\
\text { unsaturated-zone } \\
\text { lithology only } \\
\text { (clayey and sandy } \\
\text { lithologies) }\end{array}$} & \multicolumn{2}{|c|}{$\begin{array}{l}\text { Comparisons by land use } \\
\text { (petroleum-production } \\
\text { land and rangeland) and } \\
\text { unsaturated-zone } \\
\text { lithology }\end{array}$} \\
\hline & & $\begin{array}{l}\text { Petroleum- } \\
\text { production } \\
\text { land }\end{array}$ & $\begin{array}{l}\text { Range- } \\
\text { land }\end{array}$ & $\begin{array}{l}\text { Clayey } \\
\text { lithology }\end{array}$ & $\begin{array}{l}\text { Sandy } \\
\text { lithology }\end{array}$ \\
\hline $\begin{array}{l}\text { Total organic-compound } \\
\text { concentration }{ }^{2}\end{array}$ & - & - & - & - & - \\
\hline $\begin{array}{l}\text { Frequency of detection of } \\
\text { specific compounds }\end{array}$ & $\begin{array}{l}\text { Petroleum- } \\
\text { production land } \\
\text { ( } 2 \text { compounds) }\end{array}$ & $\begin{array}{l}\text { Clayey } \\
\text { lithology } \\
(1 \\
\text { compound })\end{array}$ & - & -. & $\begin{array}{l}\text { Petroleum- } \\
\text { production } \\
\text { land } \\
\text { (1 } \\
\text { compound) }\end{array}$ \\
\hline $\begin{array}{l}\text { Relative concentration of } \\
\text { specific compounds }\end{array}$ & $\begin{array}{l}\text { Petroleum- } \\
\text { production land } \\
\text { ( } 1 \text { compound })\end{array}$ & -. & -- & -. & -. \\
\hline
\end{tabular}

${ }^{1}$ Based on contigency-table testing.

${ }^{2}$ Based on rank-sum testing.

unsaturated-zone lithology. Nitrite-plus-nitrate concentrations were significantly larger beneath irrigated cropland than beneath rangeland based on data from clayey lithology but not sandy lithology. Iron concentrations were significantly larger beneath rangeland based on data from clayey lithology.

Despite its small-scale heterogeneity, lithology of the unsaturated zone is a factor to consider when assessing contamination. Easier downward movement of water and solutes is favored in areas of sandy unsaturated-zone lithology; the sandier material probably also makes atrazine less susceptible to sorption.

Processes of degradation and sorption probably are important in preventing most pesticides from reaching the saturated zone. At the time of the 1987 sampling, procedures were not available for analyzing degradation products of atrazine. Recently, degradation products of atrazine produced by bacterial action have been identified in samples from sites within this study area and elsewhere in Kansas (E.M. Thurman, U.S. Geological Survey, written commun., 1989) and in Nebraska (A.D. Druliner, U.S. Geological Survey, written commun., 1989). Sorption apparently is an important factor affecting the distribution of pesticides in soil profiles (particularly in organic-rich zones) within this study area (Rutledge and Helgesen, 1990) and near Topeka, Kansas (C.A. Perry, U.S. Geological 
Survey, written commun., 1989). Larger atrazine concentrations in soils tend to be associated with horizons richer in organic materials. Huang and others (1984) report that even nonorganic and nonclay fractions of a soil may be significant in atrazine adsorption.

Application of a simple mathematical model (Rutledge and Helgesen, 1989) demonstrates the importance of degradation and sorption on the transport and fate of pesticides in the unsaturated zone. The model calculates pesticide residence time and fraction of pesticide remaining in solution as a function of depth. Results of simulations using data representative of the study area indicate that several years are required for movement of relatively mobile pesticides, such as atrazine and 2,4-D, through the unsaturated zone and that the fractions remaining in solution at 20 or 30 feet below land surface (typical depths to the water table in the study area) are very small. These results are consistent with the observed infrequency of detection of nondegraded pesticides in the ground water of the study area.

Concentrations of inorganic constituents and atrazine were similar between ground water beneath irrigated fields (collected from large-yield irrigation wells) and ground water away from the fields but still within the area of irrigated cropland (collected from small-yield domestic or stock wells). This similarity indicates a predominance of regional flow over the process of recirculation of water (and solutes) within cones of depression beneath irrigated fields. Seasonal development of individual cones of depression generally do not maintain enough of a continuous diversion of water away from the regional flow pattern to establish isolated areas of anomalous water quality around irrigation wells. Regionally, although lateral solute transport is sufficiently slow to allow identification of some relations between water quality and prevailing land use in discrete areas of several square miles, it apparently is sufficiently rapid so that water quality within these discrete areas is relatively homogeneous.

Water temperatures and orthophosphorus concentrations both were significantly larger in samples from small-yield wells than from irrigation wells (table 3). The higher water temperatures probably are related to collection point; samples commonly were collected from taps within farmstead pipe systems where some warming occurred. The orthophosphorus concentrations might be attributable to animal wastes associated with the farmsteads. Lack of a significant difference between concentrations of nitrite plus nitrate in samples from small-yield and irrigation wells might reflect comparable increases of that constituent, ascribed to animal wastes at the farmsteads and fertilizers in the fields.

\section{Petroleum-Production Land}

In areas of petroleum-production land containing aggregations of former brine-disposal ponds, the inorganic quality of underlying ground water generally is affected, whereas no general effect on organic water quality is apparent. In areas of petroleum-production land, $\mathrm{pH}$ and concentrations of hardness, alkalinity, dissolved solids, sodium, and chloride significantly exceeded concentrations representative of ground water beneath rangeland (table 3 ). These differences probably reflect the percolation of brines from leaky disposal ponds downward to the aquifer. As generally was the case with irrigated cropland, significant ground-water-quality characteristics associated with petroleum-production land are recognizable in sandy unsaturated-zone lithology but not in the clayey unsaturated-zone lithology.

Comparison of ground-water quality beneath petroleum-production land with that beneath irrigated cropland indicates few statistically significant differences at the 95-percent confidence level. However, larger concentrations (at greater than 85-percent confidence level) of dissolved solids, sodium, and chloride beneath petroleum-production land (fig. 10) indicate that brine wastes might have a greater effect on inorganic ground-water quality than irrigated-cropland practices.

Organic compounds detected by GC/FID scans generally are present in ground water beneath petroleum-production land at trace concentrations comparable to those beneath undeveloped 
rangeland (total concentrations of as large as $15 \mu \mathrm{g} / \mathrm{L}$, fig. 22). The characteristics of occurrence of these organic compounds associated with these two land-use categories are not statistically different in terms of total concentration, frequency of occurrence of most specific compounds, or concentration (peak height) of most specific compounds. The few significant differences related to specific organic compounds indicate more frequent detection of relatively lighter weight compounds in the areas of petroleum-production land.

Hydrocarbons have not been introduced into the ground-water system in any way that constitutes identifiable nonpoint-source contamination. Either negligible amounts of oil-derived hydrocarbons are associated with the formerly disposed brines or, more likely, these compounds are attenuated by sorption and microbial digestion in the unsaturated and saturated zones.

\section{Rangeland}

Ground-water quality beneath most rangeland of sufficiently large extent (several square miles) probably approaches baseline (or predevelopment) conditions for the study area. However, large contiguous areas of rangeland, or any other land use, are rare; land use in much of this region is quite intermixed, so that the presence of true baseline conditions probably is rare.

Concentrations of dissolved solids and some major constituents were significantly smaller beneath areas of rangeland than beneath areas of irrigated cropland or petroleum-production land. No major-ion concentrations were significantly larger beneath rangeland than beneath other land-use areas. Increased concentrations of dissolved solids or major inorganic constituents that occurred at particular locations beneath rangeland probably can be attributed to lateral flow into the area from nearby areas of cropland or petroleum-production land.

Although pesticides are applied on some rangeland, there was only one pesticide detection in the July 1987 sampling of water from rangeland wells. That compound was atrazine, which probably accompanied lateral ground-water flow from beneath a nearby area of cropland. That sample also contained a relatively large concentration of nitrite plus nitrate, probably related to fertilizer application. In the initial reconnaissance of 1984, the herbicide 2,4-D was reported in 23 out of the 27 samples collected from areas of rangeland and irrigated cropland (Stullken and others, 1987). The expanded sampling of 1987 resulted in only 1 detection of 2,4-D (in a sample from beneath irrigated cropland) out of 82 samples, although none of the wells sampled in 1984 were resampled in 1987. This ratio ( 1 out of 82 ) does not confirm a conclusion of extensive occurrence of 2,4-D in the ground water of the study area, and the initially reported results are considered questionable.

Trace concentrations of many organic compounds are present in the ground water beneath rangeland, as inferred from results of the GC/FID scans. Concentrations were too small to allow compound identification, but their general occurrence suggests that they are naturally occurring organic compounds dissolved from the soil or aquifer materials through which the water has moved. Although the primary purpose of the GC/FID scans was to identify possible petroleum-related hydrocarbons, three specific (relatively heavier weight) compounds occurred more frequently (at the 92-percent confidence level) beneath rangeland than beneath petroleum-production land.

The effect of regionally delineated unsaturated-zone lithology was not evident in ground water beneath rangeland in terms of major inorganic constituents, atrazine, or hydrocarbons. This could be due, at least partly, to the fact that the rangeland is undeveloped and poses relatively minor contamination potential at or near the land surface. In areas of clayey unsaturated-zone lithology, relatively large concentrations of iron were detected in rangeland samples; no explanation for this condition is apparent.

\section{SUMMARY AND CONCLUSIONS}

Nonpoint-source contamination of part of the High Plains aquifer in about $5,000 \mathrm{mi}^{2}$ of 
south-central Kansas was assessed as part of the U.S. Geological Survey's Toxic Waste--Ground-Water Contamination Program. Typical of much of the Midwest, the study area is dominated by agricultural land use and also supports petroleum-production activities. Pesticides and oil-derived hydrocarbons, organic contaminants that pose potential ground-water contamination problems, were of particular interest to this study. Pesticide application is a common agricultural practice. Hydrocarbons might occur with brines produced in association with oil and formerly were disposed into unlined ponds. The study area contains permeable soils and a generally shallow water table, making ground water particularly susceptible to contamination.

The delineation and understanding of regional nonpoint-source contamination is a complex undertaking. Relating ground-water quality to overlying land use was the basic approach used. Discrete land-use areas (irrigated cropland, petroleum-production land containing former brine-disposal ponds, and undeveloped rangeland) of 3 to $10 \mathrm{mi}^{2}$ were identified. One small-yield well in each area was selected randomly for sampling and analysis on the assumption that the results would characterize ground-water quality associated with that land-use area. In addition to land use, two other factors thought to be potentially important in this regional evaluation were addressed. The effect of unsaturated-zone lithology on ground-water contamination was evaluated by categorizing each land-use area as having either a "clayey" or "sandy" unsaturated zone, as interpreted by regionalized mapping. Clay within the unsaturated zone possibly inhibits downward movement of water and chemicals. The effect of the type of well sampled was evaluated by also sampling a randomly selected irrigation well in each area of irrigated cropland. This approach allowed testing of the hypothesis that samples from irrigation wells, drawing water from directly beneath fields receiving irrigation water and agricultural chemicals, will indicate water of different quality than that from small-yield wells away from the fields.

The sampling design thus enabled comparisons based upon prevailing land use, unsaturated-zone lithology (clayey compared to sandy), and type of well sampled (irrigation compared to small yield). Although true baseline water-quality conditions probably are rare in the study area, these conditions might be represented most closely by ground water beneath the areas of undeveloped rangeland, which is a useful "control" against which to compare water quality in the developed areas. All samples collected were analyzed for major inorganic ions and other inorganic constituents commonly of interest. Samples from areas of irrigated cropland and rangeland also were analyzed for triazine and other nitrogen-containing herbicides, and chlorophenoxy-acid herbicides. Samples from areas of petroleum-production land and rangeland were analyzed for hydrocarbons using GC/FID scans.

Most data distributions for chemical properties and constituents in collected samples were non-normal and positively skewed. Statistical testing thus was based on nonparametric procedures--the two-tailed Wilcoxon-Mann-Whitney rank-sum test and contingency-table analysis. GC/FID scans revealed only trace concentrations of organic compounds that were not identifiable, although comparative analysis was done through chromatogram interpretation.

Results of this study indicate that regional water quality of the High Plains aquifer of south-central Kansas has been affected by prevailing land-use activities. The effects are principally in the form of increased concentrations of inorganic, rather than organic, constituents.

Ground water beneath areas of irrigated cropland is characterized by significantly (95-percent confidence level) larger concentrations of hardness, alkalinity, calcium, magnesium, potassium, fluoride, and nitrite plus nitrate than water beneath undeveloped rangeland. These effects are attributed to relatively large quantities of infiltration and percolation through the tilled soil and unsaturated zone, a substantial part of which consists of applied irrigation water that has been concentrated by evapotranspiration. The water dissolves minerals from the soil and subsoil and chemicals applied as fertilizer, and transports these solutes down to the aquifer. Nondegraded pesticides were detected infrequently in the aquifer. Recent identification of degradation products of atrazine at some sites warrants further study to define their extent. Atrazine itself appears to be 
present only locally in the ground water beneath areas of irrigated cropland. Concentrations generally are less than a few micrograms per liter. Other pesticides were detected even less frequently.

Ground-water quality beneath petroleum-production land containing former brine-disposal ponds exhibits significantly larger values of $\mathrm{pH}$, and concentrations of hardness, alkalinity, dissolved solids, sodium, and chloride as compared to water beneath undeveloped rangeland. These differences probably reflect the downward percolation of brines from leaky disposal ponds in those areas. Statistical differences (at greater than 85-percent confidence level) between several constituents indicate that former brine-disposal activities might have more of an effect than agricultural practices on ground-water quality in the study area, except for the increased concentrations of nitrite plus nitrate demonstrated in the areas of irrigated cropland. Nonpoint-source contamination by oil-derived hydrocarbons was not discernible in areas of petroleum-production land. Occurrences of trace-organic compounds were similar between areas of petroleum-production land and undeveloped rangeland, which indicates that most or all of these organic compounds are naturally occurring and probably dissolved from soil or aquifer materials.

Mixed results concerning the effects of unsaturated-zone lithology probably relate to small sample size when testing within a single land-use area and to the arbitrary nature of defining regional "clayey" and "sandy" lithologies. The unsaturated zone is lithologically heterogeneous and contains substantial clay that inhibits the downward movement of water and solutes. Movement of percolating water through the unsaturated zone might require several months to several years to reach the water table. Atrazine in the study area is believed to be concentrated mostly in the soil zone, and degradation and sorption probably account for infrequent detection of atrazine in the ground water.

Within the aquifer, the rate of regional lateral flow and solute transport is sufficiently slow so that the ground-water quality reflects, to some extent, prevailing overlying land use in discrete areas of several square miles. Regional flow is sufficiently rapid, however, so that the type of well sampled is not important in regional characterization of the water quality beneath areas of irrigated cropland; the seasonal pumping of irrigation wells does not appear to divert regional flow enough to cause discernible local anomalies of more mineralized ground water.

\section{REFERENCES}

Bevans, H.E., 1989, Water resources of Sedgwick County, Kansas: U.S. Geological Survey Water-Resources Investigations Report 88-4225, $119 \mathrm{p}$.

Burrton Task Force, 1984, Report of the Burrton Task Force to the Chief Engineer-Director of the Kansas State Board of Agriculture, Division of Water Resources, concerning the Proposed Burrton Intensive Ground-Water Use Control Area: Topeka, Kansas Water Agencies, 103 p.

Chen, H.H., and Druliner, A.D., 1987, Nonpoint-source agricultural chemicals in ground water in Nebraska--Preliminary results for six areas of the High Plains aquifer: U.S. Geological Survey Water-Resources Investigations Report 86-4338, 68 p.

Cheng, H.H., and Koskinen, W.C., 1986, Processes and factors affecting transport of pesticides to ground water, in Garner, W.Y., Honeycutt, R.C., and Nigg, H.N. eds., Evaluation of pesticides in ground water: Washington, D.C., American Chemical Society, p. 3-13.

Cobb, P.M., Colarullo, S.J., and Heidari, Manoucher, 1983, A ground-water flow model for the Great Bend aquifer, south-central Kansas: Kansas Geological Survey Open-File Report 83-20, 220 p. 
Druliner, A.D., 1989, Overview of the relations of nonpoint-source agricultural chemical contamination to local hydrogeologic, soil, land-use, and hydrochemical characteristics of the High Plains aquifer of Nebraska, in Mallard, G.E., and Ragone, S.E., eds., U.S. Geological Survey Toxic Substances Hydrology Program--Proceedings of the Technical Meeting, Phoenix, Arizona, September 26-30, 1988: U.S. Geological Survey Water-Resources Investigations Report $88-4220$, p. $411-435$.

Fader, S.W., and Stullken, L.E., 1978, Geohydrology of the Great Bend Prairie, south-central Kansas: Kansas Geological Survey Irrigation Series 4, 19 p.

Feltz, H.R., Lewis, J.A, and Cardinali, F.L., 1986, Application of the gas chromatographic/flame ionization detector analysis, in Ragone, S.E., ed., U.S. Geological Survey Program on Toxic Waste--Ground-Water Contamination--Proceedings of the Second Technical Meeting, Cape Cod, Massachusetts, October 21-25, 1985: U.S. Geological Survey Open-File Report 86-481, p. F11-F15.

Frye, J.C., and Brazil, J.J., 1943, Ground water in the oil-field areas of Ellis and Russell Counties, Kansas: Kansas Geological Survey Bulletin 50, 104 p.

Hathaway, L.R., Galle, O.K., Waugh, T.C., and Dickey, H.P., 1978, Chemical quality of irrigation waters in Ford County and the Great Bend Prairie of Kansas: Kansas Geological Survey Chemical Quality Series 7, 41 p.

Hathaway, L.R., Waugh, T.C., Galle, O.K, and Dickey, H.P., 1981, Chemical quality of irrigation water in the Equus beds area, south-central Kansas: Kansas Geological Survey Chemical Quality Series 10,45 p.

Helgesen, J.O., and Rutledge, A.T., 1989, Relations between land use and water quality in the High Plains aquifer of south-central Kansas, in Mallard, G.E., and Ragone, S.E., eds., U.S. Geological Survey Toxic Substances Hydrology Program--Proceedings of the Technical Meeting, Phoenix, Arizona, September 26-30, 1988: U.S. Geological Survey Water-Resources Investigations Report 88-4220, p. 437-443.

Helgesen, J.O., and Thurman, E.M., 1988, Trace organic compounds in ground water in south-central Kansas as inferred from gas chromatography with flame-ionization detection: American Chemical Society, Division of Environmental Chemistry, v. 28, no. 2, p. 9-12.

Helsel, D.R., and Ragone, S.E., 1984, Evaluation of regional ground-water quality in relation to land use--U.S. Geological Survey Toxic Waste--Ground-Water Contamination Program: U.S. Geological Survey Water-Resources Investigations Report 84-4217, 33 p.

Huang, P.M., Grover, R., and McKercher, R.B., 1984, Components and particle size fractions involved in atrazine adsorption by soils, in Saltzman, S. and Yaron, B., eds., Pesticides in soil: New York, Van Nostrand Reinhold Co., p. 33-37.

Huntzinger, T.L., and Stullken, L.E., 1988, An experiment in representative ground-water sampling for water-quality analysis: U.S. Geological Survey Water-Resources Investigations Report $88-4178,12 \mathrm{p}$.

Iman, R.L., and Conover, W.J., 1983, A modern approach to statistics: New York, John Wiley and Sons, $497 \mathrm{p}$.

Kansas Department of Health and Environment, 1982, Groundwater quality management plan for the State of Kansas: Kansas Department of Health and Environment Bulletin 3-4, 76 p. 
Koelliker, J.K, Steiken, J.M., Yearout, R.D., Heiman, A.T., and Grosh, D.L., 1987, Identification of factors affecting farmstead well water quality: Manhattan, Kansas Water Resources Research Institute Report No. G1226-02, 50 p.

Leonard, A.R., and Berry, D.W., 1961, Geology and ground-water resources of southern Ellis County and parts of Trego and Rush Counties: Kansas Geological Survey Bulletin 149, 156 p.

Luckey, R.R., Gutentag, E.D., Heimes, F.J., and Weeks, J.B., 1986, Digital simulation of ground-water flow in the High Plains aquifer in parts of Colorado, Kansas, Nebraska, New Mexico, Oklahoma, South Dakota, Texas, and Wyoming: U.S. Geological Survey Professional Paper $1400-\mathrm{D}, 57 \mathrm{p}$.

Nilson, E.B., and Johnson, M.E., 1980, Kansas 1978 pesticide usage: Manhattan, Kansas Crop and Livestock Reporting Service and Kansas State University Cooperative Extension Service, 36 p.

Perry, C.A., 1990, Source, extent, and degradation of herbicides in a shallow aquifer near Hesston, Kansas: U.S. Geological Survey Water-Resources Investigations Report 90-4019, 24 p.

Perry, C.A., and Anderson, M.R., 1991, Statistical comparison of selected chemical constituents in water from chemigation and conventional irrigation wells in Kansas, 1987: U.S. Geological Survey Water-Resources Investigations Report 91-4049, 1 sheet.

Perry, C.A., Robbins, F.V., and Barnes, P.L., 1988, Factors affecting leaching in agricultural areas and an assessment of agricultural chemicals in the ground water of Kansas: U.S. Geological Survey Water-Resources Investigations Report 88-4104, 55 p.

Power, J., 1982, A plan for protection of Kansas ground-water resources from pollution, in Nielson, D.M., ed., Sixth National Groundwater Quality Symposium: Worthington, Ohio, National Water Well Association, 318 p.

Rutledge, A.T., and Helgesen, J.O., 1989, Use of a simplified transport model for pesticides in the unsaturated zone, in Mallard, G.E., and Ragone, S.E., eds., U.S. Geological Survey Toxic Substances Hydrology Program--Proceedings of the Technical Meeting, Phoenix, Arizona, September 26-30, 1988: U.S. Geological Survey Water-Resources Investigations Report 88-4220, p. 523-530.

1990, Characterization of ground-water flow and chemical transport beneath two irrigated fields in south-central Kansas, 1988: U.S. Geological Survey Water-Resources Investigations Report 90-4065, $37 \mathrm{p}$.

Severn, D.J., 1987, Pesticides and the ground water connection, in Pesticides and groundwater-A health concern for the Midwest--Proceedings of Conference, St. Paul, Minnesota, October 16-17, 1986: Navarre, Minnesota, Freshwater Foundation, p. 29-44.

Skougstad, M.W., and others, eds., 1979, Methods for determination of inorganic substances in water and fluvial sediments: U.S. Geological Survey Techniques of Water-Resources Investigations, Book 5, Chapter A1, 626 p.

Sophocleous, M.A, 1983, Water-quality modeling of the Equus-beds aquifer in south-central Kansas: Kansas Geological Survey Open-File Report 83-1, 75 p. 
Sophocleous, M.A., and Perry, C.A., 1987, Measuring and computing natural ground-water recharge at sites in south-central Kansas: U.S. Geological Survey Water-Resources Investigations Report 87-4097, 48 p.

Spinazola, J.M., Gillespie, J.B., and Hart, R.J., 1985, Ground-water flow and solute transport in the Equus beds area, south-central Kansas, 1940-79: U.S. Geological Survey Water-Resources Investigations Report 85-4336, 68 p.

Spruill, T.B., 1983, Statistical summaries of selected chemical constituents in Kansas ground-water supplies, 1976-81: U.S. Geological Survey Open-File Report 83-263, 29 p.

Steeples, D.W., and Buchanan, R.C., 1983, Kansas geomaps: Kansas Geological Survey Educational Series 4, $30 \mathrm{p}$.

Stramel, G.J., 1956, Progress report on the ground-water hydrology of the Equus beds area, Kansas: Kansas Geological Survey Bulletin 119, part 1, 59 p.

1967, Progress report on the ground-water hydrology of the Equus beds area, Kansas, 1966: Kansas Geological Survey Bulletin 187, part 2, 25 p.

Stullken, L.E., and Fader, S.W., 1976, Hydrogeologic data from the Great Bend Prairie, south-central Kansas: Kansas Geological Survey Basic Data Series, Ground-Water Release 5, 50 p.

Stullken, L.E., Stamer, J.K, and Carr, J.E., 1987, Reconnaissance of water quality in the High Plains aquifer beneath agricultural lands, south-central Kansas: U.S. Geological Survey Water-Resources Investigations Report 87-4003, 25 p.

Stullken, L.E., Watts, K.R., and Lindgren, R.J., 1985, Geohydrology of the High Plains aquifer, western Kansas: U.S. Geological Survey Water-Resources Investigations Report 85-4198, 86 p.

U.S. Geological Survey, 1979a, Land use and land cover, 1974, Great Bend, Kansas: U.S. Geological Survey Map L-21, scale 1:250,000, 1 sheet.

1979b, Land use and land cover, 1974, Hutchinson, Kansas: U.S. Geological Survey Map L-23, scale $1: 250,000,1$ sheet.

1979c, Land use and land cover, 1974, Pratt, Kansas: U.S. Geological Survey Map L-28, scale $1: 250,000,1$ sheet.

1979d, Land use and land cover, 1974, Wichita, Kansas: U.S. Geological Survey Map L-30, scale $1: 250,000,1$ sheet.

Williams, D.L., and Barker, B.L., no date, Kansas land-use patterns, summer 1973 (map): Lawrence, Space Technology Laboratories, University of Kansas, scale 1:1,000,000, 1 sheet.

Williams, C.C., and Lohman, S.W., 1949, Geology and ground-water resources of a part of south-central Kansas, with specific reference to the Wichita municipal water supply: Kansas Geological Survey Bulletin 79, 455 p. 
Table 6. Results of water-quality analyses, grouped according to land-use areas, unsaturated-zone lithology, and type of well sampled

[Analyses by U.S. Geological Survey. Units of measurement: $\mu \mathrm{S} / \mathrm{cm}$, microsiemens per centimeter at 25 degrees Celsius; deg C, degrees Celsius; $\mathrm{mg} / \mathrm{L}$, milligrams per liter; $\mu \mathrm{g} / \mathrm{L}$, micrograms per liter. <, less than; --, no analysis]

\begin{tabular}{|c|c|c|c|c|c|c|c|c|c|c|}
\hline $\begin{array}{l}\text { Well number } \\
\text { (latitude, longitude } \\
\text { sequence number) }\end{array}$ & County & $\begin{array}{l}\text { Date of collection } \\
\text { (month-day-year) }\end{array}$ & $\begin{array}{c}\text { Specific } \\
\text { conductance } \\
(\mu \mathrm{S} / \mathrm{cm})\end{array}$ & $\begin{array}{c}\mathrm{pH} \\
\text { (standard units) }\end{array}$ & $\begin{array}{l}\text { Tempera ture, } \\
\text { water (deg C) }\end{array}$ & $\begin{array}{l}\text { Hardness, lotal } \\
\left(\mathrm{mg} / \mathrm{Las} \mathrm{CaCO}_{3}\right)\end{array}$ & $\begin{array}{c}\text { Hardnes, } \\
\text { noncartonate } \\
\left(\mathrm{mg} / \mathrm{L} \text { as } \mathrm{CaCO}_{3}\right)\end{array}$ & $\begin{array}{c}\text { Alkalinity, } \\
\left(\mathrm{mg} / \mathrm{L} \text { aв } \mathrm{CaCO}_{3}\right)\end{array}$ & $\begin{array}{l}\text { Solids, sum of } \\
\text { constituents, } \\
\text { dissolved } \\
(\mathrm{mg} / \mathrm{L})\end{array}$ & $\begin{array}{l}\text { Calcium, } \\
\text { dissolved } \\
\text { (mg/L as } \mathrm{Ca})\end{array}$ \\
\hline
\end{tabular}

CLAYEY LITHOLOGY

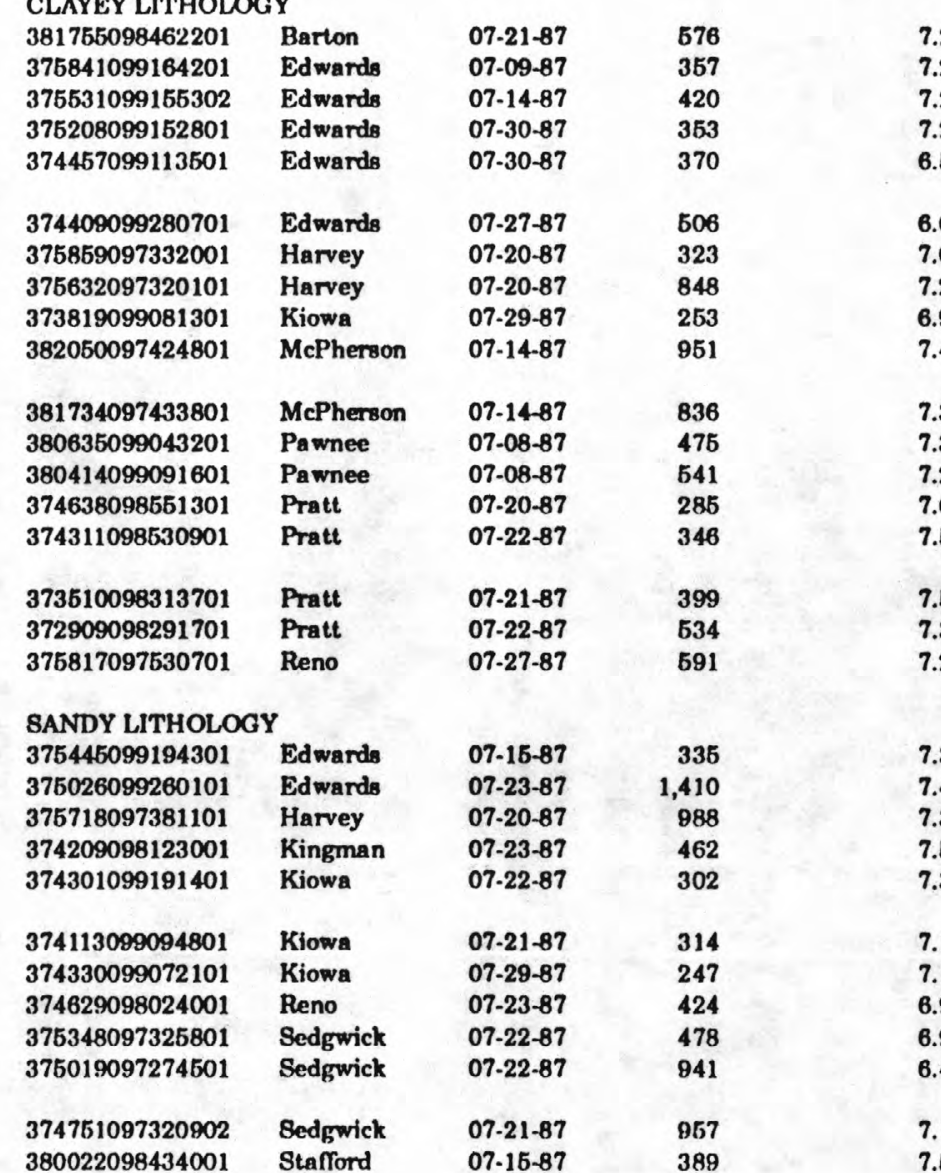

Areas of irrigated cropland (small-yield wells)

\begin{tabular}{|c|c|c|}
\hline 7.2 & 16.0 & 220 \\
\hline 7.2 & 16.0 & 180 \\
\hline 7.2 & 15.0 & 180 \\
\hline 7.2 & 14.5 & 150 \\
\hline 6.5 & 15.0 & 130 \\
\hline 6.6 & 17.0 & 200 \\
\hline 7.0 & 16.0 & 110 \\
\hline 7.2 & 16.5 & 250 \\
\hline 6.9 & 15.0 & 120 \\
\hline 7.4 & 16.0 & 430 \\
\hline 7.3 & 16.0 & 350 \\
\hline 7.3 & 15.5 & 190 \\
\hline 7.2 & 15.0 & 210 \\
\hline 7.6 & 15.5 & 120 \\
\hline 7.5 & 18.0 & 140 \\
\hline 7.5 & 16.0 & 180 \\
\hline 7.3 & 15.5 & 260 \\
\hline 7.2 & 16.0 & 250 \\
\hline 7.3 & 17.0 & 150 \\
\hline 7.4 & 15.5 & 520 \\
\hline 7.3 & 16.0 & 320 \\
\hline 7.5 & 16.0 & 170 \\
\hline 7.3 & 15.0 & 210 \\
\hline 7.1 & 15.5 & 130 \\
\hline 7.1 & 16.0 & 110 \\
\hline 6.9 & 17.0 & 150 \\
\hline 6.9 & 16.5 & 160 \\
\hline 6.4 & 16.5 & 230 \\
\hline 7.1 & 16.0 & 320 \\
\hline 7.5 & 15.0 & 150 \\
\hline
\end{tabular}

\begin{tabular}{|c|c|c|c|}
\hline 16 & 200 & 331 & 72 \\
\hline 25 & 160 & 259 & 60 \\
\hline 13 & 170 & 258 & 60 \\
\hline 42 & 110 & 228 & 50 \\
\hline 38 & 96 & 220 & 46 \\
\hline 160 & 40 & 348 & 61 \\
\hline 0 & 140 & 208 & 34 \\
\hline 0 & 270 & 556 & 79 \\
\hline 34 & 86 & 192 & 41 \\
\hline 130 & 300 & 568 & 150 \\
\hline 70 & 280 & 486 & 120 \\
\hline 0 & 200 & 295 & 64 \\
\hline 0 & 220 & 333 & 71 \\
\hline 17 & 100 & 181 & 42 \\
\hline 40 & 97 & 203 & 49 \\
\hline 32 & 160 & 237 & 65 \\
\hline 35 & 220 & 323 & 92 \\
\hline 1 & 250 & 404 & 87 \\
\hline 23 & 130 & 209 & 49 \\
\hline 340 & 180 & 934 & 160 \\
\hline 58 & 270 & 614 & 100 \\
\hline 34 & 140 & 290 & 60 \\
\hline 88 & 130 & 284 & 74 \\
\hline 21 & 110 & 209 & 47 \\
\hline 10 & 89 & 159 & 37 \\
\hline 26 & 120 & 264 & 48 \\
\hline 3 & 150 & 277 & 49 \\
\hline 120 & 110 & 535 & 71 \\
\hline 38 & 290 & 558 & 85 \\
\hline 0 & 160 & 239 & 52 \\
\hline
\end{tabular}


Table 6. Results of water-quality analyses, grouped according to land-use areas, unsaturated-zone lithology, and type of well sampled--Continued

\begin{tabular}{|c|c|c|c|c|c|c|c|c|c|c|}
\hline $\begin{array}{l}\text { Well number } \\
\text { (latitude, longitude, } \\
\text { sequenoc number) }\end{array}$ & County & $\begin{array}{c}\text { Magnesium } \\
\text { dissolved } \\
\text { (mg/L as } \mathrm{Mg})\end{array}$ & $\begin{array}{c}\text { Sodium, } \\
\text { dissolved } \\
\text { (mg/L as } \mathrm{Na})\end{array}$ & $\begin{array}{l}\text { Potassium, } \\
\text { dissolved } \\
\text { (mg/la as K) }\end{array}$ & $\begin{array}{c}\text { Sulfate, } \\
\text { dissolved } \\
\left(\mathrm{mg} / \mathrm{L} \text { as } \mathrm{SO}_{4}\right)\end{array}$ & $\begin{array}{l}\text { Chloride, } \\
\text { dissolved } \\
\text { (mg/L as Cl) }\end{array}$ & $\begin{array}{l}\text { Fluoride, } \\
\text { dissolved } \\
\text { (mg/L as F) }\end{array}$ & $\begin{array}{c}\text { Silica, } \\
\text { dissolved } \\
\left(\mathrm{mg} / \mathrm{h} \text { as } \mathrm{SiO}_{2}\right)\end{array}$ & $\begin{array}{l}\text { Nitrogen, } \\
\mathrm{NO}_{2}+\mathrm{NO}_{3} \text {, } \\
\text { dissolved } \\
\text { (mg/l as N) }\end{array}$ & $\begin{array}{c}\text { Phos phorus, } \\
\text { ortho, } \\
\text { dissolved } \\
\text { (mg/L as } \mathrm{P} \text { ) }\end{array}$ \\
\hline
\end{tabular}

Areas of irrigated cropland (small-yield wells)--Continued

CLAYEY LITHOLOGY

381755098462201 Barton

375841099164201 Edwards

375531099155302 Edwards

375208099152801 EdwardB

$374457099113501 \quad$ Edwands

37409099280701

375859097332001

375632097320101

373819099081301

\section{Edwards}

Harvey

Harvey

382050097424801

Kiowa

McPherson

381734097433801

380635099043201

380414099091601

374638098551301

McPherson

Pawnee

37431109853090

Pawnee

Pratt

373510098313701

372909098291701

Pratt

375817097530\%1

Reno

SANDY LITHOLOGY

375445099194301 Edwards

375029099260101

Edwards

375718097381101

374209098123001 Kingman

374301099191401

Kiowa

374113099094801

\section{Kiowa}

37433009907210

37462909802400

375348097325801

Kiowa

Reno

375019097274501

Sedgwick

374751097320902

380022098434001

\section{Bedgwick}

Stafford

$\begin{array}{cc}6.9 & 11 \\ 30 & 90 \\ 18 & 96 \\ 5.1 & 24 \\ 6.9 & 35 \\ & \\ 4.1 & 10 \\ 3.8 & 5 \\ 7.3 & 22 \\ 8.2 & 32 \\ 14 & 84 \\ 21 & \\ 5.3 & 82 \\ & 22\end{array}$

30
17
16
11
12
19
32
100
9.3
32

$\begin{array}{ll}22 & 38 \\ 16 & 11 \\ 20 & 6.2 \\ 24 & 8.2 \\ 21 & 11 \\ 88 & 36 \\ 14 & 11 \\ 85 & 77 \\ 11 & 5.1 \\ 26 & 79\end{array}$

0.5
.5
.5
.3
.3
.1
.5
.5
.3
.2

$\begin{array}{llr}19 & 3.7 & 0.03 \\ 22 & 6.6 & .03 \\ 22 & 5.2 & .04 \\ 27 & 8.1 & .08 \\ 28 & 8.3 & .12\end{array}$

.03
.03
.04
.08
.12

18

$<.10$

$<.10$
8.6

12

.05
.12
.05
.13
.06

65

$\begin{array}{rr}24 & 4 \\ 440 & 45 \\ 110 & 110 \\ 15 & 17 \\ 30 & 35\end{array}$

2

11

87

$\begin{array}{ll}3.2 & .02 \\ 7.8 & .01 \\ <.10 & .02 \\ 14 & .07 \\ 1.9 & .01 \\ & \\ 8.3 & .09 \\ 5.1 & .03 \\ 12 & .08 \\ 7.2 & .03 \\ 10 & .02 \\ & \\ 8.8 & .11 \\ 4.3 & .03\end{array}$


Table 6. Results of water-quality analyses, grouped according to land-use areas, unsaturated-zone lithology, and type of well sampled--Continued

\begin{tabular}{|c|c|c|c|c|c|c|c|c|c|c|}
\hline $\begin{array}{l}\text { Well number } \\
\text { (latitude, longitude, } \\
\text { sequence number) }\end{array}$ & County & $\begin{array}{c}\text { Iron, } \\
\text { dissolved } \\
(\mu \mathrm{g} / \mathrm{L} \text { as } \mathrm{Fe})\end{array}$ & $\begin{array}{c}\text { Manganese, } \\
\text { dissolved } \\
(\mu \mathrm{g} / \mathrm{L} \text { as } \mathrm{Mn})\end{array}$ & $\begin{array}{l}\text { Alachlor, } \\
\text { total }(\mu g / L)\end{array}$ & $\begin{array}{l}\text { Ametryne, } \\
\text { total }(\mu g / L)\end{array}$ & $\begin{array}{l}\text { Atrazine, } \\
\text { total }(\mu \mp / L)\end{array}$ & $\begin{array}{l}\text { Cyanazine, } \\
\text { total }(\mu \mathrm{g} / \mathrm{L})\end{array}$ & $\begin{array}{c}\text { Metolachlor, } \\
\text { total }(\mu \mathrm{g} / \mathrm{L})\end{array}$ & $\begin{array}{l}\text { Metribusin, } \\
\text { total (ug/L) }\end{array}$ & $\begin{array}{l}\text { Prometone, } \\
\text { total, }(\mu q / \mathrm{L})\end{array}$ \\
\hline
\end{tabular}

Areas of irrigated cropland (small-yield wells)--Continued

CLAYEY LITHOLOGY

38175509846220

375841099164201 Barton

375531099155302 Ed

375208099152801

374457099113501 Edwards

374409099280701 Edwards

375859097332001

375632097320101

37381909908130

382050097424801

381734097433801

380635099043201

380414099091601

37463809855130

374311098530901

373510098313701

372909098291701

375817097530701

Harvey

Harvey

McPherson

McPherson

Pawnee

Pawnee

Pratl

Pratt

Pratt

Prath

SANDY LITHOLOGY

375445099194301

375029099260101

375718097381101

Edwards

374209098123001

374301099191401

Edwards

Harvey

Kingma

374113099094801

374330099072101

Kiowa

$<3$
$<3$
$<3$
10
20
7
7
870
420
$<3$
6
5
5
4
$<3$
$<3$
10
$<3$
$<3$
5

Kiowa

Kiowa

3746290980240

375019097274501

Reno

Sedgwick

374751097320502

Sedgwick

9
2
$<1$
5
3
21
270
460
1
1
$<1$
1
$<1$
$<1$
3
$<1$
$<1$
1

\section{$<0.10$}

$<.10$

$<.10$

$<.10$

$<.10$
$<.10$
$<10$

$<.10$

$<.10$

$<.10$

$<.10$

$<.10$

$<.10$

$<.10$

$<.10$

$<.10$

$<.10$

$<.10$

$<.10$

$<.10$
$<.10$
$<.10$

$<.10$

$<.10$

$<.10$

$<.10$

$<.10$

$<.10$

$<.10$

$<10$

\section{$<0.10$}

$<.10$

$<.10$

$<.10$
$<.10$

$<.10$

$<.10$

$<.10$

$<.10$

$<.10$

$<.10$

$<.10$

$<.10$

$<.10$

$<.10$

$<.10$

$<.10$

$<.10$

$<.10$

$<.10$

$<.10$

$<.10$
$<.10$

$<.10$

$<.10$

$<.10$

$<.10$
$<.10$

$<.10$

$<.10$

\section{$<0.10$}

$<.10$

$<.10$

$<.10$
3.8

$<.10$

$<.10$

$<.10$

$<.10$

$<.10$

$<.10$

$<.10$

$<.10$

$<.10$

$<.10$

$<.10$

$<.10$

$<.10$

$<.10$

$<.10$

$<.10$

$<.10$

$<.10$

$<.10$

$<.10$

$<.10$

$<.10$

$<.10$
$<.10$

$<0.10$
$<.10$
$<.10$
$<.10$
$<.10$

$<.10$
$<.10$
$<.10$
$<.10$
$<.10$
$<.10$
$<.10$
$<.10$
$<.10$
$<.10$

$<.10$
$<.10$
$<.10$

$<.10$

$<.10$

$<.10$

$<.10$

$<.10$

$<.10$

$<.10$

.30

.90

$<.10$

\begin{tabular}{|c|c|c|}
\hline$<0.1$ & $<0.1$ & $<0.1$ \\
\hline$<.1$ & $<.1$ & $<.1$ \\
\hline$<.1$ & $<.1$ & $<.1$ \\
\hline$<.1$ & $<.1$ & $<.1$ \\
\hline$<.1$ & $<.1$ & $<.1$ \\
\hline$<.1$ & $<.1$ & $<.1$ \\
\hline$<.1$ & $<.1$ & $<.1$ \\
\hline$<.1$ & $<.1$ & $<.1$ \\
\hline$<.1$ & $<.1$ & $<.1$ \\
\hline$<.1$ & $<.1$ & $<.1$ \\
\hline$<.1$ & $<.1$ & $<.1$ \\
\hline$<.1$ & $<.1$ & $<.1$ \\
\hline$<.1$ & $<.1$ & $<.1$ \\
\hline$<.1$ & $<.1$ & $<.1$ \\
\hline$<.1$ & $<.1$ & $<.1$ \\
\hline$<.1$ & $<.1$ & $<.1$ \\
\hline$<.1$ & $<.1$ & $<.1$ \\
\hline
\end{tabular}

0.1

$<.1$

<.1

$<.1$

$<.1$

$<.1$

$<.1$

$<.1$

$<.1$

$<.1$

$<.1$

$<.1$

$<.1$

$<.1$

$<.1$

$<.1$

$<.1$

$<.1$

$<.1$ 
Table 6. Results of water-quality analyses, grouped according to land-use areas, unsaturated-zone lithology, and type of well sampled--Continued

Well number

(latitude, longitude

(a)

County

Prometryne, Propazine,

Silvex,

Simazine,

Simetryne,

Trifluralin,

total $(\mu \mathrm{g} / \mathrm{L})$

2,4-D,

total $(\mu \mathrm{g} / \mathrm{L})$

2,4-DP,

total ( $\mu g / \mathrm{L})$

$2,4,5-\mathrm{T}$

Areas of irrigated cropland (small-yield wells).-Continued

CLAYEY LITHOLOGY

381755098462201

$375841099164201 \quad$ Edward

375531099155302 Edwards

375208099152801 Edwards

374457099113501 Edwards

374409099280701

375859097332001

375632097320101

373819099081301

Edwards

382050097424801

Harvey

Harvey

Kiowa

McPherson

\section{$<0.1$}

$<.1$

$<.1$

$<1$

$<.1$

$<.1$

382050097424801

381734097433801

380635099043201

380414099091601

374311098530901

McPherson

Pawnee

Pawnee

Pratt

373510098313701

372909098291701

Pratt

Pratt

Reno

\section{SANDY LITHOLOGY}

375445099194301

Edwards

Edwards

Harvey

Kingman

Kjowa

374113099094801

374330099072101

Kiowa

Kiowa

77534007325801

Reno

375019097274501

Sedgwick
Sedgwick

Sedgwick

Stafford

380022098434001

$\begin{array}{lll}<0.10 & <0.01 & <0.10 \\ <.10 & <.01 & <.10 \\ <.10 & <.01 & <.10 \\ <.10 & <.01 & <.10 \\ <.10 & <.01 & <.10 \\ & <.01 & \\ .10 & <.01 & <.10 \\ <.10 & <.01 & <.10 \\ <.10 & <.01 & <.10 \\ <.10 & <.01 & <.10 \\ <.10 & <.01 & <.10 \\ & & \\ <.10 & <.01 & <.10 \\ <.10 & <.01 & <.10 \\ <.10 & -. & <.10 \\ <.10 & <.01 & <.10 \\ <.10 & <.01 & <.10 \\ <.10 & & <.10 \\ <.10 & <.01 & <.10 \\ <.10 & <.01 & <.10\end{array}$

$<0.1$
$<.1$
$<.1$
$<.1$
$<.1$
$<.1$
$<.1$
$<.1$
$<.1$
$<.1$
$<.1$
$<.1$
$<.1$
$<.1$
$<.1$
$<.1$
$<.1$
$<.1$

\section{$<0.10$}

$<.10$
$<.10$

$<10$

$<.10$

$<.10$

$<.10$

$<.10$

$<10$

$<.10$

$<.10$

$<.10$

$<.10$

.10

$<.10$

$<.10$

$<.10$

$<.10$

$<.01 \quad<.10$

$<.10$

$<.10$

$<.10$

$<.10$

$<.01$

$<.01$

$<.01$

$<.10$

$<.10$

$<10$

$<.10$

$<.10$

$<.10$

$<.10$

$<10$

$<.10$

$<.10$

$<.10$

$<.01$

$<.01$

$<01$

$<.01$

$<.01$

$<.01$

$<.10$

$<.10$

$<.10$

$<.10$

$<.10$

$<.1$

$<.1$

$<.1$

$<.1$

$<.1$

$<.1$

$<.1$

$<.1$

$<.1$

$<.1$

$<.1$

$<.10$

.40
$<.10$

$<.10$

$<.10$

$<.10$

$<.10$

$<.10$

$<.10$

$<.10$

$<.10$

10

$\begin{array}{lll}<0.01 & <.01 & <.01 \\ <.01 & <.01 & <.01 \\ <.01 & <.01 & <.01 \\ <.01 & <.01 & <.01 \\ <.01 & <.01 & <.01 \\ <.01 & <.01 & <.01 \\ <.01 & <.01 & <.01 \\ <.01 & <.01 & <.01 \\ <.01 & <.01 & <.01 \\ <.01 & <.01 & <.01 \\ <.01 & & \\ & <.01 & <.01 \\ .01 & <.01 & <.01 \\ <.01 & - & - \\ .01 & <.01 & <.01 \\ <.01 & <.01 & <.01 \\ <.01 & & <.01 \\ <.01 & <.01 & <.01 \\ <.01 & <.01 & <.01 \\ <.01 & <.01 & <.01\end{array}$

.01

01

$<.01$

.01

$<.01$

$<.01$

01

$<.01$

$<.01$

$<.01$

$<.01$

$<.01$

$<.01$

$<.01$

$<.01$

$<.01$

$<.01$

$<.01$

$<.01$

$<.01$

$<.01$

$<.01$

$<.01 \quad<.01$

$<.01 \quad<.01$

$<.01<<01$

$<.01$

$<.01$

$<.01$

$<.01$

$<.01$

$<.01$

$<.01$

$<.01$

$<.01$

$<.01$ 
Table 6. Results of water-quality analyses, grouped according to land-use areas, unsaturated-zone lithology, and type of well sampled-Continued

\begin{tabular}{|c|c|c|c|c|c|c|c|c|c|c|}
\hline $\begin{array}{l}\text { Well number } \\
\text { (latitude, longitude, } \\
\text { sequence number) }\end{array}$ & County & $\begin{array}{l}\text { Date of collection } \\
\text { (month-day-year) }\end{array}$ & $\begin{array}{c}\text { Specific } \\
\text { conductance } \\
\mu \mathrm{S} / \mathrm{cm})\end{array}$ & $\begin{array}{c}\mathrm{pH} \\
\text { (standard units) }\end{array}$ & $\begin{array}{l}\text { Temperature, } \\
\text { water (deg C) }\end{array}$ & $\begin{array}{l}\text { Hardness, tolal } \\
\left(\mathrm{mg} / \mathrm{L} \text { as } \mathrm{CaCO}_{3}\right)\end{array}$ & $\begin{array}{c}\text { Hardness, } \\
\text { noncarbonate } \\
\left(\mathrm{mg} / \mathrm{L} \text { as } \mathrm{CaCO}_{3}\right)\end{array}$ & $\begin{array}{c}\text { Alkalinity, } \\
\text { (mg/L as } \mathrm{CaCO}_{3}\end{array}$ & $\begin{array}{l}\text { Solids, sum } \\
\text { of constituents, } \\
\text { dissolved (mg/L) }\end{array}$ & $\begin{array}{l}\text { Calcium, } \\
\text { dissolved } \\
\text { (mg/L as Ca) }\end{array}$ \\
\hline
\end{tabular}

Areas of irrigated cropland (irrigation wells)

CLAYEY LITHOLOGY

\begin{tabular}{|c|c|c|c|}
\hline 381715098443501 & Barton & $07-21-87$ & 53 \\
\hline 375758099193901 & Edwards & $07-15-87$ & 3 \\
\hline 375521099165501 & Edwards & $07-15-87$ & \\
\hline 375057099141201 & Edwards & $07-22-87$ & \\
\hline 374434099115601 & Edwards & $07-22-87$ & \\
\hline 374416099275101 & Edwards & $07-27-87$ & \\
\hline 375843097334001 & Harvey & $07-22-87$ & 4 \\
\hline 375616097314901 & Harvey & $07-20-87$ & \\
\hline 373826099080401 & Kiowa & $07-22-87$ & 3 \\
\hline 382106097415501 & McPherson & $07-21-87$ & \\
\hline 381620097444101 & McPherson & $07-14-87$ & \\
\hline 380612099043601 & Pawnee & $07-20-87$ & \\
\hline 380549099074101 & Pawnee & $07-14-87$ & \\
\hline 374648098540701 & Pratt & $07-20-87$ & 4 \\
\hline 374324098534201 & Pratt & $07-21-87$ & \\
\hline 373509098333401 & Pratt & $07-21-87$ & \\
\hline 372922098292501 & Pratt & $07-22-87$ & \\
\hline 375810097534001 & Reno & $07-22-87$ & \\
\hline \multicolumn{4}{|c|}{ SANDY LTTHOLOGY } \\
\hline 375336099204501 & Edwards & $07-15-87$ & 3 \\
\hline 374909099274901 & Edwards & $07-23-87$ & 1,7 \\
\hline 375735097382401 & Harvey & $07-20-87$ & 1,0 \\
\hline 374209098122101 & Kingman & $07-23-87$ & 4 \\
\hline 374311099190101 & Kiowa & $07-22-87$ & \\
\hline 374018099070301 & Kiowa & $07-21-87$ & \\
\hline 374316099070401 & Kiowa & $07-22-87$ & \\
\hline 374729098014301 & Reno & $07-27-87$ & 3 \\
\hline 375256097333801 & Sedgwick & $07-22-87$ & 1,0 \\
\hline 375223097275401 & Sedgwick & $07-22-87$ & 7 \\
\hline 374843097323401 & Sedgwick & $07.21-87$ & \\
\hline 801270084356301 & BlnfTord & $07 \cdot 15-87$ & B \\
\hline
\end{tabular}

$7.5 \quad 14.5$

$\begin{array}{lll}7.4 & 15.0 & 200\end{array}$

$\begin{array}{lll}7.6 & 15.0 & 190\end{array}$

14.5

15.5
16.0

16.0

17.5
15.0
16.5

15.0

16.0
14.0

14.5

15.0

16.0

15.0

16.5

14.5

15.0

15.5

15.0
15.0

15.0

15.0

15.6

15.5

15.5

15.0
14.5

170

220

160

190

130

270

330

170

200

180
120

170

170
260
220

170

650
320
180

160

140

110

130

330
280

170

260

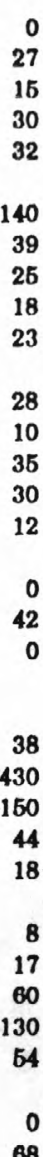

68

\begin{tabular}{|c|c|c|}
\hline 210 & 268 & 52 \\
\hline 140 & 221 & 68 \\
\hline 190 & 290 & 67 \\
\hline 160 & 288 & 63 \\
\hline 140 & 207 & 59 \\
\hline 83 & 393 & 71 \\
\hline 120 & 301 & 49 \\
\hline 160 & 397 & 68 \\
\hline 120 & 206 & 46 \\
\hline 240 & 345 & 92 \\
\hline 300 & 495 & 99 \\
\hline 160 & 324 & 50 \\
\hline 160 & 308 & 67 \\
\hline 150 & 260 & 65 \\
\hline 110 & 191 & 43 \\
\hline 170 & 258 & 59 \\
\hline 220 & 327 & 92 \\
\hline 230 & 359 & 74 \\
\hline 130 & 236 & 56 \\
\hline 220 & 1,220 & 180 \\
\hline 170 & 569 & 97 \\
\hline 140 & 284 & 66 \\
\hline 130 & 207 & 50 \\
\hline 130 & 223 & 47 \\
\hline 88 & 172 & 39 \\
\hline 68 & 235 & 41 \\
\hline 200 & 600 & 100 \\
\hline 230 & 434 & 91 \\
\hline 180 & 541 & 53 \\
\hline 200 & 174 & 86 \\
\hline
\end{tabular}


Table 6. Results of water-quality analyses, grouped according to land-use areas, unsaturated-zone lithology, and type of well sampled-Continued

\begin{tabular}{|c|c|c|c|c|c|c|c|c|c|c|}
\hline $\begin{array}{l}\text { Well number } \\
\text { (latitude, longitude) } \\
\text { sequence number) }\end{array}$ & County & $\begin{array}{c}\text { Magnexium, } \\
\text { dissolved } \\
\text { (mg/L as } \mathrm{Mg} \text { ) }\end{array}$ & $\begin{array}{c}\text { Sodium, } \\
\text { dissolved } \\
\text { (mg/L as Na) }\end{array}$ & $\begin{array}{l}\text { Potassium, } \\
\text { dissolved } \\
\text { (mg/L as K) }\end{array}$ & $\begin{array}{c}\text { Sulfate, } \\
\text { dissolved } \\
\left(\mathrm{mg} / \mathrm{has} \mathrm{SO}_{4}\right)\end{array}$ & $\begin{array}{l}\text { Chloride, } \\
\text { dissolved } \\
\text { (mg/L as Cl) }\end{array}$ & $\begin{array}{l}\text { Fluoride, } \\
\text { dissolved } \\
(\mathrm{mg} / \mathrm{L} \text { as } \mathrm{F})\end{array}$ & $\begin{array}{c}\text { Silica, } \\
\text { dissolved } \\
\left(\mathrm{mg} / \mathrm{L} \text { as } \mathrm{SiO}_{2}\right)\end{array}$ & $\begin{array}{c}\text { Nitrogen, } \\
\mathrm{NO}_{2}+\mathrm{NO}_{3}, \\
\text { dissolved } \\
\text { (mg/ as } \mathrm{N})\end{array}$ & $\begin{array}{l}\text { Phosphorus, } \\
\text { ortho, } \\
\text { dissolved } \\
\text { (mg/L as } \mathrm{P} \text { ) }\end{array}$ \\
\hline
\end{tabular}

Areas of irrigated cropland (irrigation wells)--Continued

CLAYEY LITHOLOGY

\begin{tabular}{|c|c|c|c|}
\hline 381715098443501 & Barton & 5.2 & 9.2 \\
\hline 375758099193901 & Edwards & 6.4 & 7.3 \\
\hline 375521099165501 & Edwards & 8.5 & 19 \\
\hline 375057099141201 & Edwards & 7.6 & 19 \\
\hline 374434099115601 & Edwards & 5.7 & 12 \\
\hline 374416099275101 & Edwards & 11 & 27 \\
\hline 375843097334001 & Harvey & 8.4 & 32 \\
\hline 375616097314901 & Harvey & 10 & 93 \\
\hline 373826099080401 & Kiowa & 4.8 & 12 \\
\hline 382106097415501 & McPherbon & 9.0 & 18 \\
\hline 381620097444101 & McPherson & 19 & 49 \\
\hline 380612099043601 & Pawnee & 10 & 45 \\
\hline 380549099074101 & Pawnee & 7.7 & 22 \\
\hline 374648098540701 & Pratt & 4.6 & 10 \\
\hline 374324098534201 & Pratt & 3.3 & 8.5 \\
\hline 373509098333401 & Pratt & 6.0 & 25 \\
\hline 372922098292501 & Pratt & 7.2 & 12 \\
\hline 375810097534001 & Reno & 8.1 & 40 \\
\hline
\end{tabular}

$\begin{array}{ccc}14 & 6.4 & 0.4 \\ 16 & 5.0 & \\ 20 & 8.1 & 11 \\ 27 & 7.1 & \\ 13 & 22 \\ 130 & 13 & \\ 100 & 44 & 5.6 \\ 68 & 21\end{array}$

0.4
.3
.5
.6
.5

23
26
23
20
22

7.2

6.7

9.3

.43

13

$<.10$

6.2

.74

6.0

$<.10$

12

9.3

11

9.0

10
9.6

375810097534001 Reno

8.1

24

16

SANDY LITHOLOGY

375336099204501

Edwarda

374909099274901

Edwards

Harvey

375735097382401

Kingman

6.6

12

374209098122101

Kiowe

48

150
100

374311099190101

Kiowa

374316099070401

Kiowa

Reno

375256097333801

Sedgwick

5.0

21

375223097275401

Sedgwick

30
600
110
13
11
12
9.4
19
100
96
60
24

4.7
64
120
18
5.9
6.2
3.4
11
110
38
130
110


Table 6. Results of water-quality analyses, grouped according to land-use areas, unsaturated-zone lithology, and type of well sampled--Continued

\begin{tabular}{|c|c|c|c|c|c|c|c|c|c|c|}
\hline $\begin{array}{l}\text { Well number } \\
\text { (latitude, longitude, } \\
\text { sequence number) }\end{array}$ & County & $\begin{array}{c}\text { Iron, } \\
\text { dissolved } \\
(\mu \mathrm{g} / \mathrm{L} \text { as } \mathrm{Fe})\end{array}$ & $\begin{array}{c}\text { Manganese, } \\
\text { dissolved } \\
(\mu \mathrm{g} / \mathrm{L} \text { as } \mathrm{Mn})\end{array}$ & $\begin{array}{l}\text { Alachlor, } \\
\text { total }(\mu g / L)\end{array}$ & $\begin{array}{l}\text { Ametryne, } \\
\text { tolal }(\mu \mathrm{g} / \mathrm{L})\end{array}$ & $\begin{array}{l}\text { Atrazine, } \\
\text { total }(\mu \mathrm{g} / \mathrm{L})\end{array}$ & $\begin{array}{l}\text { Cyanazine, } \\
\text { total }(\mu g / L)\end{array}$ & $\begin{array}{l}\text { Metolachlor, } \\
\text { total }(\mu \mathrm{g} / \mathrm{L})\end{array}$ & $\begin{array}{l}\text { Metriburin, } \\
\text { total }(\mu \mathrm{g} / \mathrm{L})\end{array}$ & $\begin{array}{l}\text { Prometone, } \\
\text { total }(\mu \Phi / L)\end{array}$ \\
\hline
\end{tabular}

Areas of irrigated cropland (irrigation wells)-.-Continued

CLAYEY LITHOLOGY

$375758099193901 \quad$ Edwands

375521099165501

375057099141201

374434099115601 Edwands

$<3$

$374416099275101 \quad$ Edwards

Edwards

375616097314901

Harvey

382106097415501

Kiowa

381620097444101

McPherson

380612099043601

McPherson

80549099074101

Pawnee

38054809074101

Pawnee

374324098534201

Pratt

Pratt

37350909833340

Pratt

372922098292501

Pratl

375810097534001

Reno

SANDY LITHOLOGY

375336099204501 Edwards

374909099274901

Edwards

375735097382401

Harvey

374209098122101

Kingman

37431109919010

Kiowa

$374018099070301 \quad$ Kiowa

37472909014301

Reno

375256097333801

Sedgwick

375223097275401

Sedgwick

$<0.10$

$<.10$

$<.10$

$<.10$
$<.10$

$<.10$
$<.10$

$<.10$

$<.10$

$<.10$

$<.10$

$<.10$

$<.10$

$<.10$

$<.10$

$<.10$

$<.10$

$<10$

$<.10$

$<.10$

$<.10$

$<.10$

$<.10$

$<.10$

$<.10$

$<.10$

.10
$<.10$

$<.10$

$<10$

\section{$<0.10$ \\ $<0.10$}

$<.10$

$<.10$

$<.10$
$<.10$

$<.10$
$<.10$

$<.10$

$<.10$

$<.10$

$<.10$
$<.10$
$<.10$

$<.10$

$<.10$

$<.10$

$<.10$
$<.10$
$<.10$

$<.10$

$<.10$

$<.10$

$<.10$

$<.10$

$<.10$

$<.10$
$<.10$

$<.10$

$<.10$

$<.10$

$<.10$

$<.10$
$<.10$
$<.10$

$<.10$

$<.10$
$<.10$

1.4

$<.10$

$<.10$

$<.10$

$<.10$

.10

$<.10$

$<.10$

$<.10$
$<.10$

$<.10$
$<.10$

$<.10$

$<.10$

$<.10$

$<.10$

$<.10$

$<10$

$<.10$

$<.10$
$<.10$

.30

$<.10$

$<.10$

$<.10$
$<.10$

\section{$<0.10$}

$<.10$

$<.10$

$<.10$

$<.10$

$<.10$

$<.10$

$<.10$

$<.10$

$<.10$

$<.10$

$<.10$

$<.10$

$<.10$

$<.10$

$<.10$

$<.10$

$<.10$

$<.10$

$<.10$

$<.10$

$<.10$

$<.10$

$<.10$

$<.10$

$<.10$

$<.10$

$<.10$

$<.10$

$<.10$

$\begin{array}{lll}<0.1 & <0.1 & <0.1 \\ <.1 & <.1 & <.1 \\ <.1 & <.1 & <.1 \\ <.1 & <.1 & <.1 \\ <.1 & <.1 & <.1 \\ & & \\ .1 & <.1 & <.1 \\ <.1 & <.1 & <.1 \\ <.1 & <.1 & <.1 \\ <.1 & <.1 & <.1 \\ <.1 & <.1 & <.1 \\ & & <.1 \\ <.1 & <.1 & <.1 \\ <.1 & <.1 & <.1 \\ <.1 & <.1 & <.1 \\ <.1 & <.1 & <.1 \\ <.1 & <.1 & <.1 \\ <.1 & <.1 & <.1 \\ <.1 & <.1 & <.1 \\ <.1 & <.1 & <.1 \\ <.1 & & \end{array}$

0.1

$<.1$

$<.1$

$<.1$

$<.1$

$<.1$

$<.1$

$<.1$

$<.1$

380127098435601 Stafford

$<1$

(3)

$<.1$
$<.1$
$<.1$
$<.1$
$<.1$

$<.1$
$<.1$
$<.1$
1.0
$<.1$
$<.1$
$<.1$

\begin{tabular}{|c|c|}
\hline$<.1$ & $<.1$ \\
\hline$<.1$ & $<.1$ \\
\hline$<.1$ & $<.1$ \\
\hline$<.1$ & $<.1$ \\
\hline$<.1$ & $<.1$ \\
\hline$<.1$ & $<.1$ \\
\hline$<.1$ & $<.1$ \\
\hline$<.1$ & <.1 \\
\hline$<.1$ & $<.1$ \\
\hline$<.1$ & $<.1$ \\
\hline$<.1$ & $<.1$ \\
\hline$<.1$ & $<.1$ \\
\hline
\end{tabular}


Table 6. Results of water-quality analyses, grouped according to land-use areas, unsaturated-zone lithology, and type of well sampled--Continued

\begin{tabular}{|c|c|c|c|c|c|c|c|c|c|c|}
\hline $\begin{array}{l}\text { Well number } \\
\text { (latitude, longitude, } \\
\text { sequence number) }\end{array}$ & County & $\begin{array}{l}\text { Prometryne, } \\
\text { total }(\mu \mathrm{g} / \mathrm{L})\end{array}$ & $\begin{array}{l}\text { Propazine, } \\
\text { total }(\mu \mathrm{h} / \mathrm{L})\end{array}$ & $\begin{array}{l}\text { Silvex, } \\
\text { total }(\mu g / L)\end{array}$ & $\begin{array}{l}\text { Simazine, } \\
\text { total }(\mu g / 1)\end{array}$ & $\begin{array}{l}\text { Simetryne, } \\
\text { total }(\mu g / L)\end{array}$ & $\begin{array}{l}\text { Trifluralin, } \\
\text { total }(\mu g / L)\end{array}$ & $\begin{array}{l}\text { 2,4-D, } \\
\text { total }(\mu \mathrm{g} / \mathrm{L})\end{array}$ & $\begin{array}{l}\text { 2,4-DP, } \\
\text { total }(\mu \mathrm{g} / \mathrm{L})\end{array}$ & $\begin{array}{c}2,4,5-\mathrm{T} \\
\operatorname{total}(\mu \mathrm{g} / \mathrm{L})\end{array}$ \\
\hline
\end{tabular}

Areas of irrigated cropland (irrigation wells)--Continued

CLAYEY LITHOLOGY

381715098443501

$375758099193901 \quad$ Edwards

$375521099165501 \quad$ Edward

$375057099141201 \quad$ Edwarda

$374434099115601 \quad$ Edwards

$<0.10$
$<.10$
$<.10$
$<.10$
$<.10$

$<0.01$

$<.01$

$<.01$

$<.01$

$<.01$

$<.10$

374416099275101

375843097334001

Edwards

$<.1$

375616097314901

Harvey

.10
$<.10$

37382609908040

Harvey

$<.1$

382106097415501

Kiowa

$<.10$

$<.01$

$<.01$

$<.01$

$<.01$

$<.10$

$<.01$

38620097444101

McPherson

$<.1$

380549099074101

Pawnee

$<.10$

37464809854070

Pawnee

$<.1$

374324098534201

Pratt

$<.10$

$<.01$

$<.01$

..

373509098333401

372922098292501

Pratt

37581009753400

Pratt

$<.1$

$<.10$

$<.10$

..

$<.10$
$<.10$

$<.1$

SANDY LITHOLOGY

375336099204501

Edwards

$<.1$

$<.01$

$<.01$

$<0.1$

$<.1$

$<.10$

$<.10$

$<.1$

$<.1$

$<.10$

$<.10$
$<.10$

$<.10$

$<.10$

$<.1$

$<.1$
$<.1$
$<.1$

$<.1$

$<.10$
$<.10$

$<.10$

$<.10$

$<.10$
$<.10$

$<.1$

$<.1$
$<.1$
$<.1$

$<.1$

$<.10$

$<.10$

$<.1$

c.10

$<.10$

$<.1$

$<0.10$

$<.10$

$<.10$

$<.10$

$<.01$
$<.01$
$<.01$
$<.01$
$<.01$

$<.01$
$<.01$
$<.01$
$<.01$
$<.01$
$<.01$
$<.01$
$<.01$
.
..
.

$0.01<0.01$

$<.10$

$<.01$

$<.10$

$<.01$

375735097382401

Edwards

$<.1$
$<.1$
$<.1$

$<.10$

$<.01$

$<.10$
$<.10$
$<.10$

$<.10$

$<.01$

374311099190101

Kingman

$<.10$

$<.01$

$<.10$

$<.1$
$<.1$
$<.1$
$<.1$
$<.1$

$<.01$

$<.10$
$<.10$

374316099070401

Kiowa

374729098014301

$<.1$

37.

Reno

375223097275401

Bedgwick

$<.10$

$<.01$

$<.01$

$<.10$
$<.10$

$<.01$

$<.10$
$<.10$

$<.01$

380127098450

Sedgwick

$<.1$

$<.01$

$<.10$

$<.10$
$<.10$
$<.10$

$<.10$

$<.10$

$<.10$

$<.10$

$<.10$

$<.10$

$<.10$

$<.10$

.10
$<.10$

$<.10$

$<.10$

$<.01$

$<.01$

$$
<.01
$$

$<.01$
$<.01$

$<.01$

$<.01$

$<.01$

$$
<.01
$$$$
\begin{aligned}
& <.01 \\
& <.01
\end{aligned}
$$

$$
<.01
$$

$$
<.01
$$

$<01$

$<.01$

$<.01$

$<.01$
$<.01$

$<.01$

$<.01$

-

$<.01$

$<.01$

$<.01$

$<.10$
$<10$

$<.10$

$<.10$

$<.10$

$<.10$

$<.10$

$<.01$

$<.01$

$<.01$

$<.01$

$<.01$
$<.01$

$<.01$

$<.01$

$<.01$

$<.01$

$<.01$

$<.01$

$<.1 \quad<.10$

$<.10$

$<.01$

$<.01$

$<.01$

$<.10$

$<.10$

$<.01$

$<.01$

$<.01$

$<.01$

$\begin{array}{ll}<.1 & <.10 \\ <.1 & <.10\end{array}$

$<.01$

$<01$

$<.01$

$<.01$

$<.10$
$<.10$

$<.01$

$<.01$

$<.01$ 
Table 6. Results of water-quality analyses, grouped according to land-use areas, unsaturated-zone lithology, and type of well sampled--Continued

\begin{tabular}{|c|c|c|c|c|c|c|c|c|c|c|}
\hline $\begin{array}{l}\text { Well number } \\
\text { (latitude, longitude, } \\
\text { sequence number) }\end{array}$ & County & $\begin{array}{l}\text { Date of collection } \\
\text { (month-day-year) }\end{array}$ & $\begin{array}{c}\text { Specific } \\
\text { conductance } \\
(\mu \mathrm{S} / \mathrm{cm})\end{array}$ & $\begin{array}{c}\mathrm{pH} \\
\text { (standard units) }\end{array}$ & $\begin{array}{l}\text { Temperature, } \\
\text { water (deg C) }\end{array}$ & $\begin{array}{l}\text { Hardness, } \\
\text { total }(\mathrm{mg} / \mathrm{L} \\
\left.\text { as } \mathrm{CaCO}_{3}\right)\end{array}$ & $\begin{array}{c}\text { Hardness, } \\
\text { noncarbonate } \\
\left.\text { (mp/l as } \mathrm{CaCO}_{3}\right)\end{array}$ & $\begin{array}{c}\text { Alkalinity, } \\
\text { (mg/L as } \\
\left.\text { as } \mathrm{CaCO}_{3}\right)\end{array}$ & $\begin{array}{l}\text { Solids, sum of } \\
\text { constituents, } \\
\text { dissolved } \\
(\mathrm{mg} / \mathrm{L})\end{array}$ & $\begin{array}{l}\text { Calcium, Magnesium, } \\
\text { dissolved dissolvod } \\
(\mathrm{mg} / \mathrm{Las} \mathrm{Ca})(\mathrm{mg} / \mathrm{Las} \mathrm{Mg})\end{array}$ \\
\hline
\end{tabular}

CLAYEY LITHOLOGY

\begin{tabular}{|c|c|c|c|c|c|}
\hline \multirow{2}{*}{\multicolumn{6}{|c|}{372553098133701}} \\
\hline & & & & & \\
\hline 372302098143601 & Kingman & $07.29-87$ & 677 & 7.1 & 16.0 \\
\hline 374021099304901 & Kiowa & $07-28-87$ & 295 & 7.3 & 15.0 \\
\hline 382425097290101 & McPherson & $07-13-87$ & 481 & 7.0 & 17.0 \\
\hline 375619097494101 & Reno & $07-28-87$ & 754 & 7.4 & 16.0 \\
\hline 381358098045301 & Rice & $07-08-87$ & 824 & 7.3 & 16.0 \\
\hline 381629098023601 & Rice & $07-14-87$ & 503 & 7.3 & 14.0 \\
\hline 381140098345101 & Stafford & $07-09-87$ & 657 & 7.5 & 18.5 \\
\hline 375231098561901 & Stafford & $07-30-87$ & 134 & 7.7 & 15.0 \\
\hline \multicolumn{6}{|c|}{ SANDY LITHOLOGY } \\
\hline 381819098330101 & Barton & $07-07-87$ & 1,470 & 7.4 & 15.0 \\
\hline 381707098290901 & Barton & $07-08-87$ & 935 & 7.2 & 17.0 \\
\hline 373124097591201 & Kingman & $07-29-87$ & 485 & 7.0 & 27.0 \\
\hline 373048098015401 & Kingman & $07.29-87$ & 373 & 7.1 & 16.0 \\
\hline 380249099133401 & Pawnee & $07-09-87$ & 625 & 7.3 & 15.0 \\
\hline 374207098394801 & Pratt & $07-30-87$ & 645 & 7.8 & 17.0 \\
\hline 381411098311901 & SlafTord & $07-08-87$ & 560 & 7.5 & 15.0 \\
\hline 380916098315101 & Stafford & $07-13-87$ & 743 & 7.7 & 14.5 \\
\hline 380731098315101 & Stafford & $07-14-87$ & 229 & 6.8 & 14.0 \\
\hline 380631098361401 & Stafford & $07-14-87$ & 392 & 7.6 & 14.5 \\
\hline 380553098341801 & Stafford & $07-14-87$ & 1,190 & 7.9 & 14.5 \\
\hline 375625098444601 & SLafford & $07-15-87$ & 369 & 7.5 & 17.0 \\
\hline 375310098523701 & Stafford & $07 \cdot 16-87$ & 587 & 7.2 & 15.5 \\
\hline
\end{tabular}

Areas of petroleum-production land

$\begin{array}{ll}70 & 470 \\ 60 & 4 \\ 20 & \\ 90 & \\ 90 & 10 \\ & \\ 30 & \\ 20 & 39 \\ 60 & \end{array}$

$470-100$

$\begin{array}{rc}170 & 35 \\ 93 & 6.6 \\ 40 & 4.9 \\ 64 & 6.6 \\ 97 & 11 \\ & \\ 37 & 34 \\ 78 & 7.2 \\ 66 & 5.4 \\ 65 & 4.5\end{array}$

$540-130$

$\begin{array}{rr}130 & 420 \\ 150 & 140 \\ 53 & 120 \\ 1 & 120 \\ 120 & 140 \\ & \\ 47 & 160 \\ 3 & 180 \\ 0 & 220 \\ 13 & 77 \\ 0 & 160 \\ 0 & \\ 0 & 190 \\ 19 & 130 \\ 84 & 160\end{array}$

1,120
520
280
196
375

341
343
416
149
229
646
224
329

180
96
54
41
86
73
64
44
31
68
33
54
87


Table 6. Results of water-quality analyses, grouped according to land-use areas, unsaturated-zone lithology, and type of well sampled--Continued

\begin{tabular}{|c|c|c|c|c|c|c|c|c|c|c|}
\hline $\begin{array}{l}\text { Well number } \\
\text { (latitude, longitude, } \\
\text { sequence number) }\end{array}$ & County & $\begin{array}{c}\text { Sodium, } \\
\text { dissolved } \\
\text { (mg/L as Na) }\end{array}$ & $\begin{array}{l}\text { Potassium, } \\
\text { dissolved } \\
\text { (mg/h as } \mathrm{K})\end{array}$ & $\begin{array}{c}\text { Sulfate, } \\
\text { dissolved } \\
\left(\mathrm{mg} / \mathrm{L} \text { as } \mathrm{SO}_{4}\right)\end{array}$ & $\begin{array}{c}\text { Chloride, } \\
\text { dissolved } \\
\text { (mg/L as Cl) }\end{array}$ & $\begin{array}{l}\text { Fluoride, } \\
\text { dissolved } \\
(\mathrm{mg} / \mathrm{Las} \text { F) }\end{array}$ & $\begin{array}{c}\text { Silica, } \\
\text { dissolved } \\
\left(\mathrm{mg} / \mathrm{L} \text { as } \mathrm{SiO}_{2}\right)\end{array}$ & $\begin{array}{c}\text { Nitrogen, } \\
\mathrm{NO}_{2}+\mathrm{NO}_{3}, \\
\text { dissolved } \\
\text { (mg/ as } \mathrm{N})\end{array}$ & $\begin{array}{l}\text { Phosphorus, } \\
\text { ortho, } \\
\text { dissolved } \\
\text { (mg/L as P) }\end{array}$ & $\begin{array}{l}\text { Mangancse, } \\
\text { Iron, dissolved } \\
\text { dissolved }(\mu \mathrm{g} / \mathrm{L} \\
(\mu \mathrm{g} / \mathrm{L} \text { as } \mathrm{Fe}) \text { as } \mathrm{Mn})\end{array}$ \\
\hline
\end{tabular}

Areas of petroleum-production land--Continued

\section{CLAYEY LITHOLOGY}

372553098133701

372302098143601 Kingman

374021099304901 Kiowa

382425097290101 McPherson

375619097494101 Reno

$\begin{array}{ll}\mathbf{3 8 1 3 5 8 0 9 8 0 4 5 3 0 1} & \text { Rice } \\ \mathbf{3 8 1 6 2 9 0 9 8 0 2 3 6 0 1} & \text { Rice } \\ \mathbf{3 8 1 1 4 0 0 9 8 3 4 5 1 0 1} & \text { Stafford } \\ \mathbf{3 7 5 2 3 1 0 9 8 5 6 1 9 0 1} & \text { Staftord }\end{array}$

87

Stafford

\section{SANDY LITHOLOGY}

SANDYLITHOLOG

Kingman

Kingman

Pawnee

374207098394801

381411098311901

380916098315101

Pratt

380731098315101

Staftord

Stafford

88063109

Stafford

38055309834180

375625098444601

Staffor

Stafford
180

34

14
31

36

100

18

37
9.6

9.6

180

86

18

17

22

38

40

110

200

13
66

27
15

21

91

39
9.4

12

160
41
21
9.1
21

14
9.8
12
13
17
22
12
10

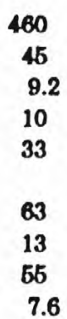

460
45
9.2
10

10

63

13
55

7.6

290
150
10
16
91
78
77
86
3.2
10
240
7.9
64

21
24
25
21
25

2.8
28
23
26

21
25

2.8

28
23

26

24

22
25

25

24

20

22

27

18

21

22
25
23
5.3
2.0
1.6
6.0

1.6
4.7
3.6
5.6

2.5
6.1
15
1.4
7.1

3.4
3.3
.46
3.6
.91

2.5
6.8
3.7

$<0.01$
.03
.08
.09
.04

.14
.07
.05
.09

$\begin{array}{rr}40 & <10 \\ 130 & 2 \\ <3 & <1 \\ 49 & 7 \\ 9 & 1\end{array}$

$6 \quad 25$

250
$<1$
$<1$

$<1$

.02
.04
.08
.09
.05
03
.03
.07
.03
.09
.05
.10
.06
.08

$\begin{array}{rr}34 & 380 \\ 10 & <1 \\ 77 & 5 \\ 570 & 18 \\ <3 & 1 \\ 85 & 4 \\ 8 & <1 \\ 3 & 2 \\ 8 & <1 \\ 640 & 110 \\ & \\ 10 & <1 \\ <3 & <1 \\ 6 & <1\end{array}$


Table 6. Results of water-quality analyses, grouped according to land-use areas, unsaturated-zone lithology, and type of well sampled--Continued

\begin{tabular}{|c|c|c|c|c|c|c|c|c|c|c|}
\hline $\begin{array}{l}\text { Well number } \\
\text { (atitude, longitude, } \\
\text { soquence number) }\end{array}$ & County & $\begin{array}{l}\text { Date of collection } \\
\text { (month-day-year) }\end{array}$ & $\begin{array}{c}\text { Specific } \\
\text { conductance } \\
(\mu \mathrm{S} / \mathrm{cm})\end{array}$ & $\begin{array}{c}\mathrm{pH} \\
\text { (standard units) }\end{array}$ & $\begin{array}{l}\text { Tempera ture, } \\
\text { water (deg C) }\end{array}$ & $\begin{array}{l}\text { Hardness, } \\
\text { total }(m g / \\
\left.\text { as } \mathrm{CaCO}_{3}\right)\end{array}$ & $\begin{array}{c}\text { Hardness, } \\
\text { noncarbonate } \\
\text { (mp/L } \\
\text { as } \mathrm{CaCO}_{3} \text { ) }\end{array}$ & $\begin{array}{c}\text { Alkalinity } \\
\left(\mathrm{mg} / \mathrm{L} \text { as } \mathrm{CaCO}_{3}\right)\end{array}$ & $\begin{array}{l}\text { Bolids, } \\
\text { sum of } \\
\text { constituents, } \\
\text { dissolved } \\
(\mathrm{mg} / \mathrm{L})\end{array}$ & $\begin{array}{c}\text { Calcium, } \\
\text { dissolved } \\
\text { (mg/ as Ca) }\end{array}$ \\
\hline
\end{tabular}

Areas of rangeland

CLAYEY LITHOLOGY

375204 LITHOLOC

374708099263501

Edwands

Edwards

Kiowa

(373343099075501

374338099102901

Kiowa

McPherson

Pratt

Reno

374314098581201

380955098234101

381029097591901

Rice

SANDY LITHOLOGY

375345099223201

Edwards

374215098262101

Kingman

Kiowa

(7)

Kiowa

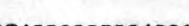

375646098381001

380845097545101

Pratt

Pratt

380746097514802

Reno

Reno

380350097463301

Reno

375327098193401

380632098231401

Reno

Reno

Rice

\begin{tabular}{|rr}
\hline $07-28-87$ & 335 \\
$07-28-87$ & 585 \\
$07-28-87$ & 290 \\
$07-29-87$ & 365 \\
$07-29-87$ & 250 \\
& \\
$07-13-87$ & 1,600 \\
$07-30-87$ & 268 \\
$07-16-87$ & 1,990 \\
$07-09-87$ & 176 \\
& \\
$07-28-87$ & 316 \\
$07-24-87$ & 297 \\
$07-28-87$ & 219 \\
$07-29-87$ & 248 \\
$07-15-87$ & 465 \\
\hline $07-30-87$ & 703 \\
$07-30-87$ & 456 \\
$07-28-87$ & 223 \\
$07-28-87$ & 280 \\
$07-29-87$ & 156 \\
\hline $07-15-87$ & 865 \\
$07-15-87$ & 1,960 \\
$07-16-87$ & 188
\end{tabular}

\begin{tabular}{rrr}
7.4 & 17.0 & 130 \\
7.5 & 15.5 & 220 \\
6.8 & 15.0 & 89 \\
6.9 & 15.5 & 190 \\
6.9 & 15.0 & 110 \\
& & \\
7.2 & 16.5 & 710 \\
7.5 & 16.0 & 100 \\
7.0 & 16.0 & 240 \\
6.0 & 16.0 & 63 \\
& & \\
6.0 & 15.5 & 140 \\
7.0 & 15.5 & 130 \\
7.3 & 16.0 & 99 \\
6.9 & 15.0 & 100 \\
7.5 & 18.0 & 210 \\
& & \\
7.8 & 16.0 & 310 \\
7.5 & 16.0 & 190 \\
6.9 & 16.0 & 76 \\
7.7 & 16.0 & 110 \\
6.4 & 16.0 & 31 \\
6.7 & & \\
7.0 & 14.5 & 320 \\
6.2 & 19.0 & 130 \\
\hline & 15.0 & 49
\end{tabular}

$\begin{array}{rr}21 & 110 \\ 100 & 120 \\ 33 & 56 \\ 12 & 180 \\ 23 & 86 \\ & \\ 300 & 420 \\ 31 & 71 \\ 0 & 250 \\ 10 & 43 \\ & \\ 34 & 110 \\ 33 & 96 \\ 6 & 93 \\ 22 & 81 \\ 23 & 190 \\ & \\ 110 & 200 \\ 35 & 160 \\ 0 & 76 \\ 6 & 110 \\ 3 & 28 \\ & \\ 250 & 69 \\ 0 & 160 \\ 3 & 46\end{array}$

$\begin{array}{rr}193 & 45 \\ 429 & 73 \\ 197 & 28 \\ 252 & 66 \\ 169 & 37 \\ & \\ 1,030 & 140 \\ 183 & 35 \\ 1,070 & 77 \\ 135 & 16 \\ & \\ & \\ 201 & 51 \\ 194 & 45 \\ 153 & 34 \\ 173 & 35 \\ 286 & 70 \\ & \\ 415 & 110 \\ 269 & 70 \\ 146 & 24 \\ 178 & 40 \\ 100 & 9.5 \\ & \\ 600 & 110 \\ 1,320 & 43 \\ 127 & 15\end{array}$


Table 6. Results of water-quality analyses, grouped according to land-use areas, unsaturated-zone lithology, and type of well sampled--Continued

\begin{tabular}{|c|c|c|c|c|c|c|c|c|c|c|}
\hline $\begin{array}{l}\text { Well number } \\
\text { (latitude, longitude, } \\
\text { sequence number) }\end{array}$ & County & $\begin{array}{c}\text { Magnesium, } \\
\text { dissolved } \\
\text { (mg/L as Mg) }\end{array}$ & $\begin{array}{c}\text { Sodium, } \\
\text { dissolved } \\
\text { (mpll as Na) }\end{array}$ & $\begin{array}{c}\text { Potassium, } \\
\text { dissolved } \\
\text { (mg/ as K) }\end{array}$ & $\begin{array}{c}\text { Sulfate, } \\
\text { dissolved } \\
\left(\mathrm{mg} / \mathrm{L} \text { as } \mathrm{SO}_{4}\right)\end{array}$ & $\begin{array}{c}\text { Chloride, } \\
\text { dissolved } \\
\text { (mg/L as Cl) }\end{array}$ & $\begin{array}{c}\text { Fluoride, } \\
\text { dissolved } \\
\text { (mg/L as F) }\end{array}$ & $\begin{array}{c}\text { Silica, } \\
\text { dissolved } \\
\left(\mathrm{mg} / \mathrm{L} \text { as } \mathrm{SiO}_{2}\right)\end{array}$ & $\begin{array}{l}\text { Nitrogen, } \\
\mathrm{NO}_{2}+\mathrm{NO}_{3} \text {, } \\
\text { dissolved } \\
(\mathrm{mg} / \mathrm{L} \mathrm{as} \mathrm{N})\end{array}$ & $\begin{array}{l}\text { Phosphorus, } \\
\text { ortho, } \\
\text { dissolved } \\
\text { (mg } / \text { as } P \text { ) }\end{array}$ \\
\hline
\end{tabular}

\section{CLAYEY LITHOLOGY}

2501 Edwards

Edwards

$374251099283901 \quad$ Kiowa

$373343099075501 \quad$ Kiows

374338099102901 Kiow日

382624097505801 McPherson

374314098581201 Pratt

380955098234101 Reno

Rice

SANDY LITHOLOGY

375345099223201 Edwards

374215098262101 Kingman

373923099325901 Kiow日

374116099022501 Kiow

380151099162601 Pawnee

374220098384201 Pratt

375646098381001 Pratt

380845097545101 Reno

380746097514802 Reno

380350097463301 Reno

375327098193401 Reno

380632098231401 Reno

381159098262101 Rice

$\begin{array}{lc}3.6 & 14 \\ 9.2 & 43 \\ 4.6 & 23 \\ 5.6 & 13 \\ 3.9 & 7.6 \\ 88 & 80 \\ 3.4 & 9.5 \\ 11 & 290 \\ 3.2 & 13\end{array}$

Areas of rangeland-Continued

\begin{tabular}{|c|c|c|c|c|c|}
\hline 28 & 7.9 & 0.4 & 19 & 2.5 & 0.03 \\
\hline 180 & 14 & .4 & 23 & 2.9 & .04 \\
\hline 54 & 14 & .2 & 25 & 3.0 & .10 \\
\hline 11 & 13 & .3 & 23 & 2.7 & .02 \\
\hline 12 & 4.6 & .3 & 27 & 5.0 & .17 \\
\hline 380 & 67 & .4 & 14 & 1.0 & $<.01$ \\
\hline 12 & 4.8 & .3 & 28 & 10 & .07 \\
\hline 72 & 430 & .4 & 20 & 3.8 & .10 \\
\hline 13 & 4.8 & .2 & 39 & 3.8 & .43 \\
\hline
\end{tabular}

$\begin{array}{cc}3.1 & 7.5 \\ 4.1 & 8.6 \\ 3.5 & 6.8 \\ 3.7 & 9.6 \\ 8.6 & 15 \\ & \\ 7.4 & 25 \\ 4.5 & 13 \\ 3.8 & 13 \\ 3.5 & 11 \\ 1.8 & 11 \\ & \\ 11 & 24 \\ 5.6 & 440 \\ 2.8 & 16\end{array}$

$\begin{array}{lc}24 & 8.0 \\ 16 & 2.7 \\ 12 & 3.1 \\ 10 & 3.7 \\ 32 & 7.9 \\ & \\ 19 & 70 \\ 14 & 7.3 \\ 14 & 4.1 \\ 10 & 3.5 \\ 11 & 3.2 \\ & \\ 34 & 84 \\ 65 & 620 \\ 13 & 11\end{array}$

18
25
26
27
23
23
21
31
32
30
22
22
29

$\begin{array}{ll}5.5 & .06 \\ 7.6 & .09 \\ 2.2 & .14 \\ 7.4 & .07 \\ 3.1 & .03 \\ & \\ 8.6 & .04 \\ 9.6 & .04 \\ 2.0 & .12 \\ 2.6 & .07 \\ 2.7 & .49 \\ & \\ 39 & .06 \\ 5.8 & <.01 \\ 2.5 & 10\end{array}$


Table 6. Results of water-quality analyses, grouped according to land-use areas, unsaturated-zone lithology, and type of well sampled--Continued

\begin{tabular}{|c|c|c|c|c|c|c|c|c|c|c|}
\hline $\begin{array}{l}\text { Well number } \\
\text { (latitude, longitude, } \\
\text { (sequence number) }\end{array}$ & County & $\begin{array}{c}\text { Iron, } \\
\text { dissolved } \\
\text { ( } \mu g / \mathrm{L} \text { as Fe) }\end{array}$ & $\begin{array}{c}\text { Manganese, } \\
\text { dissolved } \\
(\mu \mathrm{g} / \text { as } \mathrm{Mn})\end{array}$ & $\begin{array}{c}\text { Alachlor, } \\
\text { total } \\
(\mu g / L)\end{array}$ & $\begin{array}{c}\text { Ametryne, } \\
\text { total } \\
(\mu \nsubseteq / L)\end{array}$ & $\begin{array}{c}\text { Atrazine, } \\
\text { total } \\
(\mu \mathrm{g} / \mathrm{L})\end{array}$ & $\begin{array}{c}\text { Cyanazine, } \\
\text { total } \\
\text { ( } \mu \mathrm{gL})\end{array}$ & $\begin{array}{c}\text { Metolachlor, } \\
\text { total } \\
(\mu \mathrm{g} / \mathrm{L})\end{array}$ & $\begin{array}{c}\text { Metribuzin, } \\
\text { total } \\
(\mu g / L)\end{array}$ & $\begin{array}{c}\text { Prometone, } \\
\text { total } \\
(\mu g / L)\end{array}$ \\
\hline
\end{tabular}

Areas of rangeland--Continued

\section{CLAYEY LITHOI OGY}

375204090232501

Edwards

Kiowa

$373343099075501 \quad$ Kiows

374338099102901 Kiowa

382624097505801 McPherson

374314098581201

McPherso

Rice

SANDY LITHOLOGY

375345099223201 Edward

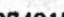

374215098262101

Edwards

Kingme

374116099022501

Kiows

380151099162601

Pawnee

3742009384201

37564609838100

380845097545101

Pratt

Pratt

380746097514802

$(10070097$

Reno

375327098193401

380632098231401

Reno

Rice

14
26
24
13
21

8
28
28
12

$<1$
1
1
2
1

2
2
2
$<1$

6

3

$<3$

210
$<3$

12

17

80

80
5

1
$<1$
$<1$
3
$<1$
1
3
2
2
$<1$
$<1$
10
2

$\begin{array}{lllllll}<.10 & <.10 & <.10 & <0.10 & <0.1 & <.1 & <0.1 \\ <.10 & <.10 & <.10 & <.10 & <.1 & <.1 & <.1 \\ <.10 & <.10 & <.10 & <.10 & <.1 & <.1 & <.1 \\ <.10 & <.10 & <.10 & <.10 & <.1 & <.1 & <.1 \\ <.10 & <.10 & <.10 & <.10 & <.1 & <.1 & <.1 \\ <.10 & <.10 & <.10 & <.10 & <.1 & <.1 & <.1 \\ <.10 & <.10 & <.10 & <.10 & <.1 & <.1 & <.1 \\ <.10 & <.10 & <.10 & <.10 & <.1 & <.1 & <.1 \\ <.10 & <.10 & <.10 & <.10 & <.1 & <.1 & <.1\end{array}$

$\begin{array}{llll}<.10 & <.10 & <.10 & <.10 \\ <.10 & <.10 & <.10 & <.10 \\ <.10 & <.10 & <.10 & <.10 \\ <.10 & <.10 & <.10 & <.10 \\ <.10 & <.10 & <.10 & <.10 \\ <.10 & <.10 & <.10 & <.10 \\ <.10 & <.10 & <.10 & <.10 \\ <.10 & <.10 & <.10 & <.10 \\ <.10 & <.10 & <.10 & <.10 \\ <.10 & <.10 & <.10 & <.10 \\ <.10 & <.10 & < & <.10 \\ <.10 & <.10 & <.10 & <.10 \\ <.10 & <.10 & <.10 & <.10\end{array}$

$<.1$
$<.1$
$<.1$
$<.1$
$<.1$
$<.1$
$<.1$
$<.1$
$<.1$
$<.1$
$<.1$
$<.1$
$<.1$

$<.1$
$<.1$
$<.1$
$<.1$
$<.1$
$<.1$
$<.1$
$<.1$
$<.1$
$<.1$
$<.1$

$<.1$
$<.1$
$<.1$
$<.1$
$<.1$

$<.1$
$<.1$
$<.1$
$<.1$
$<.1$

$<.1$
$<.1$
$<.1$

$<.1$
$<.1$
$<.1$
$<.1$

$<.1$
$<.1$
$<.1$
$<.1$
$<.1$

$<.1$
$<.1$
$<.1$


Table 6. Results of water-quality analyses, grouped according to land-use areas, unsaturated-zone lithology, and type of well sampled-.Continued

\begin{tabular}{|c|c|c|c|c|c|c|c|c|c|c|}
\hline $\begin{array}{l}\text { Well number } \\
\text { (latitude, longitude, } \\
\text { sequence number) }\end{array}$ & County & $\begin{array}{c}\text { Prometryne, } \\
\text { total } \\
(\mu \mathrm{g} / \mathrm{L})\end{array}$ & $\begin{array}{l}\text { Propazine, } \\
\text { total } \\
(\mu g / L)\end{array}$ & $\begin{array}{l}\text { Silvex, } \\
\text { total } \\
(\mu \mathrm{g} / \mathrm{L})\end{array}$ & $\begin{array}{c}\text { Simaxine, } \\
\text { total } \\
(\mu g / L)\end{array}$ & $\begin{array}{c}\text { Simetryne, } \\
\text { total } \\
(\mu \mathrm{g} / \mathrm{L})\end{array}$ & $\begin{array}{c}\text { Trifluralin, } \\
\text { total } \\
(\mu \mathrm{g} / \mathrm{L})\end{array}$ & $\begin{array}{c}2,4-D, \\
\text { Ltal } \\
(\mu g / L)\end{array}$ & $\begin{array}{c}2,4-D P \\
\text { total } \\
(\mu \mathrm{g} / L)\end{array}$ & $\begin{array}{c}2,4,5-\mathrm{T}, \\
\text { total } \\
(\mu \mathrm{g} / \mathrm{L})\end{array}$ \\
\hline
\end{tabular}

Areas of rangeland--Continued

CLAYEY LITHOLOGY

\begin{tabular}{|c|c|c|c|c|c|c|c|c|c|c|}
\hline \\
\hline 375204099232501 & Edwards & $<0.1$ & $<0.10$ & $<0.01$ & $<0.10$ & $<0.1$ & $<0.10$ & $<0.01$ & $<0.01$ & $<0.01$ \\
\hline 374708099263501 & Edwards & $<.1$ & $<.10$ & .. & $<.10$ & $<.1$ & $<.10$ & - & - & - \\
\hline 374251099283901 & Kiowa & $<.1$ & $<.10$ & $<.01$ & $<.10$ & $<.1$ & $<.10$ & $<.01$ & $<.01$ & $<.01$ \\
\hline 373343099075501 & Kiowa & $<.1$ & $<.10$ & $<.01$ & $<.10$ & $<, 1$ & $<.10$ & $<.01$ & $<.01$ & $<.01$ \\
\hline 374338099102901 & Kiowa & $<.1$ & $<.10$ & $<.01$ & $<.10$ & $<.1$ & $<.10$ & $<.01$ & $<.01$ & $<.01$ \\
\hline 382624097505801 & McPherson & $<.1$ & $<.10$ & $<.01$ & $<.10$ & $<.1$ & $<.10$ & $<.01$ & $<.01$ & $<.01$ \\
\hline 374314098581201 & Pratt & $<.1$ & $<.10$ & $<.01$ & $<.10$ & $<.1$ & $<.10$ & $<.01$ & $<.01$ & $<.01$ \\
\hline 380956098234101 & Reno & $<.1$ & $<.10$ & $<.01$ & $<.10$ & $<.1$ & $<.10$ & $<.01$ & $<.01$ & $<.01$ \\
\hline 381029097591901 & Rice & $<.1$ & $<.10$ & $<.01$ & $<.10$ & $<.1$ & $<.10$ & $<.01$ & $<.01$ & $<.01$ \\
\hline \multicolumn{11}{|c|}{ SANDY LITHOLOGY } \\
\hline 375345099223201 & Edwards & $<.1$ & $<.10$ & $<.01$ & $<.10$ & $<.1$ & $<.10$ & $<.01$ & $<.01$ & $<.01$ \\
\hline 374215098262101 & Kingman & $<.1$ & $<.10$ & .. & $<.10$ & $<.1$ & $<.10$ & - & - & - \\
\hline 373923099325901 & Kiowa & $<.1$ & $<.10$ & $<.01$ & $<.10$ & $<.1$ & $<.10$ & $<.01$ & $<.01$ & $<.01$ \\
\hline 374116099022501 & Kiowa & $<.1$ & $<.10$ & $<.01$ & $<.10$ & $<.1$ & $<.10$ & $<.01$ & $<.01$ & $<.01$ \\
\hline 380151099162601 & Pawnee & $<.1$ & $<.10$ & $<.01$ & $<.10$ & $<.1$ & $<.10$ & $<.01$ & $<.01$ & $<.01$ \\
\hline 374220098384201 & Pratt & $<.1$ & $<.10$ & $<.01$ & $<.10$ & $<.1$ & $<.10$ & $<.01$ & $<.01$ & $<.01$ \\
\hline 375646098381001 & Pratt & $<.1$ & $<.10$ & $<.01$ & $<.10$ & $<.1$ & $<.10$ & $<.01$ & $<.01$ & $<.01$ \\
\hline 380845097545101 & Reno & $<.1$ & $<.10$ & $<.01$ & $<.10$ & $<.1$ & $<.10$ & $<.01$ & $<.01$ & $<.01$ \\
\hline 380746097514802 & Reno & $<.1$ & $<.10$ & $<.01$ & $<.10$ & $<.1$ & $<.10$ & $<.01$ & $<.01$ & $<.01$ \\
\hline 380350097463301 & Reno & $<.1$ & $<.10$ & $<.01$ & $<.10$ & $<.1$ & $<.10$ & $<.01$ & $<.01$ & $<.01$ \\
\hline 375327098183401 & Reno & $<.1$ & $<.10$ & $<.01$ & $<.10$ & $<.1$ & $<.10$ & $<.01$ & $<.01$ & $<.01$ \\
\hline 380632098231401 & Reno & $<.1$ & $<.10$ & $<.01$ & $<.10$ & $<.1$ & $<.10$ & $<.01$ & $<.01$ & $<.01$ \\
\hline 381159098262101 & Rice & $<.1$ & $<.10$ & $<.01$ & $<.10$ & $<.1$ & $<.10$ & $<.01$ & $<.01$ & $<.01$ \\
\hline
\end{tabular}



